\title{
AFEHANISTAN
FORUA
}

EDNTENTS

May 1988

\section{VDL. XV1}

ND. 3

News Stories

Begin on page

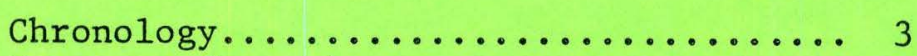

Excerpts from the Geneva Accord........ 11

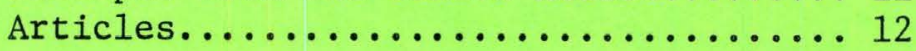

Organizations................... 2

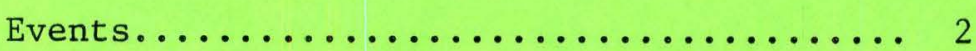

Educating Afghan Refugees in Iran....... 27

Recent Publications................ 29

Book Reviews.................... 30

Items from the Kabul New Times.......... 33

\section{AFEHANISTAN FORUM, JNE. टDI EAST T15T STREET. ZK NEWW YORK, NY LOOZl}




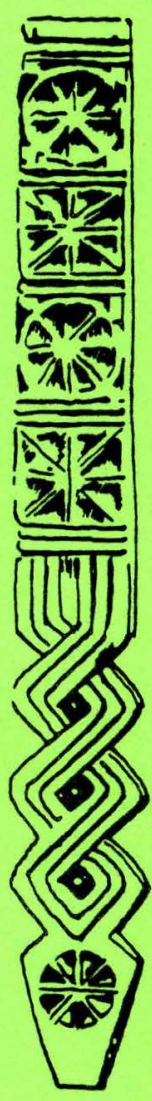

ABBREVIATIONS USED

AICMB - Afghan Information Center Monthly Bulletin
AWSJ - Asian Wall Street Journal
BIA - Bakhtar Information Agency
CC - Central Committee
CSM - Christian Science Monitor
DRA - Democratic Republic of Afghanistan
DYOA - Democratic Youth Organization of Afghanistan
FEER - Far Eastern Economic Review
FRG - Federal Republic of Germany
IHT - International Herald Tribune
KNT - Kabul New Times
NFF - National Fatherland Front
NWFP - Northwest Frontier Province
NYT - New York Times
NYCT - New York City Tribune
OIC - Organization of Islamic Conterence
PDPA - People's Democratic Party of Afghanistan
PSFO - Peace, Solidarity \& Friendship Organization
PT - Pakistan Times
ROA - Republic of Afghanistan
RTV - Refugee Tent Village
SCMP - South China Morning Post
UNGA - United Nations General Assembly
UNHCR - United Nations High Commission for Refugees
WDOA - Women's Democratic Organization of Afghanistan
WSJ - Wall Street Journal

Line drawing from the 1982 Afghanistan Calendar of the Chicago Afghanistan Relief Committee.

Please send items for the AFGHANISTAN FORUM to

The Afghanistan Forum, Inc.

201 East 7lst Street, 2K

New York, NY 10021, USA

The opinions expressed in the FORUM are those of the parties \& publications involved and are not necessarily those of the Afghanistan FORUM. Listing of organizations does not necessarily imply endorsement.

Mary Ann Siegfried

Editor \& typist
Leonard Oppenheim

Treasurer \& proofreader

Subscription rates: $\$ 20$ per year (US \& Canada) (Add $\$ 5$ for FORUM PAPERS)

6 issues/year

$\$ 24$ per year (foreign); airmail Europe - \$35; Asia $\$ 4 C$.

$\$ 35$ per year (institutions)

$\$ 45$;

$\$ 50$.

(includes FORUM PAPERS)

ISSN $\quad 0889-2148$ 
From the Editor:

After 6 years of negotiations, the Geneva agreements have been signed; Soviet troops will go home, to return, it is hoped, only as tourists. What remains to be done in Afghanistan, unfortunately, will make the Geneva talks seem like a fireside chat. The FORUM will continue to bring you all the news that fits with the hope that action will replace speculation so we can return to larger print. In the meantime, get out your lenses.

Recently we spoke to Yuri Gankovsky, the specialist on Afghanistan at the Soviet Inst. of Oriental Studies, part of the USSR Academy of Sciences in Moscow. Dr. Gankovsky, reportedly, was against the Soviet invasion of Afghanistan (being an historian) \& has been advising the Soviets to get their troops out of Afghanistan for a long time. He gave us the impression that he hoped they would never go back, regardless of what went on inside the country - but - he said it is impossible to guess what might happen.

He said that the USSR probably had only 12 real scholars on Afghan affairs, but dozens of "experts," statistics not unfamiliar here. He hopes the Afghans can get their act together without more bloodshed but he is not sanguine about the prospects.

He promised to send us an annotated bibliography of the books his Institute has published about Afghanistan. We'11 hope to have it for a future issue.

Our thanks to everyone who sent us clippings, cartoons \& news. Please continue. The deadline for the next issue is $6 / 15$.

\section{Transition}

. The only common prediction among officials at the State Department and intelligence agencies is that Najibullah, the Soviet-backed leader of Afghanistan, is unlikely to retain power for more than a year after the Soviet forces leave. Beyond that, there is ample speculation.

An official who studies Afghanistan for the United States Information Agency said the guerrilla commanders would want to hold on to the territory they now control, and, he said, "You might have continuous squabbles" among them. The United States wants to discourage such fragmentation. But having supported the guerrillas in their bloody eight-year struggle for self-determination, the United States is not about to impose its preferences on the country now, American officials said.

In accords signed this month, the United States and the Soviet Union agreed to refrain from interference in the internal affairs of Afghanistan. But as Soviet troops prepared to withdraw, Western diplomats in Pakistan reported last week that tons of Soviet supplies, including arms and ammunition, were still being flown into Kabul. And $\mathrm{Mr}$. Reagan declared, "We will continue to support the mujahedeen for as long as the Soviets support the Kabul regime." The rebel leaders, who did not sign the agreement, have vowed to fight to oust Mr. Najibullah.

The shape of any future Afghan government depends on whether it is formed through negotiation or more war, officials say. Diego Cordovez, the United Nations official who negotiated the agreements on Soviet withdrawal, has a mandate to help the Afghan people try to put together a government representing all elements of the Afghan nation. But there is no guarantee he will succeed, given the intense hostility between the Kabul Government and the mujahedeen.

Another possibility, according to American officials, is that the rebel leaders may put together a provisional government as a rival to the one in Kabul. They might set up such a government in another Afghan province, like Kandahar in the south or Paktia in the east, to conduct the next phase of the struggle, with the hope of eventually replacing the Government in Kabul, the officials said.

This alternative assumes that the guerrillas can forge a political structure of their own. If they cannot, the guerrilla commanders might go their separate ways, and the shape of the next government would then be determined by the outcome of the fighting between the Kabul Government and various rebe! groups. Finally, American officials said, there might be a coup in Kabul as the Soviets withdraw, and the leader of the coup could negotiate with the rebel leaders, regardless of whether they have formed a provisional government....

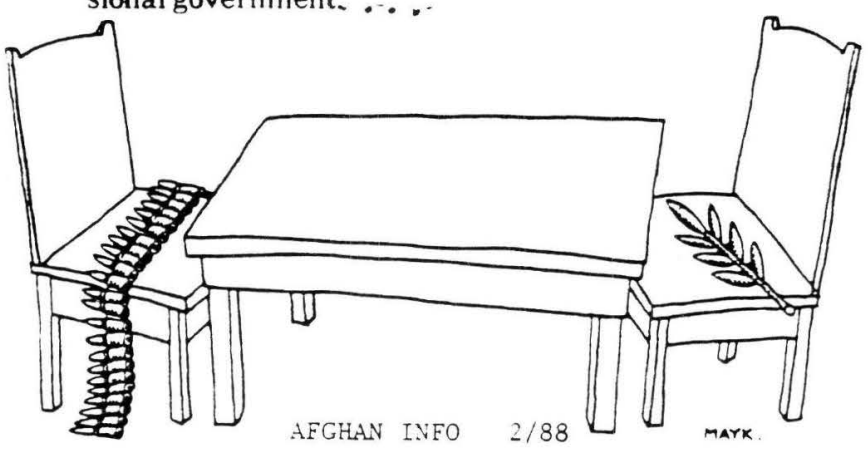


The AFGHAN ASSISTANCE COUNCIL, P.0. Box 162, Orinda, CA 94563, founded last year, has written to Pres. Reagan expressing its concern over the possibility of the US ending its support to the mujahideen and calling attention to several other issues: 1) The return of the Wakhan Corridor. 2) The return of over 50,000 Afghan children from the USSR. 3) The withdrawal of Soviet \& East European civilian personnel from all advisory positions. 4) The revocation of bilateral treaties on political, territorial \& military issues concluded between the USSR or other communist countries - and the Kabul regimes since $4 / 26 / 78$. The renegotiation of commercial \& economic treaties concluded during the same period. 5) The return of all military installations \& bases established after the Soviet invasion, to the gov't of free Afghanistan. 7) Guarantees of future Soviet non-interference in Afghanistan's internal \& external affairs, countersigned by Afghanistan's neighbors \& by the permanent members of the UN Security Council. Board members of the organization are M.S. Noorzoy, R. Farhadi, P. M. Koshani, Y.M. Mojaddedi, Q. Kochai $\&$ A.H. Hamid. The Council also wrote a 21 point set of conditions \& demands for a peace settlement with the Soviets, to be presented to them after the current Kabul regime is eliminated. The document was presented to the Peshawar Alliance and was adopted by the Alliance for implementation at the proper time.

FREEDOM MEDICINE publishes DISPATCHES, a bi-monthly sheet describing its activities, 1isting items the organization needs, and carrying articles by some of its personnel. The organization has medical clinics and paramedic teaching facilities in Pakistan near the Afghan border. For a copy of DISPATCHES - or to make a contribution, write them at 941 River Street, Suite 240, Honolulu, Hawaii 96817.

The SOCIETY OF AFGHANS RESIDENT IN THE U.K. opened a school last December. About 40 children are learning Pushto, Dari, mathematics \& religion. The Society has also printed some textbooks. For information on the plight of Afghan

refugees in Britain, subscribe to the quarterly Newsletter of the AFGHAN REFUGEE INFORMATION NETWORK (ARIN), 77, Chelverton Road, London, SW15 1RW, United Kingdom. Subscriptions in the US are $\alpha^{r} 7 /$ year.

\section{EUENTS}

Cellist/composer David Darling will play a benefit concert for the AFGHAN REFUGEE FUND at 8 p.m. on $5 / 28$ at St. Peter's Lutheran Church (Lexington Ave d 54th St. NYC), Tickets are $\$ 15$; call (212)873-7761 for reservations.

AFGHANISTAN: IMPLICATIONS \& RAMIFICATIONS OF SOVIET WITHDRAWAL was the title of a discussion at Duke University on $4 / 6$. Participating were Nazif Shahrani, "Politics in Afghanistan"; Robert Canfield, "Religion in Afghanistan"; Farhad Kazemi, "Politics in Iran"; Robert Wirsing, "India \& Pakistan" \& Alex Alexiev, "USSR." Louis Dupree chaired the session.

\section{AAS NEW ENGLAND CONFERENCE}

The 1988 anmual meeting of the New England Conterence of the AAS will be held October 29. 1900 at Weeloyan Univerelty. Paper and panel proposels of ons or two paragraphe are reqeeted. Organizers hops to accomodate indlutitual papers, but prefer contributors to work up their own panets of four people (three papers and one discuseamt, or four papers and a moderator). The Program Chair is Ellen Widmer, Department of Asian Languages and Literatures, Wesibyan University; phone 203-347-9411, oxt. 3157. The contact person, however, is Shirley Lawrence. Freeman Center for East Astan Studles. Department of Asian Languages and Literatures. Flak Hall. Wealoyan University, Middilelown, CT 08457; phone 203-347-9411, oxt. 3152.

\section{AAS NEW YOAK CONFEAENCE}

The annual meeting of the New Yoik Conference of the AAS will bo held October 7-9, 1906 at the State University of New York, Albany. The Conterences co-chelrs are DoWmet Ellimmood, Department of History, SUNY, Albeny; Hsin-sheng Kao, Chinese Studlee. SUNY at Albany; and Shahid Retal, Hatory Department, College of St. Rose. Other members of the Stecering Cornmittee are Steven Lelbo. Hatory Departinem, Ruenew Sege Collepe, and Won Yoon. History. Slena College. Pand and indulutual paper proposala should be semt to DoWm Elinmood, Depertment of History 518 . SUNY at Albany, Albany, NY. 12222: phons 510-42-4793 bofore the June 1 deediline. AAS SOUTHMET CONPEAENCE

The 1988 meeting of the MS Soutmuen Conterence will be held at North Toxas Siate Univeralty, Denton. Toxas, October 28-29. 1988. The Program Chair is Donald N. Clark, Department of History, Trinity University, San Amtonio. TX 28284. The Local Arrangements Chair is Robert Detrick, Depertment of History, North Texas Stato University, Denton, TX 78203; phone 817-565-2288. CONFEAEACE ON SOUTH ASIA

The 17 th Annual Conterences on South Aela will be held Novernber 4-6, 1988 at the Untvereity of Wheconsin, Madison. This internethonal evert, which is eponsoored by the university's South Acla Conter is the only annual conterences in the US dealing oxctuetrely with the Indian Subcontineme. Propoeale with abstracts should bo submitred on offictal prooosed forme by May 1, 1988. For details. contact Conference Coordinator. South Asian Area Center Conference Office. 1236 Van Hiso Hail. University of Wisconsin. Madison. WI 53706; phone 608-282-3384
ASPAC Conterenco Cail Stato University Northridge. Calliomia June 24-28, 1989

Ram M. Roy'

Depart of Pollitical Science Call State Univ-Northridge Northridge, CA 91330

Mid-Attantic Conterence Indiana University of Pennsylvania Indlana. Pennsylvania October 21-23, 1988

Robert Gardella Dept of Humanitles US Merchant Mart ne Academy KIngs Poimt, NY 11024

Mictweat Conference University of Weconsin Madison. Wisconsin Seotember 23-25, 1988

Ectward Friedman" East Asia Studies 1440 Van Hise 1220 Linden Dive Medison, Wisconsin 53708

Western Conference University of Washington Seattle, Wasinington Date to be announced Frank Conlon" History Department University of Wesnington Seattle. WA 98195

- Program Chair 
2/20 - BIA - ROA Foreign Minister Abdul Wakil returned from his visit to Kuwait, Libya, Syria \& Jordan.

$2 / 21$ - BIA - A protocol of cooperation between The Georgian SSR \& Kapisa Province was signed. The Georgians will train Afghan cadres in the agricultural, health, light industries \& educational fields.

- The two huge statues of Buddha in Bamyan are "still firmly standing in their places despite hundreds of natural disasters, such as earthquakes, floods, storms, etc."

2/24 - Los Angeles Times - The 7-Party Alliance in Peshawar proposed a coalition gov't with a 28-member cabinet of 14 ministers from the Alliance, 7 representing the refugees \& 7 Muslims from the Kabul regime (see p. 14).

$2 / 25$ - BIA - On the Islamic Alliance's plan for an interim gov't (see 2/24):

"Such futile design \& desperate strivings...run counter to any moral \& legal principles \& are resembling hysteric dreams."

- The Chairman of the State Committee for Returnees met with a delegation of the UN High Commissioner for Refugees in Kabul at the invitation of the ROA Foreign Ministry to talk on the "provision of aids for the refugees."

- Since 1/87, over 1,100 emigre Afghans have returned from India, Japan, England, the FRG, Turkey, France, Switzerland, the US \& Austria.

2/26 - LA Times - The Reagan Administration predicted that the current Kabul regime will collapse after the Soviet withdrawal. A Defense Dept. official said that Soviet troops will probably leave from southern \& western Afghanistan lst, \& then from areas south \& east of Kabul. He said that Afghanistan has about 40,000 regular army troops, 7,000 air force members \& another 100,000 irregulars, "including tribal militia of uncertain loyalty." The Kabul regime will remain well armed.

$2 / 28$ - LA Times - India says the US asked her to take an active role in the peace talks. Rajiv Gandhi has invited Zia ul-Haq to Delhi to discuss the Afghan issue but Zia has yet to respond.
2/28 - BIA - The UNHCR delegation (see 2/25) visited Herat. On $3 / 1$ BIA reported that they also visited Torkham \& other villages in Nangarhar Province.

$3 / 1$ - The Outlook (Santa Monica) - The US Senate yesterday voted 77-0 on a "non-binding resolution to warn the Reagan Adm. not to end US military aid to the mujahideen before a Soviet withdrawal of all troops \& advisors was complete. The resolution also gave strong support for the formation of an interim gov't in Kabul \& for a UN peacekeeping force to protect withdrawing Soviet troops from attack \& to keep the peace in major cities while an interim gov't is being organized.

$3 / 2$ - NYT - The State Dept. said the opium supp1y from Afghanistan in 1986 was 400-500 metric tons, \& increased to 400-800 metric tons in 1987. Hashish exports remained constant at 200-400 metric tons. Pres. Reagan announced "mostly symbolic" penalties against some drug producing countries including Afghanistan.

$3 / 3$ - LA Times - The Geneva talks began yesterday. On 3/1 Pak. Dep. For. Min. Zain

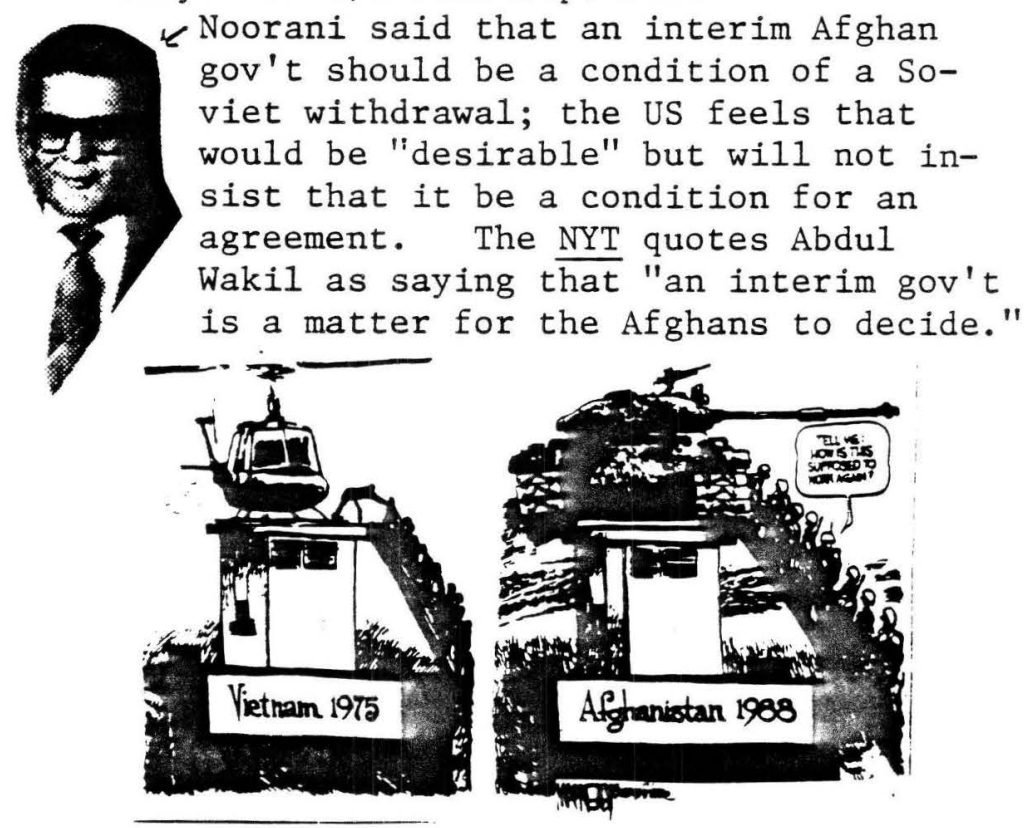

- MI - The UN has drawn up plans to send about 40 military observers to Afghanistan \& Pakistan in May to monitor a peace agreement. The officers will be drawn from the UN Truce Supervisory Organization, a 298-member force now monitoring cease-fire agreements between Israel \& its Arab neighbors. - BIA - A school is to be built in the Kirghiz SSR for the children of martyrs of the April 
Revolution from Wardak \& Bamyan. Presently 100 such children are being taught by Afghan teachers in the Kirghiz city of Kand.

- The Byelorussian SSR will help

Kunar \& Laghman in the fields of education, communications, agriculture, land reform, public health \& trade unions. The 797,000 rubles worth of aid will start in 1989.

$3 / 4$ - LA Times At Geneva, the Soviet pullout timetable was shortened to 9 months with $\frac{1}{2}$ of the 115,000 troops scheduled to leave in the lst 3 months, according to ROA Foreign Minister Wakil. - NYT - Wakil said Kabul was ready to start talks on a new gov't after a peace settlement was signed

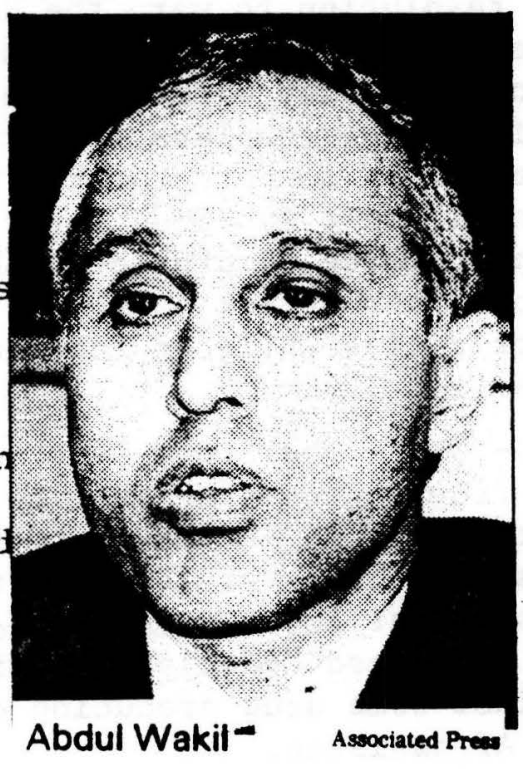
but he warned that such power.-sharing negotiations could take a long time.

$3 / 5$ - BIA- In a clash between the groups of Gulbuddin \& Khalis, 2 French citizens $\&$ some "extremist elements" were killed.

3/5 - Kayhan Int'1 (Tehran) - Iranian Dep. Foreign Min. Larijana called for an unconditional Soviet pullout from Afghanistan \& said that the mujahideen would not stop fighting until the Soviets left. He said that Iran would help the Afghan people get their rights.

- LA Times - US officials assured the mujahideen that their weapon supply would continue \& perhaps increase until 5/15.

...Many of the guerrillas, after present and not represented. eight years of fighting against "We want to be there to collect Soviet and Afghan government the fruits of our resistance," said troops, fear that their effort will be Sebratullah Mojadidi, a leader with traded away in a foreign confer- the moderate Afghanistan National ence room where they are not Liberation Front...

- The UN Commission on Human Rights, in

a report issued on $3 / 3$, concluded that only a representative interim gov't could ensure the orderly return of refugees. While Diego Cordovez admitted that civil strife has always been a part of Afghan life, he said that now "I have the feeling they want peace," \& that the question of a gov't "cannot be part of an int' 1 agreement."

$3 / 6$ - LA Times - Senator Gordon Humphrey $(R-N H)$ said, $_{3}$ after a visit to Pakistan, that there had been a sharp decline in the flow of US aid to the mujahideen. "I want to know if this is negligence or a sellout of the Afghan resistance," he said. Meanwhile, Pravda charged that the rebels are moving large quantities of weapons into Afghanistan. - BIA - The traditional Red Rose Picnic in Mazar-i-Sharif will begin on $3 / 21$ \& last 40 days. The city will be illuminated; there will be art exhibits, sports shows \& buzkashi.

\section{$3 / 7$ - HK Standard - Pakistani Prime Minister} Junejo held sessions allowing all 19 Pakistani opposition parties to give their views on whether Pakistan should sign a Geneva agreement. Benazir Bhutto gave the strongest plea for an early settlement.

\section{$3 / 8$ - BIA - The ROA \& USSR signed a protocol} on the "consolidation of the Amu (Oxus) River shores \& the erection of a protective wall in the Hairatan Port." The USSR will give a ruble $15 \mathrm{~m}$ loan for the "concretization."

\section{3/9 - NYT - Sibghatullah Mojaddedi resigned}

from the 7-Party Alliance \& as leader of the Jabha-i-Nijat-i-Milli Party yesterday. He said he resisted the urging of the 4 fundamentalist parties to announce an intcrim gov't headed by Ahmad Shah.

$3 / 11$ - NYT - Last week the US said it would not stop aiding the Afghan guerrillas unless Moscow agreed to stop sending military supplies to the ROA. The Soviets said they would not stop \& accused the US of holding up the Geneva agreement. Nokolai Kozyrev who heads a Soviet team monitoring the indirect talks said that such a suggestion was outside the Geneva accord. (See 3/13)

$3 / 13$ - Sydney íorning Herald (Australia) -

\begin{abstract}
-We have been rendering military assistance to this country for more than 70 years and to many governments, not just the present one," the Soviet Ambassador, Mr Nikolai Kozyrev, told a news conference.

"The question of ending military aid to Afghanistan is to interfere with the internal affairs between our two countries. It is tantamount to our saying the United States should stop its military aid to Pakistan."
\end{abstract}

- Mojaddedi withdrew his resignations (see 3/9) after appeals from his party members \& other members of the Alliance. 
$3 / 13$ - NYT - In Geneva, officials see little chance of a $3 / 15$ signing of the peace accord but officials say that Moscow \& Kabul may no longer insist on a 60-day interval between the signing \& the start of the pullout. Moscow may want the withdrawal to start before Reagan \& Gorbachev meet in late May \& before the Soviet Communist Party Congress in June.

- Soviet army defectors in Afghanistan sent telegrams to Geneva negotiators urging that Soviet prisoners in Afghanistan be given the choice of returning to the USSR or going to a

"free country."

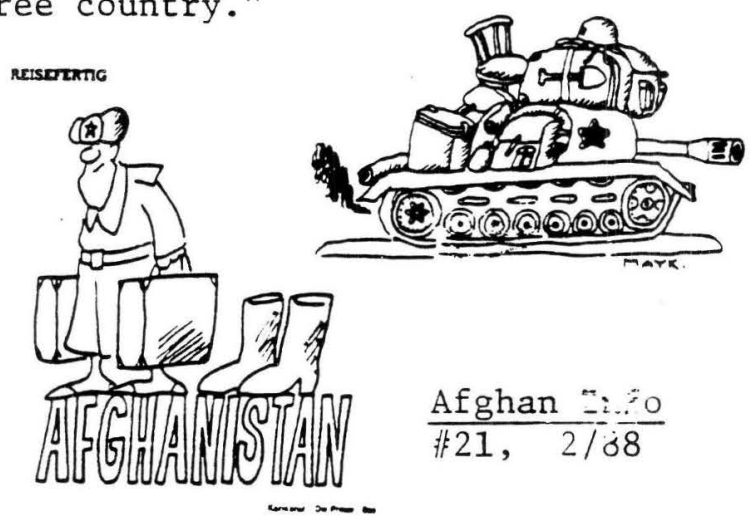

3/14 - TIME - Mujahideen say CIA arms shipments to them via Pakistan have declined 50\% over the past 2 months, and Last $\mathrm{De}^{-}$

cember the U.S. shipped almost the anımals have not adjusted 2,000 Tennessee mules to Paki- to their new climate. Some stan to carry rebel supplies have died, others have develacross the border. However, oped conjunctivitis, and many Pakistani sources say many of are just too wobbly to work.

KNT - The 1st issue of Adalat (Justice), the monthly organ of the Peasant's Justice Party of Afghanistan, appeared last week. Abdul Hakim Tawana is the Party Chairman.

3/15 - HK Standard - The 7-Party Alliance met yesterday to try to find a new leader after the resignation of Yunis Khalis. (See 3/17)

- Najibullah set up a council to advise him on Islamic Affairs.

$3 / 16$ - NYT - The USSR said it was postponing its troop withdrawal because of "procrastination \& delay" by Pakistan \& the US.

- BIA - "Any case of AIDS has not yet been registered in Afghanistan but the Public Health Min., with WHO assistance, has taken all precautionary measures to prevent AIDS in the country."

3/17 - HK Standard - Gulbuddin Hekmatyar was chosen Chairman of the Alliance on $3 / 15$. [Rumor has it that Pakistan had a strong hand in his election. Ed]

- NYT - Zain Noorani said that Shultz \& Shevardnadze could play a role in unblocking the Geneva talks when they meet next week by agreeing on a "symmetrical" cutoff in

military aid.

Mr. Noorani said at a news conference today that the Afghan insurgents control 80 percent of Afghanistan and that they are the true representatives of the Afghan people.

The Pakistani negotiator made clear that his Government would sign .a peace agreement only if all Afghan political factions agreed to talks on forming a Government. The new Government would take power once the Soviet forces withdrew. He said that the various Afghan factions must agree to continue talking even after a peace accord comes into force.

Mr. Noorani insisted that Pakistan was not making the prior formation of such a Government "a precondition" for the signing a peace agreement.

He said Pakistan wanted representatives of all the factions in Afghan political life, including "refugees, resistance fighters, émigrés and representatives of the present regime," to come together in Geneva, Vienna or elsewhere and start to form a new Government
$3 / 18$ - SCMP - The USSR will withdraw its troops from Afghanistan, Geneva agreement of not, but it still hopes for a settlement.

$3 / 18$ - BIA - The RC approved the draft of the Law on Elections ( 8 chapters, 58 articles), next year's budget, \& friendship \& cooperation treaties with Vietnam \& Kampuchea. Najibullah issued a decree on the formation \& composition of a central election commission. NF Chairman Abdul Rahim Latif will chair the 33-member group which is to supervise the election for National Assembly members. Deputy Chairmen are Mir Saheb Karwal, Revolutionary Org. of the Working People of Afghanistan (ROWPA); Dr. Dehzad, Working People of Afghanistan (OWPA); Abdul Hakim Tawana, Peasant's Justice Party; Abdul Sattar Serat, Islamic Party. 9 places on the commission will be left vacant for "opposition" representatives. ( See 3/19)

3/19 - BIA - The Afghan Nat'1 Assemb1y will consist of 2 houses: the Senate \& the House of Representatives. Candidates can be put forward by the NF, the political parties, social organizations and the President.

Terms are 5 years. House candidates must be at least 20; Senatorial candidates at least 30. A11 Afghan citizens over 18, except prisoners \& madmen, may vote. Polls will be open from $7 \mathrm{a} . \mathrm{m}$. to $7 \mathrm{p} . \mathrm{m}$. \& the results will be published 7 days after the elections. (See 3/21.) 
3/19 - HK Standard - Singapore Pres. Lee Kwan Yew, visiting Pakistan, said that progress toward ending the Afghan conflict would have a "positive impact" for resolving the kampuchean problem.

3/20 - BIA - Sultan Ali Keshtmand spoke at the inauguration of Balkh University.

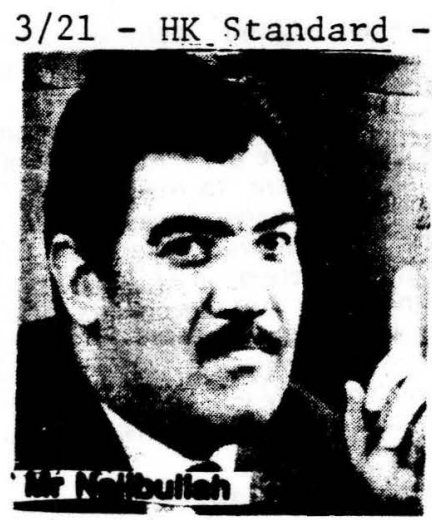

- Najibullah has called for elections from 4/615. 229 seats in the Council of Reps. \& 62 seats in the Council of Elders will be contested. Some seats will be kept vacant for the rebels if they fail to run for office now. Najibullah will process all nominations.

A Hezb-i-Islami spokesman said the elections were "another trick to deceive the (Afghan) people \& world opinion."

- NYT - Soviet For. Min. Shevardnadze arrived in Washington for a round of discussions that will include Afghanistan.

3/22- NY Newsday - Pres. Reagan proclaimed "Afghanistan Day" yesterday at a White House ceremony.

- BIA - 120,787 people have availed themselves of Nat'1 Reconciliation; 63,634 from Pakistan, 55,966 from Iran \& the rest from other countries (see $2 / 25$ ).

\section{$3 / 23$ - NYT - The Durrand Line at Geneva:}

But officials say agreement on a fifth between the guerrillas and their beckinstrument, offering Afghanistan guar- ers.inPakistan.

antees against outside interference in Kabul's move has angered the Soviet its internal affairs, has been blocked by Union, according to officials here, Kabul's unexpected decision late last which sees as another attempt to delay week to raise an old colonial border dis- which sees as another attempt to delay pute with Pakistan, apparently in defiance of Moscow's wishes.

The dispute concerns the so-called Durran Line, a boundary drawn in 1893 between what was then British India and Afghanistan and which the Afghans have never accepted. The frontier line alvides the pusntan irioal area, which Afghanistan claims.

By reviving the dispute now, officials say Kabul has raised an emotional issue in Afghanistan that is likely to unite all Afghans including Commudraw its forces. It has also angered Pakistan's chief negotiator, Deputy Foreign Minister Zain Noorani, who maintains his country has no border dispute at all with Afghanistan.

But officials say that Under Secretarv General Cordovez is forced to take Kabul's objection seriously because it effectively calls into question references to Afghanistan's "internation"ally recognized frontiers" contained in the draft agreement on outside interference.

\section{$3 / 24$ - BIA on the Durrand Line issue: "The State \\ of the ROA decisively condemns the isșue \& regards it as another pretext of the Pakistani side bring- ing the talks to a standstill." \\ - SCMP - Signs of a Soviet pullout:}

- Afghan Government

- Soviet civilians in the capital of Kabul were being relocated to newer, more easily defensible buildings near the Soviet embassy.
- All members of the Khad, the Afghan secret police, had their leave cancelled and were to return to ctive duty, the reports said.

"Soviet authorities in Af- ghanistan have begun an inventory of 204 Soviet military and civilian installations with a view to transferring some equipment to the regime, along with the facilities," the reports added.

3/24 - BIA - The Politburo discussed the establishment of a new province, the former district of Sar-e-Pul, in the southern areas of Balkh \& Jauzjan. State organs were instructed to set up elections, make appointments \& establish social organizations in the new province. (See 4/1)

$3 / 25$ - SCMP - Sec'y Shultz offered a compromise to Shevardnadze whereby Soviet aid to the ROA would be cut off for only a year, starting at the beginning of the troop pullout. The US would stop aiding the mujahideen during that year. Shevardnadze rejected the idea declaring that Soviet deliveries were legitimate since they were based on a bi-lateral treaty. "We have had this sort of relationship with Afghanistan since 1921," he said.

- LA Times - The US, Pakistan \& the USSR will "paper over" their differences on the makeup of an interim gov't in Afghanistan, leaving military aid the only hitch.

$3 / 26$ - HK Standard - Pakistan is willing for the Soviets to withdraw while Diego Cordovez consults with the warring

factions on the formation of an interim ov't in Afghanistan.

\begin{tabular}{l}
\hline dullah Jaffa \\
Bey Khan in \\
Seattle in \\
1930, the \\
son of an Af- \\
ghan res- \\
taurant \\
owner \& his \\
Italian wife, \\
died yes- \\
terday in \\
New York, \\
He was the \\
founder \& \\
artistic \\
director of \\
the Joffrey
\end{tabular}


$3 / 26$ - BIA - The PDPA, ROWPA \& OWPA (see $3 / 18$ ) have formed the Left-Wing Democratic Parties Alliance of Afghanistan. The Alliance's leading body is the Coordinating Council on which each party has a representative.

$3 / 27$ - The Daily Breeze (Santa Monica)The US State Dept. was close to proposing a halt in covert US military aid to the mujahideen but Reagan rejected the idea. The Administration is ending its Stinger shipments but is rushing $\$ 300 \mathrm{~m}$ worth of other equipment, including $120 \mathrm{~mm}$ Spanish heavy mortars. Dep. Asst. Sec'y of State Robert Peck said the US will continue its assistance to the mujahideen "until it is no longer needed. There have been no secret deals. No deals at a11."

$3 / 28$ - The ROA \& Bulgarian Chambers of Commerce signed a cooperation protocol in which Bulgaria will help the ROA establish some medium \& small indistries.

$3 / 29$ - BIA - "Following the visit of Burhanuddin Rabbani to Iran the extremist leaders have recently sent their representatives to... Iran... The extremist leaders have gifted 12 Stingers to the Iranian leaders. This has not been confirmed so far by other sources."

- Najibullah called upon Masood, Mullah Nasim (Helmand), Capt. Ismail (Herat), Sayed Jaglan (Ghazni), Frarid [sic] (Kapisa), Jalaluddin Haqani (Zadran), Basir Khaled (Badakhshan) \& all other opposition commanders to participate in the national elections. $25 \%$ of the seats will be held for the opposition. "We are prepared to consider your proposals on forming a coalition gov't. Don't miss this historic chance." - NYT - A car bomb exploded in Kabul killing 5 people. At least 5 other bombs have exploded there during the past week. On $3 / 30$ it was reported that Saleh Moh'd Zeary, a senior Politburo member, was slightly injured in 1 of the blasts.

3/31 - NYT - The USSR hinted that it would consider allowing US military aid to reach the guerrillas after the cutoff date set in the Geneva agreement.
3/31 - SCMP - Ahmad Shah, designated head of the $\overline{7-P a r t y ~ A l l i a n c e ~ i n t e r i m ~ g o v ' t, ~ s a i d ~}$ the Alliance would form its gov't in the mountains bordering Afghanistan. A 14-member cabinet will be named within 90 days \& will consist of 2 reps. from each of the 7

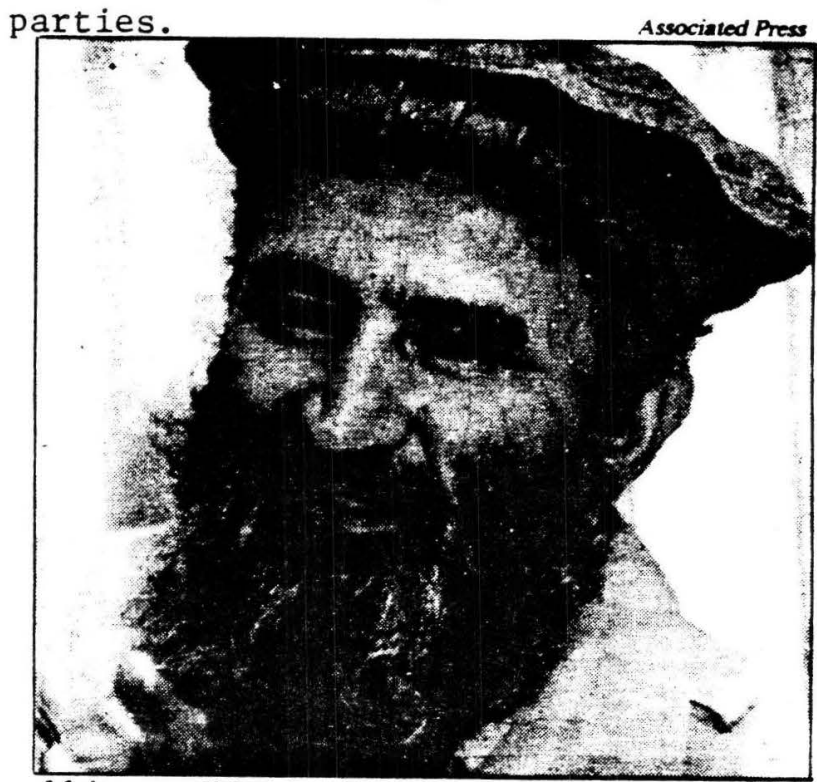

Afghan coalition leader Ahmad Shah

- Najibullah offered the rebels the posts of Prime Minister \& Vice President. He said the ROA could implement the rebel proposal for a coalition gov't.

4/1 - BIA - Najibullah stated that the PDPA was not a communist party \& "our revolution is not a socialist revolution. The April Revolution is a nat' 1 \& democratic revolution... Time has changed \& is changing the forms \& period of the realization of the objectives of our revolution." "The 400,000 strong Afghan armed forces will be able to defend the gains of the revolution provided interference from abroad is caused [sic]." The PDPA does not want to guide the coalition gov't but it will take part through its representatives.

- NYT - Sar-e-Pul, the new Afghan province (see 3/24) could serve as a stronghold for Soviet forces \& be used to reassure the PDPA

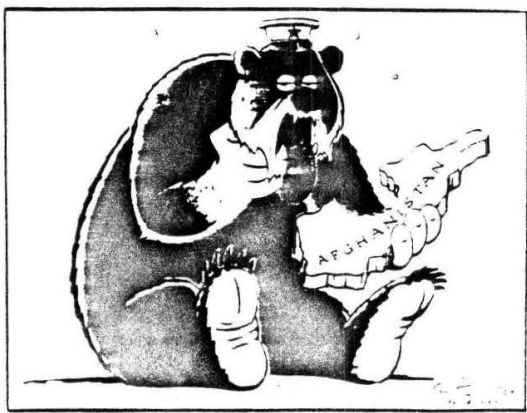

Soldier of Fortune $4 / 88$ that Moscow will not desert its ally. It will increase the number of seats in parliament $\& /$ or insulate the Muslim Central Asian republics from any Afghan fundamentalist influences. Experts also say that the 
province will leave the flat northern portions of Balkh \& Jauzjan with a defensible southern frontier against the rest of Afghanistan. Mazar-i-Sharif will be the main city of the new province.

- LA Times - A tentative agreement has been reached in Geneva but the arms supply dispute still threatens it. State Dept. \& White House officials said the US is following a policy of "symmetry \& balance" \& that the US will continue its support of the mujahideen as long as the Soviets continue theirs of the Kabul Gov't.

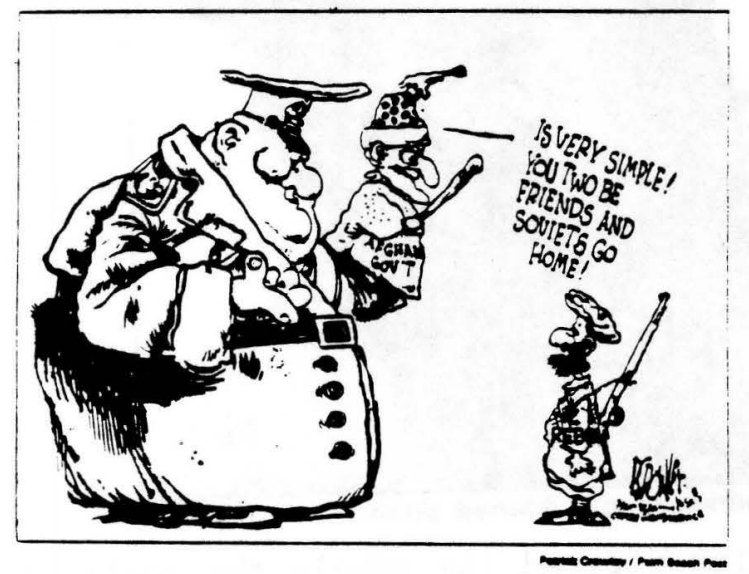

4/3 - LA Times - The Soviet Amb. at Large Nikolai Kozyrev suggested that the Geneva agreements be signed without the US. Afghanistan \& Pakistan would sign documents covering noninterference in each other's affairs \& the return of the refugees. Moscow would sign the troop withdrawal document \& the US would be dropped as a guarantor.

- Gulbuddin said the mujahideen would continue to fight the Kabul Gov't if the UNmediated agreement is signed in its present form. An agreement that fails to set up an interim gov't \& stop military aid to Kabul is unacceptable to the Alliance.

- BIA - Gorjistan Magazine, the organ of the Central Council of Hazara Nationality, recently made its debut.

4/4 - LA Times - Soviet For. Min. Shevardnadze flew to Kabul to discuss what to do if the Geneva talks fail. Diego Cordovez proposed writing a memorandum recording the US intention of cutting aid to the rebels only as long as Moscow curtailed its weapons' supply to the ROA. The USSR would not stop the supply but would recognize that she took a risk in continuing.
4/4 - The Outlook - The US has stopped supplying Stingers to the mujahideen (see pp. 18, 20, 21).

$4 / 5$ - BIA - Voting began in the ROA. A photo \& biography were attached to each candidate's box (see 3/21).

- NYT - US officials reported that the USSR seems to be preparing to withdraw its troops. Some units in exposed positions have already been pulled back. - LA Times - Senator Humphrey said he thought the US was too optimistic in thinking the Kabul regime would fall in a matter of weeks. He thinks it may take over a year.

4/6 - NYT - At Geneva "negative symmetry," the joint ban on military supplies, may be replaced with "positive symmetry," continued arms supply. Positive symmetry might be ok with the US if it provided for "balanced, reciprocal obligations" on both sides.

- LA Times - More on the ROA elections: a third of the Upper House seats will be filled by presidential appointment, a third chosen by Provisional Councils \& a third elected over the next 10 days.

4/7 - NYT - Mikhail Gorbachev flew to Tashkent to meet with Najibullah \& Shevardnadze. (See p.18)

- Senator Humphrey called the Geneva documents "fundamentally flawed." He said that as it stands Pakistan would be violating the treaty if she allowed the US to continue supplying weapons.

4/8 - NYT - A 9-month suspension of all arms deliveries will go into effect at the conclusion of the troop withdrawal agreement. Both Moscow \& Washington reserve the right to resume military supply if one side breaks the informal agreement.

4/9 - NYT - Full agreement on a 4-part treaty for the Soviet withdrawal from Afghanistan was reached in Geneva yesterday. (See 4/15)

4/10 - NYT - Gulbuddin said the mujahideen will not be bound by the Geneva agreement:

"No agreements can be implemented in Afghanistan without the consent of the mujahedeen," the guerrilla leader warned. He said a Geneva agreement could not "terminate the war, nor can it result in the voluntary return of the refugees." 
4/11 - LA Times - Yesterday Afghan guerrillas shot down an AN-26 airplane carrying passengers from Maimana to Mazar-iSharif. All 29 people aboard were killed. - Explosions yesterday in an ammunition dump near Islamabad killed at least 75 \& injured hundreds (see $4 / 12,15$ ).

- Najibullah sent a sympathy message to Zia ul-Haq for the "sad incident" of the ammunition dump explosion.

4/12 - NYT - Reagan Administration officials said that weapons for the mujahideen may have been destroyed in the Islamabad explosion but that there were "plenty more" weapons in the pipeline (So far 93 have died \& 1,100 have been injured.) Pres. Zia said that the claim that guerrilla weapons were at the depot was

"mere speculation." (See 4/15)

- The US \& Moscow agreed on the Geneva accords:

Under the accords, Pakistan pleages "noninterference" in Afghanistan's internal affairs. But unless Moscow stops aiding the Kabul regime, Administration officials say they have been assured that Pakistan will remain a conduit for aid to the Afghan guerrillas.

$\mathrm{Mr}$. Shultz declined to comment on how Washington would respond if Moscow charges Pakistan with violating the terms of the accords.

"I'm not going to step in that hole," Mr. Shultz said.

The accord permits continued American aid to the Afghan guerrillas so long as Moscow provides such assistance to the Kabul Government.

"I believe that the U.S. can now join

4/14 - NYT - The poppies are blooming along the Pakistan-Afghanistan border. Estimates of Afghan production range from 500-1,000 tons. Growers get $\$ 60-130 /$ kilo. (See 3/2).

4/15 - BIA - 1,547,000 people voted in the ROA elections \& winners will be announced shortly. Najibullah said, "It will not be deplorable for those who did not win as they will use their experience \& knowledge in other spheres of life." 5 political parties, 9 social organizations, \& opposition candidates proposed candidates; "70\% of the candidates nominated themselves." However, in some opposition-held areas, elections were not held.

- NYT - The Geneva accords were signed by US State Sec'y Shultz, Soviet For. Min. Shevardnadze, Pakistan Acting For. Min. Zain Noorani \& ROA For. Min. Abdul Wakil (see p. 11).

- 7ia ul-Haq said he believed the ammuni-

the soviet union as a guarantor of the Geneva instruments," President Reagan said in declaring Washington's acceptance of the accord.

\section{Promise of 'Continued Support'}

"This development would not have been possible had it not been for the valiant struggle of the Afghan people to rid their country of foreign occupa. tion," he said. "We take great pride in having assisted the Afghan people in this triumph and they can count on our continued support." . •

Senator Humphrey denounced the agreement as a "slow-motion sellout" of the Afghan resistance.

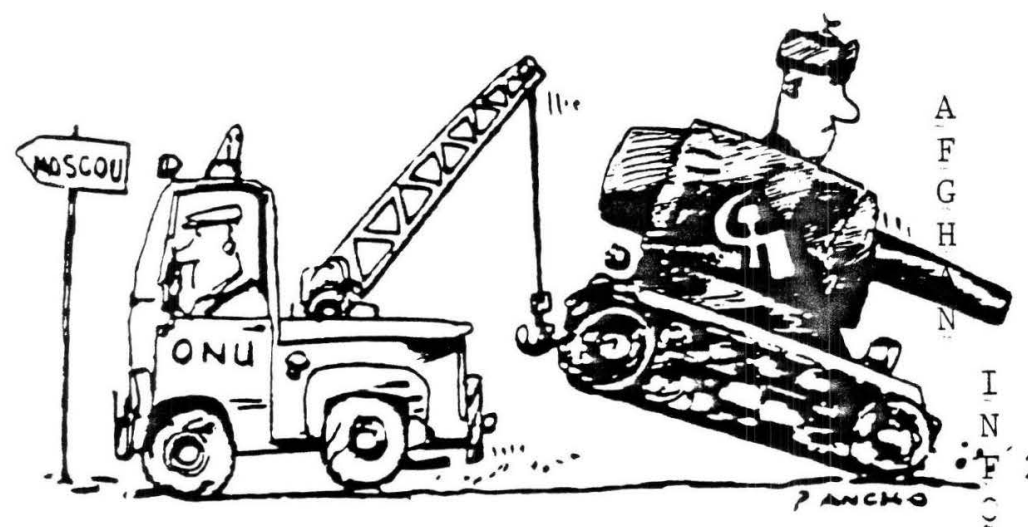

- BIA - Afs. "1 thousand 100 million" will be spent to repair reservoirs \& underground canals this year.

- Gen. Shah Aga was injured in an "extremist attack" while on his way to Kabul from Pul-eMatak. He died in a hospital shortly thereafter.

$4 / 13$ - The Outlook - There has been a sharp increase in military activity in Eastern Afghanistan during the past 2 weeks as spring thaws have opened the mountain supply routes. 
4/17 - NYT - US Defense Dept. officials believe that Kabul agents were involved in the ammunition dump explosion in Islamabad (see 4/11). The "overwhelming majority" of the weapons there was intended for the mujahideen \& included a third of the total supply of Stingers, anti-tank missiles \& long-range mortars - LA Times - Najibullah said he is prepared to "redeploy" ROA troops away from villages to encourage the return of the refugees. He also said the ROA was prepared to arm the tribes in the frontier so they can provide their own security.

- At a rally in Peshawar, Gulbuddin asked for a show of hands of those who would wait until the last Soviet soldie went home before returning to Afghanistan; virtually all hands went up.

4/23 - NYT - In Kunar, Barikot fell to the mujahideen after a 4-month siege. The garrison was the headquarters of the 55 th ROA brigade but 5 battallions were airlifted out before the mujahideen over-ran the base. Its capture will ease the transport of supplies over the border.

4/25 - NYT - Mujahideen have occupied Athgar in Zabul Province \& Maruf in Kandahar Province after the towns were abandoned by ROA troops.

- Najibullah described the guerrilla occupation of Barikot (see 4/23) as a "change of position." He also said he wants better relations with the US but first, Washington must stop sending military aid to Pakistan. He said the ROA is hoping to seek private investment from the US.

$4 / 26$ - NYT - Najibullah offered to create a demilitarized zone for Afghan refugees to pass through as Soviet troops are withdrawn. The ROA might even withdraw its troops further, if necessary. However, some say this is only to put a good face on defeat since major ROA withdrawals have come only after battles with the mujahideen.

\footnotetext{
"Things are happening a little faster than we anticipated," an American dip. lomat said. The guerrillas were ex. pected to close roads first, he said, bui 'they seem to have skipped that step' and have moved directly to attacks on bases and towns.
}

Within the past week, the guerrula: ing their forces and departing from the also took the town of Maruf, east of southeastern Zabul Province. The pull Kandahar, near the Pakistani border out from Qalat, which is Zabul's Earlier this month, they seized Ghor provincial center, took place about band, a district center about 50 miles April 18; according to a traveler's renorthwest of Kabul, cutting the mair. port reaching a Western embassy.

east-west road between Bamian anc Parwan Provinces.

In March, the guerrillas took Panj uai, a district center in Kandahar Prov ince, after a fierce battle. And Darwaz gai, another base that controls access to roads from the Pakistani border also fell to the guerrillas after a harc fight, diplomats report.

Damaged armored vehicles are alse being transported on flatbed trailers north into the Soviet Union, accordink to Western reports.

In what American analysts see as a move to cover the Soviet units during - Soviet officials seem resigned to this from Kabul southward in the early turn of events, one Western diplomas morning hours of April 11, apparently said. "What we're getting is a shrug," to beef up defenses of the so-callec he said. "Their only question is, "Do you "ring road," the main highway that think the mujahedeen will attack ou runs in a U-shaped loop from Kabu troops on the way out?" ".

down through Kandahar and up to the

In anticipation of their withdrawal Soviet border. Soviet officials have tolc which is scheduled to begin May 15 Western diplomats that this would be a Soviet units have been reported pulling main route of withdrawal. back from border positions, consolidat.

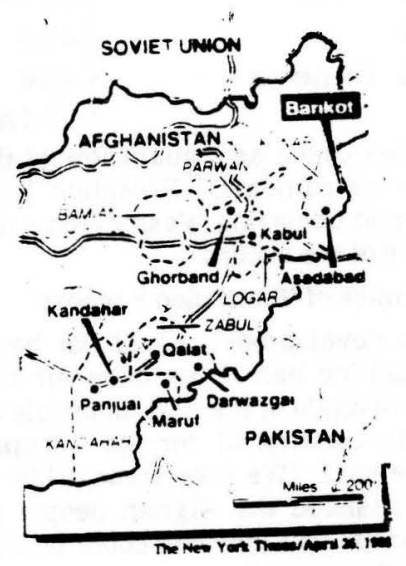

4/26 - ABC Nightly News In Kabul the 10th anniversary of the April Revolution was celebrated with speeches \& a parade featuring tanks \& rocket launchers. The applause was pre-recorcied.
4/27 - NYT - The highest ranking Soviet official attending the anniversary festivities was Vladimir P. Orlov, chmn. of the USSR's Supreme Soviet.

4/28 - NYT - A truck bomb explosion in Kabul killed $\overline{6 \&}$ injured 49 people yesterday. The truck reportedly had a Pakistani license plate, indicating that guerrillas were responsible.

- Tìe US Embassy sent home 4 of 1 ts 13 staft members after receiving reports that Iran was planning to attack the embassy in reprisal for US actions in the Persian Gulf.

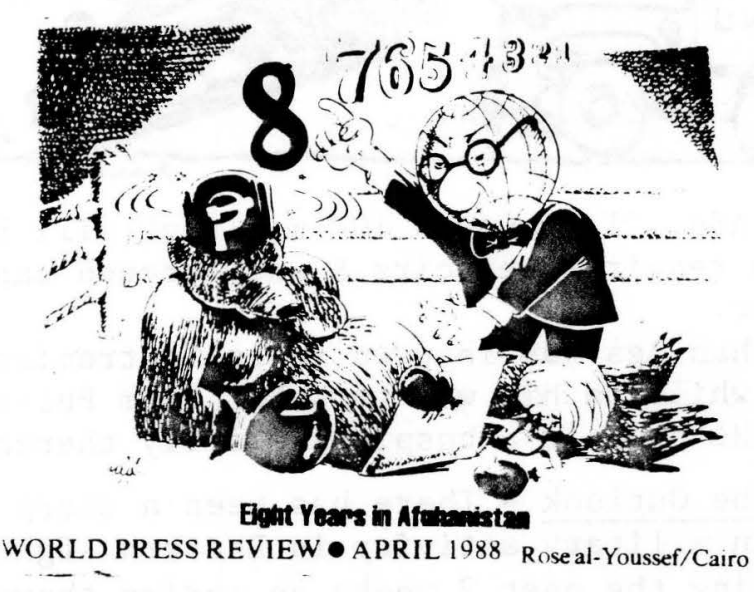




\section{Key Sections of Accords on Afghanistan}

spocial to the Now Yon timeen

UNITED NATIONS, April 14 - Following are key sections of the agreements on Afshanistan that were signed today in Geneva, as made available by the United Nations. The two bilateral agreements were signed by $A$ ghanistan and Paleistan; the agreement on interrelationships was signed by those two countries with the Soviet Union and the United States signing as witnesses, and the Declaration on International Guarantees was signed by the United States and the Soviet Union.

\section{Bllateral Agreement}

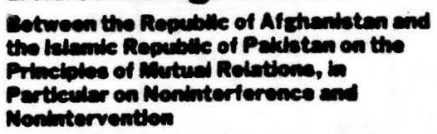

The Republic of Afghanistan and the is lamic Republic of Pakistan, hereinafter re ferred to as the High Contracting Parties,

Desiring to normalize relations and promote good neighborliness and cooperation as well as to strengthen international peace and security in the region.

Considering that full observance of the principle of noninterference and nenintervention in the internal and external affairs of states is of the greatest importance for the maintenance of intermational peace and security and for the fulfillment of the purposes and principles of the Charter of the United Nations,

Reaffirming the inalienable right of states freely to determine their own political, economic, cultural and social systems in accordance with the will of their peoples, without outside intervention. interference, subver sion, coercion or threat in any form what soever,

Mindful of the provisions of the Charter of the United Nations as well as the resolutions adopted by the United Nations on the principle of noninterference and nonintervention. in particular the Declaration on Prtaciples of in particular the Declaration on Primciples International Law Concerining Friendly Relations and Cooperation Among States in accordance with the Charter of the United Nations, of 24 October 1970. as well as the vention and Interference in the Internal As lairs of States, of 9 December 1981 .

Have agreed as follows:

\section{ARTICLEI}

Relations between the High Contracting Parties shall be conducted in strict compliance with the principle of noninterference and nonintervention by states in the affairs of ocher states.

\section{ARTICLE II}

For the purpose of implementing the prinerence and nonintervention each High Contracting Party undertakes to comply with the following obligations:

1 . To respect the sovereignty, political independence, territorial integrity, national unity, security and non-alignment of the other High Contracting Party, as well as the national identity and cultural heritage of its people;

2 To respect the sovereign and inalienable right of the other High Contracting Party freety to determine its own political, econom ic. cultural and social systems, to develop its international relations and to exercise permanent sovereignty over its natural re sources, in accordance with the will of its people, and without outside intervention, in people, and without outside intervention, in any form whatsoever:

3. To refrain from the threat or use of force in any form whatsoever so as not to violate the boundaries of each other, to disrupe the political social or economic order of the other High Contracting Party, to overthrow or change the political system of the other High cause tension between the High Contracting Parties:

4. To insure that its territory is not used in any manner which would violate the sover eignty, political independece, territorial in tegrity and national unity or disrupt the polilcal , economic and social stability of the other High Contracting Party

5. To refrain from armed intervention, subversion, military occupation or any other form of intervention and interference, over or covert, directed at the other High Contracting Party, or any act of military, politi- cal, or economic interference in the internal affairs of the other High Contracting Party, force;

6. To refrain from any action or attempt in whatever form or under whatever pretext to destabilize or 10 undermine the stability of the other High Contracting Party or any of its Institutions:

7. To refrain from the promotion, encour. agement or support, direct or indirect, of rebellious or secessionist activities againat the other High Contracting Party, under any pretext whatsoever, or from any other action which seeks to disrupt the unity or to undermine or subvert the political order of the ocher High Contracting Party;

8. To prevent within its territory the training, equipping, financing and recruitment of mercenaries from whatever origin for the purpose of hostile activities agains the other High Contracting Party, or the sending of such mercenaries into the territory of the other High Contracting Party and accordingly to deny facilities, including financing mercenaries;

9. To refrain from making any agreements or arrangements with other states designed to intervene or interfere in the internal and external affairs of the other High Contract. ing Party:

10. To abstain from any defamatory campaign, vilification or hostile propaganda for the purpose of intervening or interfering in the internal af

11. To prevent any assistance to or use of or plerance of terrorist groups, saboteurs or abversive agents against the other High Contracting Party;

12. To prevent within its territory the presence, harboring, in camps and bases or other wise, organizing, training. financing, equipping and arming of individuals and political. ethnic and any other gorups for the purpose of creating subversion, disorder or unrest in the territory of the other High Contracting Party and accordingly also to prevent the use Party and accortingly aiso to prevertation of arms, ammunition and equipment by such individuals and groups:

13. Not to resorr 10 or to allow any other action that could be considered as interference or intervention.

\section{ARTRCLE III}

The present agreement shall enter into force on 15 May 1988

\section{ARIICLE $N$}

Any steps that may be required in order to enable the High Contracting Parties to comply with the provisions of Article II of this agreement shall be completed by the date on which this agreement enters into force.

\section{Declaration On International Guarantees}

The Governments of the Union of Soviet Socialist Republics and of the United States of Amenca,

Expressing support that the Republic of Afghanistan and the Islamic Republic of Pakistan have concluded a negotiated political settlement designed to normalize relations and promote good neighborliness between the two countries as well as to strengthen incer

in the region:

Wishing in turn to contribute to the achievement of the objectives that the Re public of Afghanistan and the Islamic Republic of Pakistan have set themselves, and with a view to insuring respect for their sovereignty, independence, territorial integrity and yonalignment

Undertake to invariably refrain from any form of interference and intervention in the internal affairs of the Republic of Afghan stan and the Islamic Republic of Pakistan and to respect the commitments contained in the Bilateral Agreement Between the Republic of Afghanistan and the Islamic Republic of Pakistan on the Principles of Mutual Rela tions, in Particular on Noninterference and Nonintervention:

Urge all states to act likewise.

The present declaration shall enter into force on 15 May 1988

\section{Bllateral Asreement}

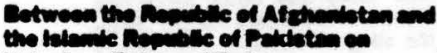

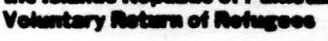

The Republic of Afghanistan and the it lamic Republic of Pakistan, hereinafter lerred to as the High Contractins Parties,

Desiring to normalize relations and pro

mote good neighborliness and cooperation as well as to strengthen ince

Convinced that voluntary and unimpeded repatriation conettutes the moat appropriate colution for the problem of Afghan retugees present in the Ialamic Republic of Pakietan and having ascertained that the arrange ments for the return of the Afthan retugees are satiafactory to them,

\section{AITCLI}

All Aighan refugees temporarily present in the territory of the Islamic Republic of Pakjstan shall be given the opportunity to return voluntarily to their homeland in accordance in the present agreement.

\section{ARTKCLE II}

The Government of the Republic of Atghanistan shail take all neceseary meacures to insure the following conditions for the homeland:

a. All refugees shall be allowed to return in freedom to their homeland:

b. All returnees shall enjoy the free choice of domicile and freedom of movement within the Republic of Afghanistan;

c. All returnees shall enjoy the right to work, to adequate living conditions and to share in the welfare of the state

d. All returnees shall enjoy the right to participate on an equal basis in the civic affairs of the Republic of Afghanistan. They shall be insured equal benefits from the solution of the land question on the basis of the $L$ and and Water Reform:

e. All returnees shall enjoy the same rights and privileges, including freedora of religion, and have the same obligations and responsibilities as any other citizens of the Re

The Government of the Republic of Afghanistan undertakes to implement these measures and $t 0$ provide, within its possibilities, all necessary assistance in the process

\section{ARTICLE III}

The Government of the Isiamic Republic of Pakistan shall facilitute the voluntary, or derly and peecetul repatriation of all Afghan refugees staying within its territory and undretakes to provide. within its possibilities, repatration.

\section{ARTICLI IV}

For the purpose of organizing, coordinating and supervising the operations which should effect the voluntary, orderly and peaceful repatriation of Afghan refugees. there shall be set up mixed commissions in accordance with the established internatjonal practice. For the performance of their unctions and members of the commissione and their staff shall be accorded the necessary facilities, and have access to the relevant areas within the territories of the High Contracting Parties.

\section{ARTICLE V}

With a view to the orderly movement of the returnees, the commissions shall determine frontier crossing points and establish neces. sary transit centers. They shall also establish all other modalities for the phased return of refugees, including registration and com munication to the counery of return of the names of refugees who express the wish to return.

\section{ARTICLE V}

At the request of the Governments conermed, the United Nations High Commis. sioner for Refugees will cooperate and provide assjstance in the process of voluntary repatriation of refugees in accordance with the present agreement. Special agreements 
raped to insure tull compliance with all the provitions of the instruments be coms. Thed fatth

7. Iv coneider alleged violations and to

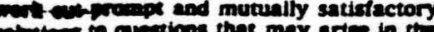
to quections that may arte in the ina

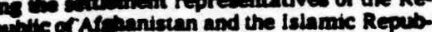
lic of Palitian halll meet whenever required. A repponited Nations shall lend his good of. of the Unitrd Nations shall lend his good of. bces is the parties and in that contexd he will partchele th them. He may submit to the partictipate them. He may submit to the uis and recommendations for promph, faithful and complete observance of the proviatons of the instruments.

in order to enable him to fulfil his tasks, the tepremative shall be assiated by such per. conder his authority as required. On his cintingtive or at the requeas of any of the parive the personnel shall investigate any parive, the personnel shall investigate any possible violations of any of the provisions of the inatruments and prepare a report thereon. For that purpose, the representative and his personal shall receive all the necessary cooperation from the parties, including al freedom of movement within their respective tion.

The modalities and logistical arrange ments for the work of the representative an the personnel under his authority as agreed upon with the parties are set out in the Memorandum of Understanding, which ts an nexed to and is part of this agreement.

\section{Annex}

\section{Meverendon of Underetanome}

\section{BASHC RECUREIMENTS}

a. The parties will provide full support and cooperation to the representative of the Secretary General and

ined to assist him;

b. The representative of the Secrectary General and his personnel will be accorded every fecility as well as prompt and effective assistance, including freedom of movemen and communications, accommodation, transportation and other facilities that may be

c. Afghanistan and Pakistan will be responsible for the safety of the representauve of the Secretary General and his personnel while operating in their respective countries d. In performing their functions, the repre sentative of the Secretary General and his staff will act with complete impartiality. Th representative of the Secretary General and his perzonnel must not interfere in the internal affairs of Afghanistan and Pakistan and in this conters, cannot be used to secure ad. vantages for any of the Parties concerned.

\section{MODUS OPERANDI \\ AND THE PERSONNEL} ORGANization

The Secretary General will appoint a sen ior military officer as deputy to the repre sentative, who will be stationed in the area as head of two small headquarters units, one in Kabul and the other in Islamabad, each comprising five military officers, drawn from existing United nations operations, and a small civilian auxiliary staff.

The two headquarters units will be organ ized into tro Inspection Teams to ascertain on the ground any violation of the instruments comprising the settlement. Wheneve considered necessary by the representative of the Secretary General or his deputy, up to 40 additional military officers (some 10 additional Inspection Teams) will be redeptoyed from existing operations within the shoriest possible time (normally a round 48 hours).

The nationalities of all the Officers will be determined in consultation with the parties.

\section{PROCEDURE}

a. Inspections conducted at the request of the Partie:

A complaint regarding a violation of the instruments of the settiement lodged by any of the parties should be submitted in writing in the English language to the respective headquarters units and should indicate al relevant information and details. ii. Upen receipt of a complaint the depury to the representative of the Secretary Gen aral will immediately iaform the other perty of the complaint and undertake on inveatation by making on-site inspections, gathering testimony and using any ocher procedure which he may deem neceasary for the inves tigation of the allesed violation. such inspec. ilo will be contucted usth headquarters staff as referred to above, unies the deputy staif as referred to above, unieas the deputy representative of the Secretery-General considers that additional teams are needed in that case, the parties will, under the princtpl of freedom of movemem, allow immediate speetive territicories

iil. Reports on investigations will be pre pared in English and submitted by the deputy representative of the secretary Generat the two governmencs, on a confidential be (A third copy of the report will be simenis neousiy transmitted, on a confidencial bests. to United Nations Headquarters in New Yort, exchusively for the information of the Secretary General and his represencative.) In accordance with Paragraph 7, a report on In accordance with Paragraph 7, a report on meeting of the farties not later than 48 hours after it has been submitted. The deputy representative of the Secretary General will, in the absence of the representative. lend his good offices to the parites and in that context he will assist in the organization of the meet ings and participate in them. In the context of those meetings the deputy representative of the Secretary General may submit to the parties for their consideration and approva suggestions and recommendations for the prompt, faithful and complete observance of the provision of the instruments. (Such sugsestions and recommendations will be, as a mattier of course, consulted with, and cleared by, the representative of the secrecleary General.)

b. Inspections conducted on the intiative of the Deputy Representative of the Secretary. General

In addition to inspections requested by the parties, the deputy representative of the Secretary General may carry out on his own initiative and in consultation with the repreentative inspections he deems appropriate for the purpose of the implementation of Paragraph 7. If it is considered that the conclusions reached in an inspection justufy a report to the parties, the same procedure used in submitting reports in connection with, inspections carned out at the request of the Parties will be followed.

\section{DURATION}

The Deputy to the Representative of the Secretary General and the other personnel will be established in the area not later than 20 days before the entry into force of the instruments. The arrangements will cease to exist two months after the completion of all ime frames envisaged for the implementa. tion of the instruments.

\section{THE NEW YORK TIMES.}

\section{FRIDAY, APRIL IS}

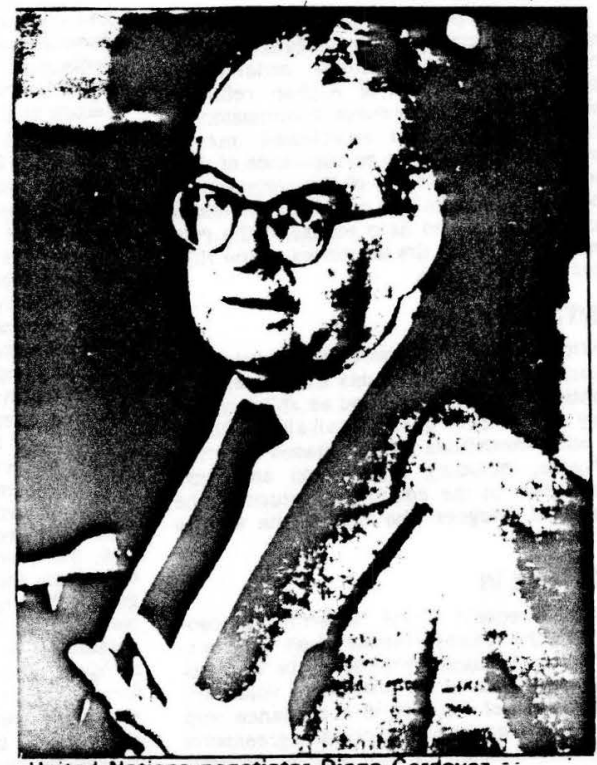

United Nations negotiator Diego Cordovez
Plans are afoot to create an Int'l Institute for Afghan Studies to facilitate scholarly research on Afghanistan. Among other things the Institute would prepare an inventory of Afghan archaeological \& historical sites, archives \& libraries so that war damages can be recorded. It would also encourage studies on the effects of the war on Afghan society. The FORUM will have more information on this project in future issues.

From an article by Michael Reisman in The Hartford Courant 4/24:

The agreements aren't bad for everyone. Gorbachev has turned certain defeat into a fair and economical shot at victory. President Reagan looks good and can go to Moscow in May like a winner. The United Nations looks like it works; it brokered the deal and can claim that it performs an important peace-making role. Najib has a better chance of staying in power than at any time since be seized it.

Perhaps this is what peace bas come to mean in the waning years of the 20th century. Considering that Henry A. Kissinger got his Nobel Prize for bringing peace to Vietnam, and Egyptian President Anwar Sadat and Israeli Prime Minister Menachem Begin shared one for bring. ing peace to the Middle East, there may yet be a few laureates here.

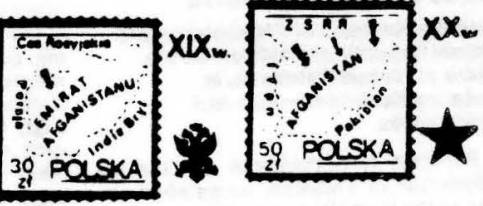

Po: isin

postage

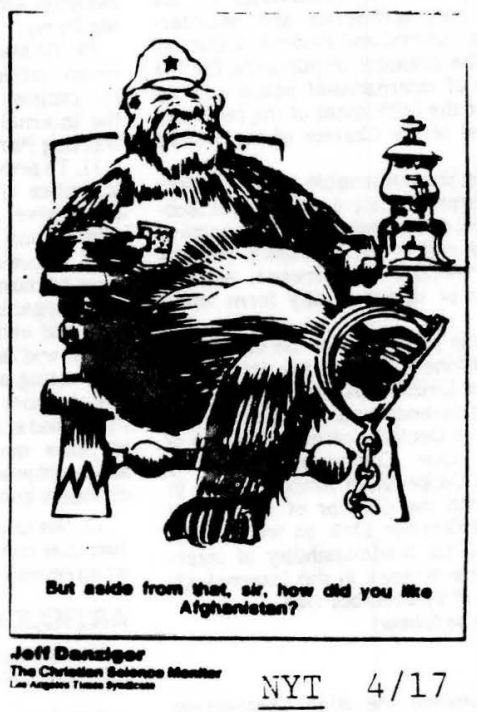

\section{Afghan Talks Are Strain to All}

\section{BY PAUL LEWIS}

GENEVA, April 4 - As the deadocked Afghan peace talks enter their signs of strain and are expressing signs of strain and are

A peace treaty is all but ready for signature. The sticking point is Wash ington's insistence that the Sovie Union and the United States both suspend military aid to the two sides when the treaty comes into effect and a Soviet withdrawal begins. Moscow re jects the demand.

Deputy Assistant Secretary of State Robert A. Peck, a usually cheerful fisure who watches the negotiations for able to conceal his frustration with the continuing deadlock today.

"We've been working at it for a lons time and we may be running out of ideas," he said.

Even Zain Noorani, the normally optimistic Pakistani negotiator, who rep resents the Afghan guerrillas battling Kabul, conceded that "this can't go on forever."

\section{A Set Choreography}

By now, the ritual for the negotiations is established. Usually, the Pakistani delegation arrives first and climbs a marble stairway to an ornately decorated conference room in the building that was once the head
,1 a

Mr. Noorani, a tough-looking, heavily built man with tinted glasses, likes to banter with journalists as he passes through the entrance hall. As negotiations have proceeded. his broken righ wrist is slowly emerging from a cocoon of bandages, prompting the United $\mathrm{Na}$ tons mediator. Under Secretary General Diego Cordovez, to say excitedly, "Look, he's getting ready to sign peace treaty.

A tew minutes after the Pakistan delegation has gone upstairs, the Af ghan Government team arrives, led by oreign Minister Abdul Wahil, a slighi, neauly dressed figure who speaks little English but never fails to flash a smile. Since the two sides refuse to meet. the Afghans go to a separate conference room with a magnificent carpet donated by the late Shah of Iran, and Mr. Cordovez shuttles between the two delegations trying to nudge them closer together.

In the afternoon, the representatives of the superpowers, which arm the pro tagonists in the civil war, come to taik with $\mathrm{Mr}$. Cordovez. Like the Pakistanis and the Alghans in the morning $\mathrm{Mr}$. Peck and the Soviet special representa. arrive at difter. ive, Nikolai Kozyrev, arriv

Mr. Cordovez now seems to be strug. gling to keep the negotiators here marking time while Washington and Moscow try to resolve their dispute. 


\section{The Afghans win another round in the Great Game}

TIPLNG'S Great Game was moved to - Geneva for the day, where it was re duced to a tennis-match with balls of paper. The foreign ministers of the United States The foreign ministers of the United Stares stan and Pakistan, sat down on April 14ch to confront 39 pages' worth of documents in four languages. The Russians and Americans promised to guarantee the Afghan-Pakistani peace treaty that had been put to gether by Mr Diego Cordover, the United Nations mediator, after six years of negotiations. All of the Soviet Union's 115,000 or so troops are to be withdrawn from Afghanistan by next February 15ch.

The Russians have thereby formally re nounced ambitions towards their small neighbour that date back to an invasion plan they drew up in 1791, when Russia's opponent was Britain

The signing ended a long period of ma noeuvring that seemed about to end in tail ure. Early this month even Mr Cordovez, a world-class optimist, admitred that time was running out. The deal was being blocked by a dispure over whether the Russians could go on arming their Afghans after the Americans had cur off supplies to theirs. The exas perated Russians threatened to start pulling out of Afghanistan withour an agreement. wich could have made things even messier wan the agreed deal is likeiv to be.

Mr Mikhail Gorbachev eventually saved the day by accepting a version of the "symmetry" in military aid demanded by the Americans. His foreign minister, Mr Edward Shevardnadze, flew to Kabul to break the news to the hapless Afghan president. Mr Najibullah, who then went to the Sovier iry of Tashkent on April 6th to have his rm ryisred by $\mathrm{Mr}$ Gorbachev himseif.

The agreement signed in Geneva does nor include the vital understanding on "symmerry". That remains a separate deal berween the superpowers, because Russia refused to accept a public display of what it called interference in its relations with a sov. ereign state. It appears that both America and Russia may initially suspend arms sup. plies to their friends during the nine-month withdrawal period, but either is free to resume them if it reckons the other has. The proviso seems fated to be invoked, though how America's right to send more supplies to the guerrillas is to be squared with Pakistan's promise not to heip them remains one of those mysteries of international diplo macy. Mutual suspicion may be heid in check, though noc much, by the presence of 60 or so UN Observers.

It is a fairlv safe prediction that the peace treary will not at first produce much pesce. It is hard to imagine the Afghans setding the future government of their country without some more violence. The guerrillas. vutraged that the agreement has been concluded over their heads, sav thev will ignore it. Thev have sworn to fight the communist government in Kabul uncil it collapses. Then, or even before then, they may turn on each orher.

That is not a universal upinion, to be sure. Some blithe spirits think that the guerrillas will become statesmen once they see that the Russians are going. The Pakistani government even professes to think that guerrillas and communists can come to gether, at least for a time, in a coalition government. It fears that otherwise the $31 / 2 \mathrm{~m}$ or so Afghan refugees on Pakistani soil will nor go home. and more mav come. To please $\mathrm{Pa}$ kistan, Mr Cordovez has agreed to trv for such a coalition. He is unlikelv to succeed.

Iran, which sheiters neariv $21 / 2 \mathrm{~m}$ Afghans, is harder-headed. A staunch supporter of the Afghan resistance, at least in words, it used to oppose the Geneva talks because thev included the Kabul govern ment. It now resists the imposition ot a deal specifving what the future government of Atghanistan should be, saving the Atghan should have the right of self-determination.

The Iranians doubriess hope to influence the "Islamic government" that the guerrillas racher vaguely say they want to establish. But since most Afghans are Sunni Muslims. hey may nor look to Shia Iran for guidance.

Whatever outsiders do, a final trial of strength between the communists and the resistance seems almost inevitable. So does a resistance victory. Whether this takes week or monehs (or, Allah forbid, years) depends on how many communists flee to the Soviet Union (some evacuation cards are already being issued) and 1 how far either side can unite against its enemy. The Afghan communist party has been angrily and some times bloodily divided between its Khalq and Parcham wings for two decades. $A$ bid to assassinate a Politburo member last month, and two bombs found in the ince ror ministry, are put down to intra-party feuding

But the prize for splintering must go to the resistance (see box). The Pakistan-based guerrilla alliance cannot agree even on a permanent chief. One of the seven leaders recently accused another of trying to murder him; such charges are nor new. Under Pakistani pressure the guerrillas pur forward a vague proposal for a coalition government in Kabul but picked a nonentity to head it. thereby showing they were nor serious. The alliance's chairman for the current three monchs, Mr Gulbuddin Heckmatyar, is inordinately ambitious.

Afghanistan's bese chance of peace may ie with the men who are actually doing the fighting. Their hard-learned co-operation in the field purs to shame the haggling of the political bosses who spend their time in $\mathrm{Pa}$ kistan. The tighting men would not tolerate communss rule (some began fighting it even before the Russians came in to heip the local communists), but they may be less ready to die in a struggle over what replaces it. One commander, Mr Abdul Haq, has said he would racher study or go back to his farm. If that sounds too good to be true, remember that this war has killed more than Im Afghans out of $15 \mathrm{~m}$, driven neariv $6 \mathrm{~m}$ into foreign refugee camps and cost another $3 \mathrm{~m}$ heir homes inside Afghanistan.

The lovality of most of the fighting men, and of most of the refugees, to any of the Pakisran-based politicians has been partily a marter of tactics. A poll in the Pakistan camps last year showed that less than $1 \%$ of the refugees wanted any of the faction leaders as Afghanistan's ruler. Some of the com manders in the field, on the other hand, have grown into popular heroes. These men have the support of their own tribes. None, it seems likely, could control the whole country; but between them they can ensure that any government in Kabul will be a weak one. That is in Afghan tradition. Such an outcome would be untidy, but it is what the Geneva signatories should be hoping for. Kipling could have told them so.

THE ECONOMIST APAH 161960

\section{As Russia retreats}

\HEN great powers suffer grear defears, the earth shakes. It does nor always move. The documents signed in Geneva this week formalised a fact that had long been ap parent, not least to Mikhail Gorbachev: the

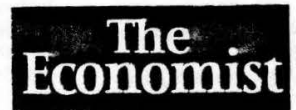

Sovier Union has lost in Afghanistan. : .

For the Afghans themseives, unhappily, the suffering is far rom over. . .

Nubody gives much of a chance to the talks that are to start un a Kabul-guerrilla coalition. America and Russia are racing to put as many weapons as possible into their friends' hands before the deal's contorted and conditional restraints on arms deliveries take effect. Who eventually runs Afghanistan is still to be decided by war, or bv negotiations after the various sides have weighed up their chances in such a war.
The Afghan jigsaw

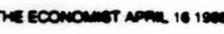

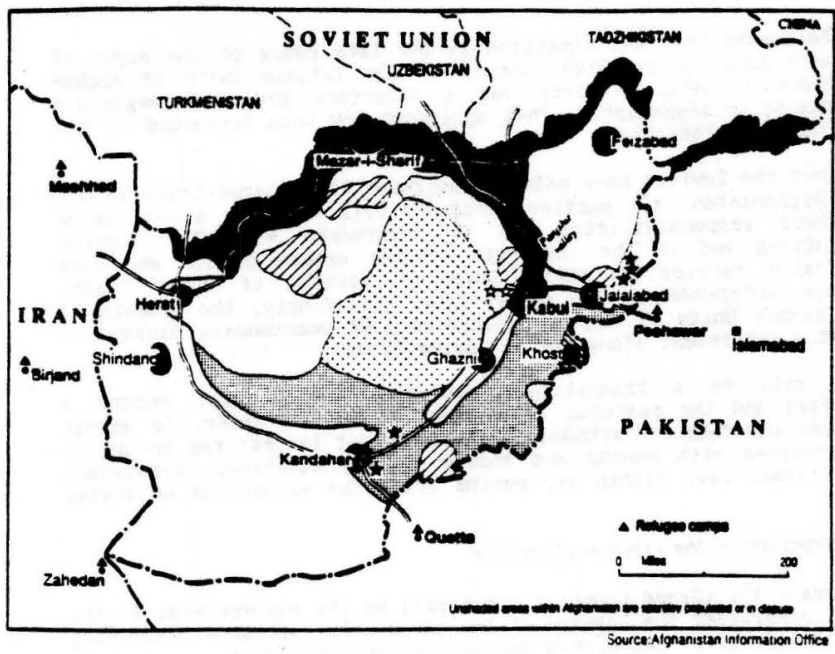

Fundamentaliets

Jamiat-i-Isiami, led by Mr Barhannudin Rabbani, a reasonable man who was a professor of Isiamic .

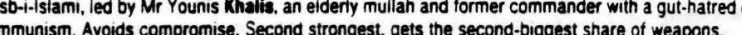

Tesb-i-lslami (rival faction), led by Mr Gulbuddin Hectematyar. Anti-western and opportunistic. Third-

Ittehad-i-tslami, led by Mr Rasul Sayat, a Wahhabi Mustim. Has bought guernila support with huge aditienaliats

Harakat-i-inqilab-i-islami, led by Mr Nabi Mohammedi, is a party of village mullans. III-organised.

National Islamic Front of Atghanistan, led by Pir Sayyed Ahmed Gailani. a westernised Pathan with plenty of religious followers because he is a hereditary Sufi saint.

National Front for the Rescue of Aighanistan. led by Sigbatulan Mojadedi. a westernised professor and monarchist from a leading religious family. Gets least aid, and achieves little with it.

ain guerrilla commanders

Abdul Haq attacks Kabul and is noted for his assauits on power lines. Affiliated to Hesb (Khalis).

smail Kham, operates with deadty efficiency around Herat, close to Iran. Affiliated to Jamiat.

Other anti-communiste

Shia Musiim groups operate, but do little. (All members of the resistance alliance are Sunnı Mustim.)

Other independent groups, of mixed control

The Russians, and the People's Democratic party of Afghanistan. The Afghan party split a few years atter it was formed in 1965. The city-based Parcham faction is Darl-speaking (a form of Persian), the Khalq faction rural and Pashtu-speaking. They hate each other. President Majibullah is the leading Parchamite, the interior minister Mr Mohammed Getseces the top Khaiqi.

It has nonetheless been right for America to agree to this deal. One reason is that almost all Afghans want the Russians out of their country: they have voted for this with their APRIL 16 teet and their lives. The deal shoves the Russians firmily to the door. The Afghans mav then sertle their own differences violentlv, but

at least it is Afghans who will settle them. .. The Russia that has lost in Afghanistan is in much worse general shape than the America that lost in Viernam. The United States was then soul searching over Watergate, and its Johnson-fostered great inflation was in train. But it still had the world's stablest democracy and richest economy. The Soviet Union that is staggering out of Afghanistan is, on $\mathrm{Mr}$ Gorbachev's sombre admission, a place in need of revolution. In a few decades its economv will be in a wheeichair pushed by the Chinese uniess brave things are done to save it.

Russia is in a bad way. But a bad position can be rescued by good statecraft, and Mr Gorbachev's statecraft is exceptional. :-..

Too manv people want to be lieve that Mr Gorbachev is not oniv a man vou can do bustness with but one who, when vou do it, does not drive a nard bargain. His whole programme-the economic reforms, the diplomatic boldness - is intended to make his countrv a more formidable adversarv for the West, nor a partner with it. Rus sia has been beaten by the Afghan guerrillas. Applause for that. But it is still a great power, of great ambition. 


\section{FOAMULA FOR A TRANSITIONRL GOUERNMENT IN AFGUANISTAN}

me following text vas finalised in the late how of the night of Fobruary 22nd by the Hich Council of the Islanic linity of Afthen Wwjahideen (IUAI). It sets out a structure for a trussitional governaent in Afthanst

How that the Sorlets have ade a comitent to vithdraw their forces fron Afghanistan, all parties concerned vill act nth a full sense of their responsibilities and in accordance vith the suprese aspirations and in the interests of the Afghan people wo have heroically carried on their Jehad in defense of their faith, freedom. independence. and sovereignty. Accordingly, the leaders of accept a settleaent aland the following lines:

There vil be a transitional governaent wich vill ensure a ceasefire and the peaceful transition to lav and order, to pernit the safe and conplete $n$ thdraval of the Soviet forces: the return of the refugees inth honour and ensure general elections, consistent with Islanic law, vithin siz nonths after the vithdraval of Soviet forces.

\section{The structure of the stote will inciude:}

A Shoora-e-Ali (Grand Council) mich vill be the suprese body of the state, comprsing the leaders of the seven party alliance. Mis body vili provide juint leadership during the interia period.

A bradd-based transitional govemaent representing all sections of the Afghan nation. This government is proposed to replace the present regine in Kabul before the signing of the Geneva accords vich it vill $31 \mathrm{gn}$ w.der the suspices of the United Mations organization.

The governaent vill consist of a cabinet of 28 nunisters under a P.zees-1-Huknat (head of govermment) tho w11 also be the Raees-1[izulat head of statel. The cabinet will consist of fourteen Mujasideen, zeven refugees and seven usilins presently living in Kabul.

There nll be a Mushavrati Shoora (Consultative Counc1l) comprising 75 meabers dran two frm each province (56) and one third $(19)$ from the Ulean, intellectuals and technocrats. This nil fram interis lavs to $\mathrm{mn}$ the country till the fornation of the nev constitution by an elected shoor (Constituent Asseably). Provincial councils vill be set up by mutual consultations to run the demistrations in vill be set up by mutual consultations

A fully autonosous comission vill be set up to drav up procectures and rules for holding elections to the shoor (Constituent Asseably), imediately after the vithdraval of the Soriet forces. The name of the future Afghanistan vill be "Doulat-i-Islani Afghanistan" (Islanic State of Afghanistan merein the duran and and elected head.

IDAM has also decided to set up a Reconstruction Casaission imediately and call upon all qualified Afthans to apply for appountwents to this body wich vill start functioning at the appointaients to this

The transitional goverment vill sign the Geneva accords and indertake full responsibility for their iaplesentation including the safe return of the Soriet forces when the accords becone acceptable to the transitional goverment. The transitional goverment vill pursue an independent and non-aligned foreion policy and vill have friendly relations wth all countries, particularly vith its neighbors, provided that there is no interference in its internal affarrs. For the purpose of reconstruction the IUN requests all the
countries of the vorld, and in particular the Soviet onion, to participate generously in reconstruction of the infrastructure and

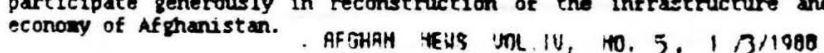

\section{NO SMOKING IN PANUSHIR}

The council of the the comanders of Panjshir was convened in the uddile of Decenber. In this neeting ailitary and non-nilitary natters facing the people vere discussed and docisions vere ando.

One of the itens on the agenda vas the baming of cigarettes and use of sruiff in the valley. In the past the thishideen and the people vere encouraged to quit sooking and using srusf. The new decision akes the use of these itens against the law. According to this law, not only saoking clgarete and using smiff, but buring and selling not only smoking clgarette and using smuff, but burying and sell ix

mis decision was taken in accordance vith the tenants of Isla wich forbid using things that ake people unhoeltiny. Economic considerations also had an important role in the decision to bet snoking.

In other bases controlled by the Superrisory Council of the Horth, a soking cigarettes and using snuff.

The decision of banning snoking is bad nevs for clgarette producing comances mut very good news fnt hat ion hach is fighting for its freedon and needs to quit all bad habits hich do not sulte its charactor.
GULBUDDIN'S CAUSE :

\section{BY HENRY KAMM}

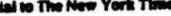

PESHAWAR, Pakistan, April 19 - In the crucial period that began just before the conclusion of the Geneva agreement on Afghanistan last week and will span the expected beginning of the Soviet troop withdrawal May 15, the political leadership of the guerrilla movement lies in the hands of the man considered the most redoubtable and ambitious of the leaders of the sevenparty alliance based here.

In a wide-ranging interview last weekend, the alliance chairman, Gulbuddin Hekmatyar, disclosed some of his views and gave an idea of the Afghanistan he would like to shape if the 'Guerrillas succeed in dislodging the Soviet troops will leave behind.

Mr. Hekmatyar is a 40-year-old Is'Iamic militant who uses the academic title "engineer," although he completed only two years of study at Kabul pleted only two years of stury work fullime to create a sovernment bas this interpretation of the Koran and Islamic law.

His party, the Islamie Party, is re garded by members of other guerrilla factions as the most tightly organized and disciplined.

Moderates regret that the rotation policy, which alternates the alliance leadership every three months, has made Mr. Hekmatyar chairman at a time when he can use the position to advance his ambition to lead a non-Communist Kabui.
munce his ambict

Is Democracy in the Future?

Asked about the post-Communist government that the alliance envisaged, Mr. Hekmatyar said it would be based on elections and be free, independent, nonaligned and Islamic. He said it would be a "consultative system with a strong center" but did not de scribe it as democratic.

Asked whether women would receive the right to vote, he avoided a reply. Challenged to answer, he declined to comment. "Some brothers have reservations in this regard," he said, referring to other alliance leaders but not stating his own view, "and we want to avoid controversial issues."

Women have had the vote in Afghanistan since before the monarchy was deposed in a coup in 1973 and continue to take part in elections under the Communist Government

Mr. Hekmatyar also refused to reply to a question on whether an alliance government would recognize Moscow's sovereignty over Soviet Central Asia. The more militant parties, like Mr. tion" of the largely Moslem regions of the Soviet Union an Islamic duty. Some guerrillas are reported to have staged guerrillas are reported to have staged

raids across the border, which wer

In response to questions on the curIn response to questions on the cur-
rent situation, $\mathrm{Mr}$. Hekmatyar, looking rent situation, Mr. Hekmatyar, looking Impassive but occasionally toying with rather than a speedy return of the refugees in Pakistan after the signing in Geneva, he

Pakistan.

"As long as there is war, the refugees will not go home, but more will come here," he said.

Mr. Hekmatyar reiterated the guerrillas' determination to fight until not only the Soviet forces but aiso the Communist Government of President Naji-
bullah are ousted. "No agreement can bullah are ousted. "No agreement can leader said of the President. "He will be finished even before the Sovi

The guerrilla leader said the guerrillas had begun to put into action a postGeneva strategy that foresaw steppedup attacks on remaining Soviet bases while the troops withdrew. He sald the ment under which safe passage would be granted.

Since Moscow refused to negotiate with the guerrillas, Mr. Hekmatyar continued, the guerrillas "are entitled to attack them until the last is gone."

The new strategy also includes, ac cording to Mr. Hekmatyar, a decision to concentrate attacks only on major
targets, particularly Kabul, the capital.

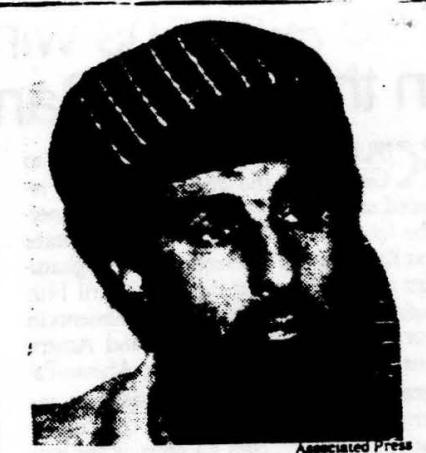

Gulbuddin Helamatyar, leader of an Afghan guerrill party, who denies that he is anti-American.

Feared by Outer Rebels

Most diplomats regard Mr. hekmatyar as the most competent and the most feared of the guerrilla leaders. But they said that he was not leared sc much by the Communists as by his allies and not regarded as the most asgressive rebel chiel. They believe that his commanders, although heavily armed. preferred to save their men and weapons to establish Hizbi Islaming the field to the Afghan factions.,

Although the Hekmatyar wing is not known to have distinguished itself in many actions against Soviet or pro Soviet Afghan forces, their leader's Is lamic zeal has motivated his troops tc mount occasional raids into Soviet Cen tral Asia. He is said to believe that the largely Moslem border republics of the Soviet Union are npe for Isiamic revolution.

The raids have consistently been fol lowed by devastating reprisals. in which entire Afghan villages have been leveled, according to diplomats.

THese envoys and Afghan moderates, who always speak anonymously and express fear for their lives if they ure identified. accuse Mr. Hekmatyar's units also of raiding caravans taking arms and supplies to forces of other parties. This has included a horse cara. van carrying medicine on behalf of the French relief organization Doctors Without Borders.

From a NYT article by $H . ~ K a m m$ on 3/19. Motee axsoo . 16

and a drive to take a major city. He did not specify which one, but diplomats in Islamabad speculate that an attack on Kandahar, the largest city of the south. may be part of the strategy

Criticism of U.S. and Pakistan

In reply to questions, Mr. Hekmatyar restated his long-standing criticisms of the United States and Pakistan over their readiness to reach the Geneva accord and serve as guaran

he did so in muted terms. tion that the agreement was the result of a Soviet-American "conspiracy" or his implied threat of disturbances among the three million Afghan refugees in Pakistan in reaction to the accord.

But to a large part of the Pakistani public that is hoping for a speedy departure of the refugees, the guerrilla leadership's public stand that the Afhans should remain until peace and an Islamic government have been re stored is a disappointment.

Unofficial Afghan sources expressed a belief that once the Soviet withdrawal was completed, many Afghans would defy their political leaders' stand and return. There is a growing belief among educated Alghans that the alliance leaders lear a decline in their powers once the Soviet Army has departed and settlement of the conflict is plained in part the leaders' insistence plained in part the leaders' insit the refugees wait and see.
that

NYT $4 / 20$ 


\section{The traditional}

leaders are at

odds with the

Islamic

fundamentalists.

\section{$\cdots$}

The seven Pakistan-based leaders are united in their opposition to any hanistan. But members of the traditonalist and fundamentalist grouping also say the other grouping is not repand bust be prevented from doutinating

"We are the backbone ul this resist"We" asserted Gulbugdin Hekmat yar, head of the Islamic Party, the trongest group among the fundamen alists He said the three so-called raditional parties "are part of an old feudal system" that must yieid.

'Wishes of the People'

The traditional parties disoute Mr. Hekmatyar's claims, sayms that unce he war is over. Afghans will again loo or leadership to tribal and ers and the Mosiem clergymen allied with them.

What these four parties want is not in accordance with the wishes of the people of Afghanistan," said Zabihul ah Mojadedi, a leader of the Afghan tan National Liberation Front, a tradiivinalist group. "The people never even heard of them before the war

Mr. Mojadedi is the son of Sibgatullah Mojadedi, leader of the Liberation Front and an outspoken advocate of the roturn of the exiled Afghan King. which leturn of the exiled Afghan King Foreign Aid Faulted

Like many otner traditionalists. Zubihullah Mojadedi said the anti-Government movement was distorted ernment movement was distorted and Pakistan channeled most foreign and Pakistan channeled most foreign covert assistance - estimated at more than 1 illion from all sources las year - to Mr. Hekmatyar or other fundamentalists. Military analysts say the

fundamentalists are stronger
tarily than the traditionalists.

Relief workers and others connected to the insurgents say there has been an increase in warfare among the different groups inside Afghanistan:

They also charge that Mr. Hekmatyar's group has attacked other rebe groups and is determined to bring isous an

"The Americans took on Gulbuddin because he was the most militant, he ad the best organization and it suited heir purpose," sald a Pakistanı invoived in the aid. "Now they realize he has to be slowed down."

Mr. Hekmatyar, in an interview, acnowleaged inere had betu clashes but denied that his group had ever at lacked any nther group. There is no internal likniıng un ine levei or the vardes." he said. "If theite is all uodu case. it is on the individuat levei.

\section{Legacy of Feudalism}

The Iraditionalists are not necesarily secular, and in some cases they have strung ties to Mosiem clergy, Islamic scholars and spiritual leaders. But much of cheir duthority jerives from the power of hundreds of tribes, clans and other autonomous subgroups in Aighanistan whose leadership has been largely hereditary. Historians say that all kings and civil authorities in Afghanistan in modern times have ruled by accommodating these fiefruled by accommodating these

doms rather than subduing them.

For example, Sayed Ahmed Gailani. leader of the National Islamic Front for Afghanistan, is a traditionalist but is also respected as a hereditary saint in the Sufi Moslem sect. He owned a Peugeot dealership in Kabul before the Marxists took over in 1978 .

The so-called fundamentalists were mostly trained in secular institutions, such as Kabul University, where they formed a vision of Islam as an allencompassing guide for life and politics.
Alt-Encompassiag Islam In the 1960's, many of the current undamentalist guerrilla leaders and the current leaders of the Kabul reUniversity, where they held competung demonstrations and forged incompe ible visions of Afghan society.

The fundamentalists started their in The fundamentalists started their insurgency against Kabui in the mid-
1970 's, lony before the coup of 1978 and 1970's, long before the coup

But the fundamentalists' battlefiejd

credentials might not translate into credentials might not translate into Afghan Rebels' Discord
Widens as Pullout Nears

\section{Dy HENIT KANTI}

March 8 -

PESHAWAR, Pakistan, March $8-$ Moderate officials of parties belonging
to th Afchan insurgents' political attiance are fearful of expressing their liance are fearful of expressing their viems fulfy and frankly because of the cates of fundamentalist Isiam, who cates of fundamentalist lsiam, who conilition

A Weutem official said the moder. ales coprated undter "a kind of mada memalis retom of fear."

All seven alliance parties describe themselve as Meciems who are sup porttes a baly war for Islam, to rid $A$ ghantian of the Soviet troop and the

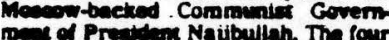
partis cenerally described as funds. menclute are more powerful the to thre sealled moderail pa

at the of the moven

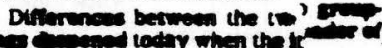

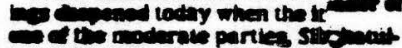

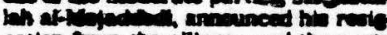

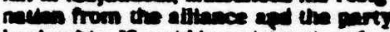

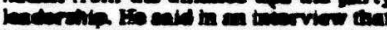
in rected us ur the of the four fund nolie parties te annource on ia ati cumment to bo hed by

Pakisian Urges Interim Rule

An aide said the Pakistani Interserv. ices Intelligence, the agency that manages Pakistan's relations with the insurgents and distributes the arms supplied by ouner countries, notably the United States, had presen Mr. Mojaddedi to agree to the Government. In the indirect Geneva negotiations between Pakiatan and the Alghan regime, Pakistan insists that an interim Government be named 10 guarantee peace while the Soviet troops withdraw.

Mr. Mojaddedi said Pakistan fa vored the fundamentalist parties, particularly in the distribution of arms Asked whether his stand would deprive the guerrillas that support him of arms, he replied: "It's up to Pakistan. They are responsible to God."

The moderates, none of whom would favor secular government in the West. em sense, say they believe that the fundamentalists' goais are to establish an Islamic regime more radical than any in pre-Communist Afghanistan. They say that the aim of the radical "Islamists" is not only to undo the attempt to impoese Communism, which led to civil war and the Soviet move inco $A f$ ghanistan in December 1979, but also to reverse the social modernization that preceded the overthrow of King Mo hammad Zahir Shah in 1973.

\section{Zealury is Feared}

The moderates say the fundamentalists intend to install a regime of religious zeatotry, which would be marked by the toral isolation of women from education and public life, the strict ap plication of Islamic law and the ham-

Kushkaki, who directs a cultural group the Afghan rebels,

The Afghan peopie's approach to slam is different from the one put forushikaki said.

"But we will never revert to the few al structure, because these young resistance leaders have come to the ore," Mr. Kushkaki added. "These are ople in their 20's and 30's who will Excerpts from an article by steven pering of modern economic activity by subjecting it to the restrictions on fiance imposed by the Koran.

They fear that such an Afghanistan would turn away from the Western world that has supported the insurgents and on which they count for the rehabilitation of their country.

But while the fundamentalists express their views fully - and appear to be enjoying the support of the Governmenl of Pakistan - the moderates speak their minds freely only when assured of anonymity.

In the villas and compounds occupied by the leaders of the alliance parties where visitors must shake hands in Af. ghan style with many an armed guard ant inquisitive aide before being adexpo- vigually idencical hold and publichy bexpesied viewatedy been greathy helyoures according to Afghan and Weaternet according to Afghan and Westermers close to the Prot. Syed Majroon at his home and of fice in Peahnjow at his home and ofheaded the Alghan Information Center. headed the Alghan Information Center,
which had won a reputation for objec. which had won
tive reportin:

The United States Government, as well as private Wentern sources, in nanced the center's wort.

In public, the unsolved assassination is attributed to agents of the Kabul regima. Prtvacely, however, some moderate Afehans and Weiterners say they believe surongly that the iormer dean of literature at Kabul University had becte to ma the price for lons givin cliosise to the mose militant fus giving callows

Hiv bat poutused wrvey reported that aboue $\pi$ preane of Afghan refu. goce faved a salution under the mgderate lesche of the tormer king.

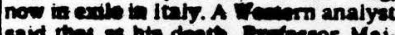
said the a his death, Fritessor Majrook had boes prepart o publiah a repont soyle that the militanthy his around in ?

\section{This Kins and His ketse}

Asked whether he shared the suspi cion against the fundamentalists, $\mathrm{Mr}$. Mojaddedi replied: "Perhaps. Many people are assassinated by them.

To the fundamentalists, as well as their Pakistani backers, mention of Zahir Shah's return in any role is anathema. To the Afghans, the King's 40-year reign was marked by a yielding of Islam to modernism; to Pakistan, he recalls years of bilateral tension. leaning toward India and the only vote east in the United Nations in 1947 against the admission of Pakistan.

- No Afghan leader here supports the King openly. "Professor Majrooh was the only one who transmjtted the true message of Afghanistan to the world,' one moderate said. "For that he was murdered."

In the moderate view, the fundamentalist parties are striving to submerge

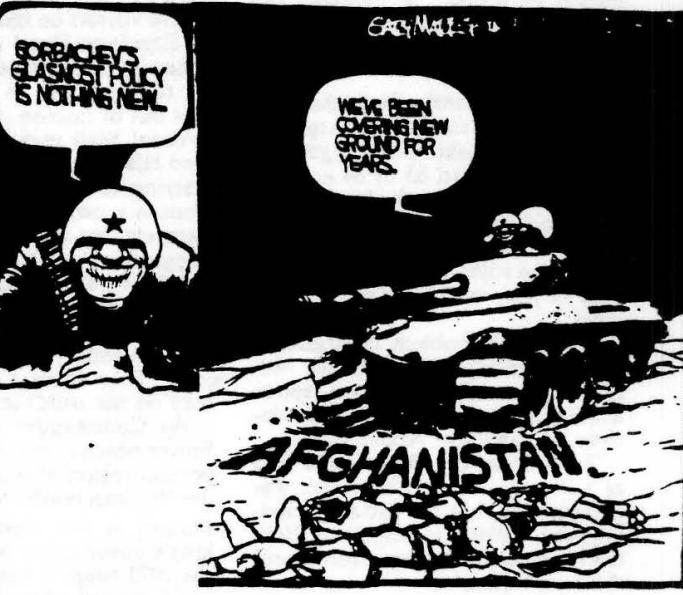

Soldier of Fortune. $4 / 88$

national tradition and social values through an allembracing creed comparable to the militant Isiam of Ayatollah Ruhollah Khomeini in neighboring I ran. They say this is so despite the fact 
Teneral Abdul Wali, the Sandhurst-trained son of the "Conqueror of Kabul", is variously deseribed by his enemies as sinister. over-embitious, and as thick as two planks.

More importantly, he is the minder of the last king of the Afghans, Mohammed Zahir Shah, aged 73. Abdul Wali, aged 63 or 64 - he is not sure - keeps such close tabs on the deposed king, who is also his cousin and father-in-law, that envoys denied the royal presence wonder, only in jest, whether Zahir Shah is alive.

The king's problem in Afghanis an and among the bulk of the Mujahedin resistance is that he is seen as a weak man dominated by his rela tives, in particular Abdul Wali.

Zahir Shah began his reign in 1933 as a 19-year-oid after his father was assassinated, but his uncles, including Abdul Wali's father, Shah Wali, the legendary conqueror, ruled until the king turned 40 .

In 1953, his cousins took charge of him. Twenty years later he was deposed by his most powerful relative. Mohammed Daoud (who in turn was killed in the 1978 coup that brought Afghanistan's leftists to power).

Even in exile. the king has not escaped his family's grip. While Zahir Shah remains a recluse reading French novels at his home in a sub. urb of Rome, Abdui Wali is his prime minister, cabinet secretary, chancellor, minister of war and foreign affairs and spokesman all rolled into one.

He alone determines who sees the king. He alone decides what the king will say publicly. Now that the former monarch is being courted by Russia, India, the US and, to a lesser extent. Pakistan to lead an interim extent. Pakistan to lead an interim withdrawal of the Russian army, the eyes of the king's relatives are beginning to sparikle.

You cannot see anything in Abdu Wali's eyes. They have the unblinking stare of a Pathan, though he does smile from time to time. However, he is very pukka, speaks with a clipped military accent and is ever so old fashioned.

He pulls out someone else's visiting card and says he would never have one with such a shine; his would

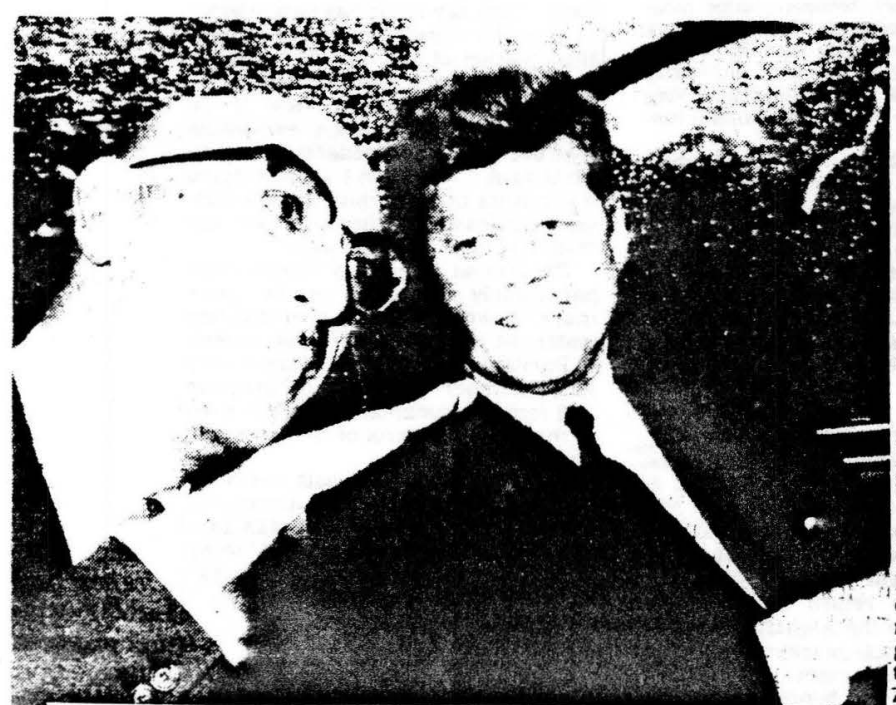

- KIng Mohammed Zahir Shah pictured with John Kennedy in 1963. The King now lives in exile and is seen as a weak man
dominated by his relatives, particularty General Abdul Wall.

ies such vulgar thing. obscurely that any cadet at a military

Forcestrander of the Centra Abduly written by pproached by Moscow was the kis

The key to any understanding of
Russinas bave gone.

He and the king's other relatives receive visitors on the Vin Veneto in the Excelsior Hotel or at the Cafe Doney - establishments which, like the royal family in Afghanistan, went of fashion in the $1960 \mathrm{c}$.

Abdui Wali uses the royal "we" when talking about the king, seldom referring to "His Majesty". Asked about his own ambition. he says college would not be worth his salt if

In Peshawar, where the general. leaders of the Afghan guerillas are based. Abdul Wali's ambition is a worry. They do not like his past and As Con trust anm. Forces which controlied the most imthe Pakistan border to Kabul, his in fluence in the capital and on the king's government was great. Until the 1973 coup, it was commonly be lieved he was after the throne.

Now his opponents fear he will use the ex-king to put himself in power. Until recently, Zahir Shah had reused to become involved in the conAbdur Wali, that he was willing to was the people's will. He said he had no ambition to restore the monarchy.

The Russians turned to him about year ago, hoping he would join their national reconciliation - an attempt that has since failed to broaden the base of the Kabul govUnfortunately for the approach. Abdul Wali, mereiy to have been of death. The insurgents already hold the king and his familv to blame for the first inroads of Soviet influence in the 1950s and 1960s. This, they argue, made the an interim govermment to supervise the Russian pull-out is that power. once taken, is seldom given up peacefully in Afghanistan. So the who leads it is likely to determine who will govern in Kabul once the
Abdul Wali knows this; the guerilla leaders know this and so do the Patristang who want a government in Kabul to their likins.

The three insurgent leaders who support the king. Pir Sayed Gaelani. Mohammed Nabi Mohammedi and Sighbattullah Mojadeddi, are traditonalists who prospered under the monarchy.

The four remaining guerilla leaders of the Mujahedin alliance gained nothing from the monarchy, indeed hey were persecuted or imprisoned for promoting fundamental Islamic

They fear that the king's supoor- ters will use him to take power. If you are looking to the king $a s$ the solution to Afghanistan's problems. you may have to turn your gane eter where. Rather than being a symbol of unity, he has unwittingly become a ymbol of division.

Among his fellow Pathans, there are some who see his rule as a golden era. But there seems no great love for him among Afghanistan's other tribes and races, such as the Tadzhiks, the Uzbeks and the Hazaras, who are fighting the war far from the comfort of $R$ ome and Peshawar. - The Independent

\section{HONG.SONG}

\section{STANDARDEXTR}

February 14, 1988

\section{Afghan Rebel Faction Leader Vows War Beyond Any Pact}

\section{BY HENRY KAMM}

ISLAMABAD, Pakistan, March 18 The leader of a powertul Afghan guer. rilla party and major recipient of covert American military assistance. whose aim is a "pure" Islamic state, consistently accuses the United States of conspiring with the Soviet Union against Afghanistan.

Yet the leader, Gulbuddin Hekma yar, denies that he is anti-American, as is frequently charged.

But there are people in America who are against our jihad," Mr. Het matyar said in an interview in Pesha war, the Pakistani city near the Afghan border that is the center for the seven parties fighting the Moscow-backed Government of President Najibullah in

"They are in the Government, in the parties, in the public," Mr. Hekmatyar continued, speaking in English. "There is a class of people who support our struggle because they are against the Russians, not as an Islamic struggie:"

Mr. Hekmatyar strongly opposes the Geneva talks on Afghanistan, with the United Nations acting as mediator be tween the Afghan Government and

"Gorbachev would not have made this announcement without an understanding with the United States," Mr. Hekmatyar said. "The Washington reaction proved that there is a secret conspiracy. If the Geneva accords are signed, you will find us on the battle-
fieid. $i$ personally will be inside Afghanistan."

The rebel leader, a 39-year-old former engineering student, who speaks in a solt but insistent voice with the certainty of a man expounding dogma. leads a wing of Hizbi Isiami, or Islamic Party. In the frequent discord of the loose guerrilla coalition. Mr. Hekmat. yar's wing of the split party stands out for being coherent and consistent.

Currently Leading Rebels

On Tuesday, Mr. Hekmatyar was named chairman of the coalition. The post rotates every three months amons the seven leaders.

Mr. Hekmatyar, who always wears raditional Afghan dress, preaches an slamic revolution. Unlike his fellow al. liance leaders, who strike above all an orthodox, anti-Soviet and anti-Commu. mist tone, he advocates a radical program that rejects a return to the traditional ways of Islam that dominated Afghanistan during the monarchy that was overthrown in 1973 and survived through the political struggles that preceded the move of Soviet troops into Afghanistan in December 1979 .

We want a pure Islamic state in Af. ghanistan," said "Brother" Hekma yar, as his associates refer to him. "Belore 1973? That was never an Islamic system. It was completely against Islam.

The leader was less forthcoming when asked to define the differences between the "pure" Islam he advo cates and the traditional system of the past. The rule of King Mohammad Zahir Shah, who led the deeply Mosiem country for 40 years, was not Islamic. Mr. Hekmatyar said.

"Islam says the ruler should be elected by the people," he said. "Not Zahir Shah."

\section{Purity bert No Detaile}

Unlike the other rebel leaders, Mr. Hekmatyar, who is aware of the impression his words make in the Westerm press, was reluctant to spell out his philosophy of "pure"

When asked about the application of Islamic law, with stern corporal punishment including amputation of limb or stoning to death of offending women, in all aspects."

Asked about education for women Mr. Hekmatyar said the Koran requires education for all. As for whether women should be educated like men as doctors, engineers or lawyers, he said: "There are some differences. Each class should be educated accord ing to its nature. It will be decided in the future.

Islamic fundamentalists believe that women should be educated for nothin out strict observance of the faith, with His favored treatment by Pakistan intelligence is believed to stem from the fact that he found refuge there at least three years before soviet troops moved into Afghamistan, and has since maintained close relations with the military and intelligence agencies.

A well-known Isiamic student leader at Kabul University, he fled here after an unsuccesstul uprising against the ansuccessful uphing against the President of the Government of President Mohammad Daud. Pakistan Presored him because of his opposition 


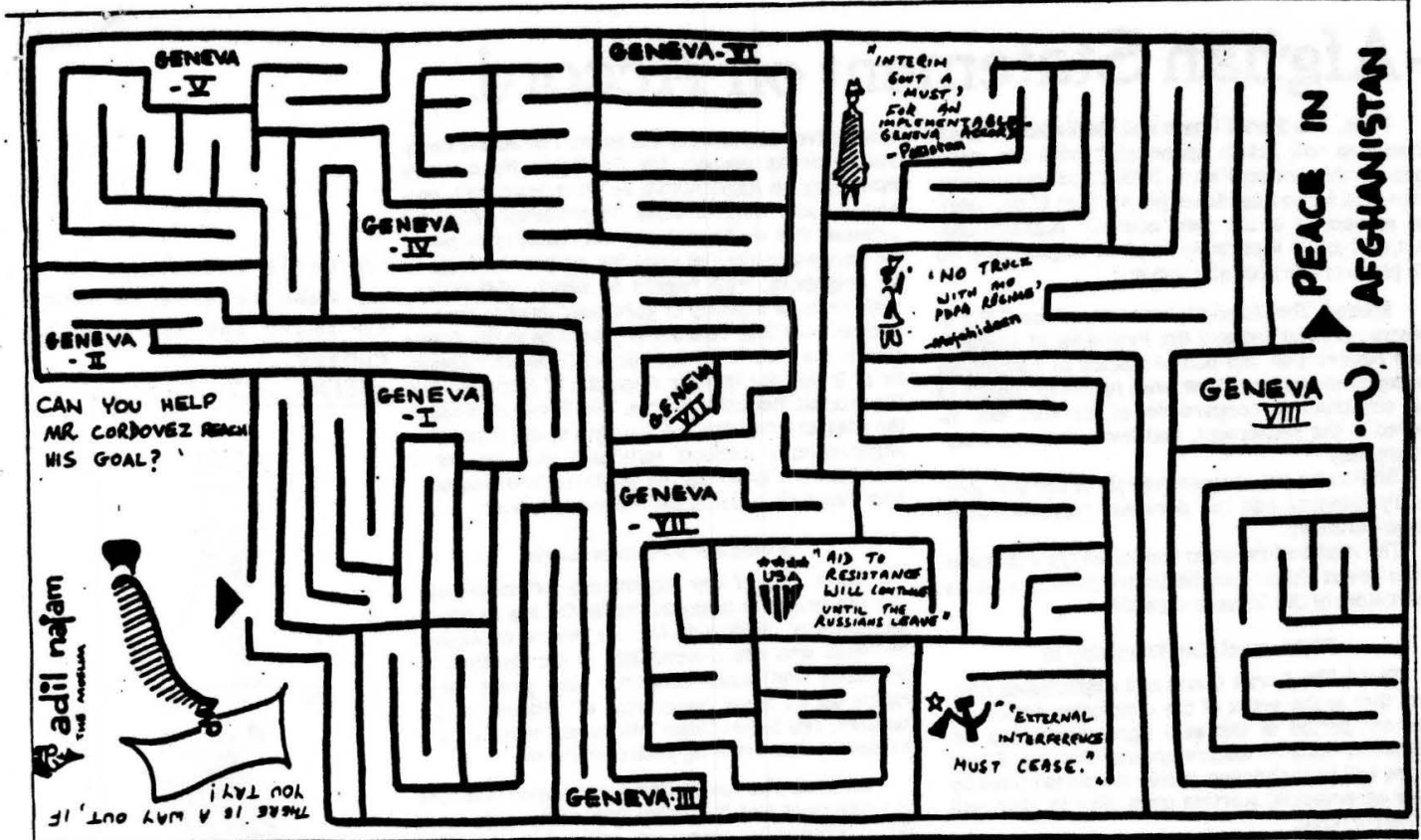

The Muslim 2/4

\section{Praise the Afghan Symmetry - and Keep Passing the Ammunition}

\section{By Rone Tempest}

SLAMUBAD, PAXISTAN

he successful Geneva negotiations on Afghanistan last week. calling for Soviet troop withdrawal, finally revolved around notions of "symmetry."

Not part of the Afghanistan vocabulary until recently, symmetry is the favorite new word of Reagan Administration officials and conservative politicians like Sen. Gordon J. Humphrey (R-N.H.), who visited the Pakistani capital last week to reassure himself that things were proceeding symmetrically regarding the massive American arms supply to Afghan rebeis. known collectively as the moujahedeen, or holy warriors.

The Humphrey idea, one shared by at least 76 of his colleagues, according to a Senate vote Feb. 29 , is that the United States, as a potential guarantor of the United Nations-sponsored talks between Pakistan and Afghanistan. should not close off its Central Intelligence Agency pipeline of arms to the morjochedeen until the Soviet Union has cut off its suppiies to the Afghan regime in Kabul.

Or, conversely, if the Soviet Union

Rone Tempest is The Times' correspondent in New Delhi. insists on continuing to supply the Naijbullah government, then the United States should likewise continue to supply the rebels. Either way, it would meet the definition of symmetry, at least in the current diplomatic context.

Now the Geneva negotiators have reached that accommodation, to allow both sides to keep the arms and aid flowing.

Actually, it is a mainly symbolic issue. Arms and ammunition are not in shor supply on either side of the conflict. according to military and political experts who have carefully observed the war here. Both the Kabul regime and moujahedeen appear to be awash in weaponry. Soviet Deputy Foreign Minister Yuli, $\mathbf{M}$ Vorontsov admitted as much to Pakcistan officials when he visited here Fet. 10.

"He told us the Soviet Union had given the regime plenty of equipment," a senior Pakistan official recalled recently. "He told us the problem was not equipmen but the ability of the regime and its troops to use it."

Western correspondents who visited Kabul in December saw huge warehouses and open air storage depots of new equipment. and witnessed dozens of cargo lanes arriving every day.

On the rebel side, the group that has complained most. vociferously. about a shortage of weapons and ammunition, the National Islamic Front of Afghanistan (NIFA), is famous among journalists for shooting off thousands of rounds of ammunition just to impress television cam. eramen. often miles from any potential fighting. A photographer for an American news agency recalled having to return to a Pakistan base camp with a NIFA contingent because the rebels had fired most of their ammunition before entering Afghanistan.

Meanwhile, credible intelligence sources have been saying for the past year that rebel groups were busy hoarding weapons, poesnbly in anticipation of renewed tribal warfare after the war ends. Even worse, some rebel groups are believed to have sold some of their weapons to Iranians and other forces not friendly to the United States, including the sophisticated and effective Stinger missiles used to down Soviet aircraft in Afghanistan

Nonetheless, both the Americans and Soviets appear to have been engorging their suppiy lines for months to rush in as many weapons as they could before the settlement was reached. The CIA program in Afghanistan, using Pakistan as a willing conduit, is by far the biggest American covert operation since Vietnam.

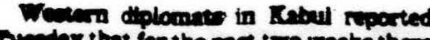
Tumbl that for the past two weets then hes been increased air traffle and large convoys of Soviet truckes moving into the city. "Many depart and leave under cover of dartunes." one diplomat said. "Afghan have reported heavy nighttime Soviet resupply operation

Since the arms-supply tape are open wide on both sides-aymmetrically as were-that should guarantee plenty of weapons to kill everyone in Afghanistan several times over. After all, its prewar population was only 15 million, and as many as 1 million may have died already.

While they have been fighting the Soviets, the loosely affiliated rebel forces have served U.S. foreign policy handily, embarrassing the Soviet Union and inpiring near-unanimous solidarity in the West on the Afghan isoue. Yet many of the stronger rebel groups represent fundamentaliat Islamic strains not dissimilar to those in Iran.

With one war apparently at an end, the same holy warriors that the United States has armed to the teeth could easily redirect their anger toward the West. Then how long should the United States continue supplying arms to the rebels?

An answer might be found in state ments Western officials made a month ago, before the "symmetry" issue muddied matters on the home front. In background sessions, senior Western diplomats insiated that the goal of continuing the weapons supply was somewhat limited, mainly to ensure that the moujahedeen had enough guns and bullets to capture Kabul and remove the Naibullah regime after Soviet troops withdraw.

A lot of steps will be taken to make sure [the moujahedeen! have enough on hand by May 15," one official said referring to the date announced by the Soviets as the beginning of a troop withdrawal. "If we felt the mouj couridn't take Kabul. there would be no Geneva."

For experienced American officials. including many. Vietnath veterans, the "fall of Kabul" is a shining vision. It would be a perfect reprise, they feel, to the fall of Saigon 13 years ago. Few veteran Afghan experts in the West, however, have high expectations for what might follow the fall of Kabul.

Given the nature and religious zealotry of many of the rebels, they feel, there might not be much profit in attempting to shape a post-Soviet Afghanistan. So the unstated program in U.S. arms aid to the rebels appears to be to shoot for the fall of Kabul. the perfect bookend to the fall of Saigon, and not much beyond

In that regard, perhaps the United States and the Soviet Union will have both learned, in the painful withdrawa process, some lessons about the folly of military intervention. Perhaps there will be symmetry after all.

LA Times

\section{Soviet Afghan Drive Called Decision of a Few}

By PHILIP TAUBMAN

MOscow, March 29 - Not long ago, Geurgi A. Arbatov, a member of the Communist Party Central Committee, described the day in December 1979 wept into Afghanistan.

Mr. Arbatov said he was recuperating from a heart altack in the Kremlin hospltal when a fellow patient, Anuloly F. Dobrynin, then the Soviet Ambassa. tor in washingion, phoned him fiom another ward

"You won't believe this," Mr Arba lov recalled his colleague sayıng. "but our soldiers have gone into Afghan The point of the story - that netther Mr. Dobrynın nor Mr. Arbatov were consulted about the decision or knew of it in advance - was consistent with tervention as an act approved by only a small circle of Soviet leaders, perhaps no more than four or tive Mr Dobrynin is now a Central Comittee secretary and one of the party's down the war, made sometime in the senior foreign policy advisers. Mr. Ar- last two years, was as painful as ceratov, long a specialist in American af- | tain Soviet officials suggest, reportedly balov, long a specialist in American asUnited dialector of the insti As the Suviet Union has moved in reent munths to reduce its military inyeurs of war, bits and pleces of information have begun to appear indicat here, and even a degree of opposition, from the start.

It is 100 early 10 know how much internal dissent there was, or exactly how it influenced the eventual decision
to seek a political settlement and the withdrawal of Soviet troops.

Because a decision to withdraw miliLary forces has apparently been made. creasing criucism, some of the new in furmation may be designed to distance officials from a discredited policy. What does seem certain is that the Soviet Union is begınning a public reappraisal of country's leading economists, Oleg T. Bogomolov, a key Gorbachev adviser and director of the Institute of Economics of the World Socialist System. the weekly Literaturnaya Gazeta, Mr. Jan. 20, 1980, less than a month after the Soviet troops were sent into $A$ ghanistan, outlining 10 points of objecion to the intervention. volvement in Afghanistan after eigh and the intervention is likely to face in-
The letter, according to Mr. Bogomoov, said in part, "The geographical and sociopolitical conditions are unfavorable, and we will have to deal with the united resources of the United States and other NATO countries, China, Australia, the Islamic states and an army of Afghan insurgents." Another point the letter raised, Mr. Gorbachev's adviser said, was that the intervention would undermine a trend toward improved relations with the United States and create a political at-

praisal of the war that will produce a
good deal of revisionist history. Other top Soviet officiais have told Westerners that the decision to send roops into Afghanistan was made by a handful of senior members of the Cum. munist Party Politburo. Bopomolov reported that his institute fired off a protest to party leaders on
Robert Legvold the directar of the Harriman Institute for Advanced Study of the Soviet Union at Cotumbia University, said durinon at casumbia University, Said during a visil to Mosthat no more than four or five officials were more

$\mathrm{Mr}$. Legvold said the men included Leonid I. Brezhnev, who led the Soviet Union trom 1964 until his deach in 1982 . Dmitri F. Ustinov, the Derense Minis.

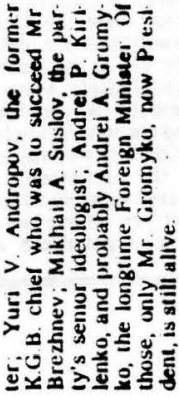




\section{Text of the Soviet-Afghan Statement on Accord}

Following is the text of a joint statement issued yesterday after a meeting between Mithail S. Gorbachev, the Soviet leader, and Najibullah the Afghan lecder, in the Soviet Central Asian city of Tashikent, as released in transiation by the Tass press agency:

A meeting between the General Secretary of the C.P.S.U. Central Committee, Mithatl Gorth chev, and the President of the Republic of At shantstan, General Secretary of the Central Committee of the People's Democratic Party of Afghanistan. Najibullah, was held in Teshkent on April 7, 1989. Taking part in it were:

Member of the Political Bureau of the C.P.S.U. Central Committee, Miniteter of Foreign Affairs of the U.S.S.R., Eduard Shevardnadre, and the First Secretary of the Central Committee of the Com. munist Party of Uzbekiatan, Rafik Nishnnov.

Mikhail Gorbachev and Najibullah exchanged views on the key moments of the international situation and studied in detail topical questions directly concerning the interests of their countries.

They noted that the policy of national reconciliation conaistently pursued by the Afghan leadership, its constructive position on questions of the political settlement is the oany correct tine that ac. cords with the interests of the Afghan people, all of its neighbors and the interese of the entire beterrational community.

Loyalty and Nonintertarence Padecel

The sides confirmed loyalty to the old tradition I building relationis between the U.S.S.R. and Athaniztan on principles of equality, mutual re ect, mutual advantage and noninterterence in inmal affairs.

As a result of the meeting. Milchail Gorbachev 1 Najibullah arrtved at a common view on the bwing.
First. The Sovide Union and the Republic of A hanistan will ect in accordance with the state ments published on Feb. 8, 18st. These matements imparted a new impulice to the process of the polith cal cettiement of the most complex redional con nict and made it posaible to place nepotiations on the plane of a prectical solution

Second. The General Secrecary of the C.P.S.U. Central Committee and the President of Afthanistan believe that the lan oberncles to conchudin the agreements have now been removed thanks to the constructive cooperation of all who are in olved in the settlement, and favor their immedi. ate signing

Boch sidas duly aseess the role of the U.N. SecDieng Cordover

The Alethan of the Soviet Union and the United States to act as guarantors of the Geneva accords.

\section{Withdrawal May Sean May is}

Third. The Soviet Unica and Afthanituan reaf. firm that in the event of the conchusion within the tortest partod of the said asreemems, the Athanistan-USS.R. understanding that the Soviet troepe will be withdrawn within the period fred by these agrosiness, starting from May 15, 1988, will remain in farce.

Fourth The policy of antional reconciliation makes it posatble to settle the situation around $\mathrm{A}$ ghanistan, end the war and fratricide, eanblish peace throughout the country's territory and form a coalition government with the pardictipation of all forces representing Afghan socioty, inchudtus those who are currently opposed to one anocher.

Fith. The final etaus of their coumtry amoes other states will be determined by the Aithans themeetves and nobody but them. The Soviet Union reaftirms its apport for Prealdeat Najibullah's ctatement on Afchanisten as an indepeadeat, nonaligned and neutral stace. It proceseds trom the prembe that the territory of that country or any of its part will never be used for purpeses homtle. its neterhbors, with reeard to which Af mannis. will continue a policy of good-netphborty reiatio and cooperation. This equally applies to the Sovte Union, the People's Republic of Chima, the Republic of India, the Ialamic Republic of Pakietan and the Isiamic Republic of Iran. The Soviet side backs the Afghan President's atatement to the effect that Afghanistan's internal structure will rest on. multi-party syotem in the political flold and on multi-ectoral basis in the ecosomic epphere.

\section{Refupenos Return is Souch}

Sixth. It is of key importance for implemeat. ing the policy of national reconctilintba to create satisfactory conditions for the returs of Afritan refugeas who are temporarily in the terrttory of Pakiatan and other countries and grant thom rights on an equal basis with all citions of the country. The Sovier Unioa will extend acatetance to Afchanistan in creating auch conditions.

Seventh. The Soviet Union, relying on relations of traditional and historical iriendehtp, expreases the readiness $t 0$ cooperate with Afghaniscan a high level in order to restore the economy and facilitate the economic and social development of the Republic of Afghaniman.

Elghth. The General Secreuary and the President call on other states to contribute to establishins peace and national reconciliation in Afghanistan and respect the Geneva accords. This would set a good and encouraging example for resolviay other regional connicts.
'Notable Moscovite rrying to make believe he means to leave the spot he occupies."

AFGHAN INFO $2 / 88$

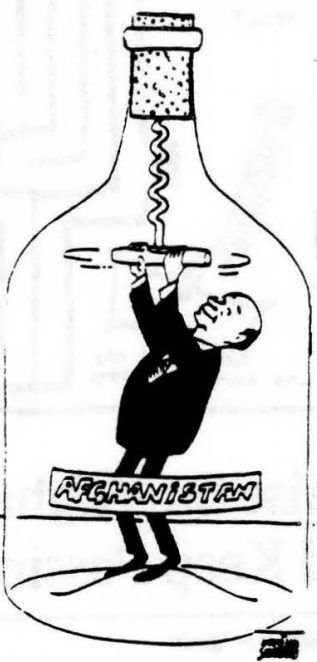

\section{U.S. and Soviet Would Suspend Arms Shipments After an Accord}

\section{By PAUL LEWIS}

Special to the Now Yort Times

GENEVA. April 7 -. The Reagan Administration and the Soviet Union intend to suspend all arms deliveries to Afghanistan after the conclusion of an agreement of a Soviet troop withdrawal, knowiedgeable officials said today. The suspension would last for at least
nine months, the time that the Soviet Union will have under the emerging agreement to remove its 115,000 troops in Afghanistan on the side of the Communist Government there, the officials said.

But Washington and Moscow will reserve the right to resume military supplies to the faction it supports in the civil war if the ocher superpower breaks the informal agreement and re sumes sending arms into Afghanistan these officials say.

The private agreement means that Moscow can plausibly argue that its longstanding cooperation agreement with the Govermment in Kabul will nox be interrupted by a troop withdrawal negotiations.

The Reagan Administration can oqually say it is not selling out the guer. pilies.

U.N.'s View of the Understandtan

But the United Nations Secretary General, Javier Pérez de Cuellar, plan to state that in his view the United States and the Soviet Union are obliged to stop all military aid to the warring Afghan factions indefinitely when the withdrawal agreement is concluded according to United Nations officials. The Secretary General will say that two superpowers are bound to support its aims and objectives, which include promoting peace in Afghanistan and

\section{The informal agreement will provide for rearming.}

ending the civil war. Further arma hipments to the combatants the violate the spirit of the accord. this position partly to increase interma tional pressure on the United States and the Soviet Union to respect the arms cutoff and to promote a political settlement between the Government in other Afghan politica

ations officials say. counter accusations that ' the United Nations-backed agreement, as it is now emerging may do little to promoce lead to a Soviet military pullout

This is because the private agreement between Washington and Moscow came only after they sent large amounts of weapons to thoir clients in Afghanistan in recent weets, thus ena. bling the factions to contimue the civil war after the Soviet forces leave, officials in Geneva say.

On Wednesday, Senator Gordon J. Humphrey, atter retuming from a visit to Pakistan, said the guerrillas were being resupplied on a subetantially greater scale than in the past. The New Hampshire Republican, who is a leading Congressional backer of the guerrillas' cause, also reported that the guerrillas are receiving new supplies the Stinger anti-aircraft missile, planes and helicopter According to West German press re ports, the guerrillas are also receiving agreement to suspend all weapons supthe French-West German Milan anti- plies between the United States and the tank rocket, which has not been soid cank rocket, which has

Earlier attempts by Pakistan to link But Moscow rejected this idea bearthe cause it threatened to interrupt its ation of a colition government in Government-to-Government agres Kabul have been abandoned lareety at ment with Kabul.

Kabul have been abandoned larely at iration, which considers a Soviet milicary pullout its priority in the negotia cions, officials say.

Instead, the participants in the ne otiations have reached a vague agree ment under which Diego Cordovez the United Nations mediator, will seet to promote a new political dialogus be ween the Afghna factions aft Angutaly in U.N. Debates

The possibility that a United Nationssponsored agreement might do nothing to stop the fighting has prompted anguished debate among senior United York. according to some of those in volved in the discursions.

These officials feared that the United Nations would further damage its reputation if it is seen as sponsoring a withdrawal at the price of a wide-scale rearming of both factions that

Many United Nations officials are Many United Nations officials are
also unhappy with the private agres. also unhappy with the private agreeend further arms deliveries.

The Secretary General's planned declaration opposing resumed arms deliveries is thus seen as a way of prolecting the United 'Nations againat charges that it has done little to end the civil

The milltary supply issue has proved the thomiest yet in the current round of negotiations here. Originally, the Reagan Administration wanted a formal

But the two sides have now agreed on what is called "positive symmetry," which allows them to continue suppliea at equivalent levels, but with a private zero.

"Positive symmetry does not mean continuing supplies," a United Nations official said today. "That is the understanding given the U.N."

Fears of a continuing civil war have increased because the guerrilla leadership has rejected any compromise with Kabul and is demanding the end of the Communiat regime. But United Natons negotiators here believe the guerrillas will become more flexible after the Soviet forces leave. They also say that Moscow and Washington can probably bring pressure on both sides to compromise and begin searching for a political solution.

But a senior Pakiarani official here cook a different poattion tonight, sug. gesting that the "moral isque" in the negotiations is not to end the war, but to decide "who is the legitimate government of Af ghanistan."

Abdul Sattar, the chief civil servan in the Pakistan Foreign Ministry, said that United Nationse-sponsored agree 
Exit Card for Af then Officials

$A$ card that appears to provich for the evecuation of Afghan offcials in the eveat of a Sovier mill tained by Frevedon Bouve, a Ne York-besed erranicention monitos. ing political and human rights. The card, 3 by 5 tnches, bears the title "Permit for Special Evacuation" and is imprinted with a red star and a hammer end sickle. It is prtated in Russian on one side, and Persian on the otber. The card is "otensibly to be used by high-ranictos Communist and Afghan officials on the oces. sion Soviet troope be withdram from Afghanistan," said Ludmilla Thorne, a Soviet specialist.

Ms. Thorne said she received a copy of the card from an Amercopy of the card from an Amer-
ican friend who said he had received it from Alghan insurgent forces on a visit to Peshawar, Pakistan, where the insurgents have their headquarters

The card begins with the word. "Comrade," followed by a blank space, where the name of the holder can be inserted, and continves, "is granted the righe of special evacuation by air and land

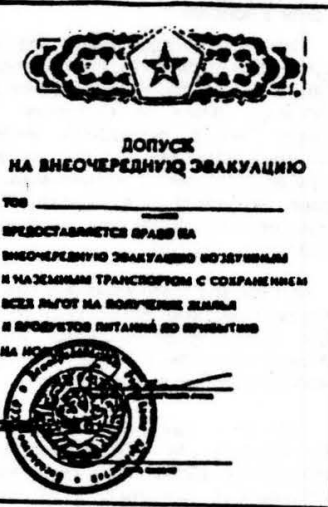

all privileges for receiving a place to live and food upon arrival." That is followed by spaces for the signature of "a person of auchority" and a "date of issue." The olficial stamp of the Embassy of the "U.S.S.R. in the Democratic Republic of Afghanistan'" appears on the bottom left portion.

NYT $4 / 7$

\section{Annual Survey of Afghan War for 1987}

An annual survey by Agency riers were destroyed, as well as Afghan Press Pakistan shows that casualties increased by $10.7 \%$ in the 8th year of the Afghan war. During Mujahideen operation and clashes against the occupying forces 9,217 Soviet-Afghan soldiers died, $52 \%$ being Soviets.

The number of Mujahidee casualties was 2,059 martyred (4\% increase on 1986) and 3,158 injured. 4,781 officers and soldiers of the Afghan Army defected to the Mujahideen (35\% increase on 1986). On the other hand, 1,913 Aghan Army soldiers surrendered to the Mujahideen and the number of deserters from the Afghan Army is much greater than this.

In 1987, the Soviets lost 251 planes and 211 helicopters (300\% increase on 1986). Also, 813 tanks and armored personnel car
1,262 oil tankers, supply trucks and military vehicles. The Mujahideen captured 257 heavy machine guns, cannons and other heavy weaponry, and 8,128 automatic rifles.

An estimated number of 22,294 Afghan civilians were martyred, $90 \%$ being women, children and old men, while 24,671 civilians were seriously injured. The year saw the destruction of 2,622 houses, mosques and places of religious significance. The second largest Afghan city of Qandahar took the brunt of destruction and a major part of the city is now in ruins. In Kabul, Mujahideen operations were stepped up from 1986.

A significant event which took place in 1987 was the Mujahideen operations inside the USSR.

\section{Afghan officials reportedly selling homes and sending families abroad}

By Marc Kaufman

NEW DELHI - Leaders of the Soiet-backed Afghan government are eginning to sell their homes and send their families abroad amid rowing indications that a Soviet troop withdrawal will begin soon Western diplomatic sources said ere yesterday.

Some senior Afghan Communis Party and government leaders have sought refuge in socialist countries. Castern bloc diplomats have re orted. and rumors of such deparures are all around Kabul.

The sources also said that Sovie roops bad stopped patrolling some of the main Afghan highways they kept open for years, leaving the b to the Afghan military. And there ave been unconfirmed reports that Afghan troops are beginning to tak p important defensive position round Kabul.

In addition, the sources said, the royal palace in Kabul is being pre rored for a possible return of the ormer king, Zahir Shah, whom the
Afghan government and some restatance groups would like to see in stalled as the head of coalition government. Zahir Shah has been living in exile in Italy since be we verthrown in 1973

While the Soviets and the Afghan government apparently are prepar. ing for a withdrawal, the sources said. mujaheddin resistance fighters have stepped up their attacks in $K$. bul and seemed to be massing in the valleys north of the capital.

In Kabul, there were reports of 1 major explosions last week. including several inside the Soviet $\mathrm{Em}$. bassy compound and one at the $A$. ghan radio-TV complex. The explosion at the complex, source said. seemed to be from a large car said. see

Soviet troops moved into Afghanistan in 1979, and there are now an estimated 115,000 Soviet troops inside the country. The mujaheddin bave carried on an increasingly successful guerrilla war against the Soviets and their Afghan allies, with sub stantial aid from the United States for the last few years.
Negotiations to end the Soviet milicry preance have been going on for years under U.N. anspices. The next round begins March 2 , and Soviet leeder Mikhail S. Gorbachev has said that if an agreement is reached by March 15, Soviet troops will begin leaving by mid-May.

No arrangements have yet been made for an interim government in Kabol after the withdrawal, and the mujeheddin have rejected any proposals that would leave the current communist government with a substantial role.

The massing of mujaheddin forces in the Panjshir and the Logar Valleys to the north and northeast of Kabul may be a prelude to a concerted artack once the Soviets have be gun to leave, the diplomatic sources

Three days after Corbachev an. nounced that Soviet troops would begin withdrawing from Afghani. stan by mid-May, the sources added. the Soviet ambaseador to Afghan. stan, Padel Mozhaev, had a serious stan, Padel Mozhaev. had a serious
heart attack and was nown to Moscow.

\section{Comparative prices of goods in Kabul: AICMB 非84

\begin{tabular}{rr} 
Last Year & Current Year \\
\cline { 1 - 2 } Afs. & Afs. \\
280 & 550 \\
250 & 280 \\
30 & 80 \\
130 & 220 \\
120 & 240 \\
600 & 800 \\
2,000 & 2,500 \\
14 & 30 \\
14 & 14 \\
6 & 6 \\
700 & 900
\end{tabular}

Kayhan Int'1

\section{Soviet Defectors Relate Afghan Trauma}

\section{By ERIC LICHTBLAU. Times Staff Writer}

WASHINGTON - Two Soviet defectors Wednesday offered a care glimpse of life in the Red Amy in Afghanistan in hopes of gaining political asylum in the West for several hundred other Soviet soldiers thought to have deserted or been captured by the Afghan rebels.

Their Capitol Hill testimony described the disillusionment that led hem to flee their assignments in he Soviet intervention in Afghanitan. Many members of Congress, meanwhile, are trying to pressure the Reagan Administration into setting up a "defector pipeline" to encourage disaffected Soviet soldiers to seek U.S. asylum.

"Having Soviet soldiers defecting in large numbers and telling heir stories in the West will put substial pressure on the Soviets withdraw," said Rep. Don Ritter (R-Pa.), a member of the Commissiov on Securty and Cooperation in
Europe, which conducted the hearno "And we will bring to freedom hundreds of young men who most likely face punishment or death if they are forced to return to the Soriet Union."

The governmental commission was formed in 1976 to monitor compliance with the Helsiniki human rights agreements signed by the United States, the Soviet Union and 34 other nations in 1975

In a moving statement at the hearing, a Soviet electrician. Igor Kovalchuk, described his frustra tion and depression over being "sucked into a huge bloody whiripool" of violence as a Soviet sharpshooter in Afghanistan.

Kovalchuk, 27, said that growirig up in the city of Kharkov, "I was taught to believe that our system was the best and the most humane in the entire worid, while Ameri cans were egotistical exploiters of ther people, who want to take over the world and keep it in their own hands."

But after being drafted to fight in Afghanistan, Kovalchuk said, he began to grapple with questions about why the Soviets were there. He quoted a Soviet officer as telling his troops: "Stop your bab. bling. . . . American mercenaries are on the territory of Afghanistan and it is our duty to get them out of there, understand?"

Kovalchuk told commission members he "smoked dope," cried to himself and sometimes closed his eyes when shooting someone at close range.

Finally, after a small girl was killed by his unit, Kovaichuk decided to escape in 1982. he said. He joined and fought with the Afghan resistance and four years later won asylum in Canada.

Similarly, Sergei Busov described "the lying, the thievery, the servility and the crueity" that he sard prompted him to flee the Soviet army for the foothills of Afghanistan in October. 1983.

Ludmilla Thorne, a Soviet hu19

man rights specialist in New York 


\section{Arming Afghan Guerrillas: A Huge Effort Led by U.S.}

\section{BY ROSERT PEAR}

WASHINGTON, April 17 With help from China and many Moslem nations, the United States led a huge international operation the AIghan guerrillas with the weapons they needed to drive the Soviet Army from their country.

The operation is one of the big. gest ever mounted by the Central Intelligence Agency, according to American officials and foreign diplomats. It dwarts American ef forts to aid the Nicaraguan rebels. but its details are much less widely known because it encoun-

Cost Totals $\$ 2$ BIIIIIon

Indeed, Congress was continually prodding the C.I.A., the Join Chiefs of Staff and the State De partment to provide more support for the Afghan guerrillas, who limped along with relatively ineffective weapons until they got Stinger antiaircraft missiles in September 1986. They used the missiles to shoot down armored Soviet helicopter gunships, and as a result, the guerrillas and their supply caravans have been able to move with much less lear of being attacked from the air.

As Afghanistan and three other nations signed agreements last week providing for the with drawal of Soviet troops, these de. tails of the supply operation emerged from interviews with members of Congress and off1cials at the White House, intelligence agencies, the Defense De partment, the State Department and the Office of Management and Budget:

TArming the rebels has cost the United States more than $\$ 2$ billion over eight years, although the exact amounts of appropriations are secret because the operation is not officially acknowledged by Washington. The program has had strong bipartisan support in Congress throughout.

TThe Government of Saudi Arabia has generally matched the United States financial contributions, providing money in a join und with Washington to buy hundreds of Stingers for the Islamic guerrillas even though Congress would not permit such sophisticated weapons to be sold to the Saudis themselves. In addition, several wealthy Saudi princes, motivated by a sense of religious duty and solidarity, gave cash cont ributions to the guerrillas.

9Tennessee mules have made an invaluable contribution to the guerrillas' campaign, transporting tons of equipment, food, cloth ing and medical supplies acros the frontier from Pakistan int Afghanistan. Hub R. Reese Jr. of Gallatin, Tenn., who runs what he describes as the world's largest mule trading and auction compa ny, said that in the last year he de livered 700 mules to an Army base in Kentucky for shipment to Pakistan.

9China, which has a short bor- ler with Afghanistan, "worked hand in gove with the United States" in supplying the guerrillas with rocket ianchers and other weapons, accord the American Embassy in Beijing But Jan, which often portrays itself as a deader of the Islamic world, provided tery hmited, intermittent support to the goverrillas, who call themselves mujatedeen, or "holy warriors."
Administration officials cite their for President Reagan's policy of help. ing indigenous groups resist Commu ins flicts. But many officials were initially reluctant to provide vigorous support for the Alghans, fearing that it might unrealistically raise their hopes for a military victory or provoke Soviet reprisals against Pakistan, the main con duit for aid to the guerrillas.

Stansfield Turner, who was Director of Central Intelligence under President Carter, said some intelligence professionals believed the United States less cause.

Fred C. Iklé, an Under Secretary of Defense from 1981 to February of this year, said that in the first three or four years of the Reagan Administration. "there was a general shyness and hesitation, a reluctance to make a more concerted effort, to provide more in-
struments and tactics to freedom fight-

ers in Affhanistan." Iution saying "It would be indefensible to provide the freedom fighters with only enough aid to fight and die, but not ennugh to advance their cause of freedom."

The measure had been introduced Tsongas, a liberal Massachusetts Democrat. Senator Malcoim Wallow, a conservative Republican from Wyoconservative Republican from Wyo-
ming, wrote in 1984 that " the only opposition to the resolution has come essen lially from the C.IA and the Depart. mept of State

senator Gordon J. Humphrey, a New Hampshire Republican who is chair man of the Congressional Task Force on Afghanistan. said in an interview this week. "The C.IA was very reluc tant in carrying out its responsibilities for the longest time " But he and other lawmakers gave the agency high
marks for running a much more efficient operation in the last couple of

Inferior Arms in Early Program

What follows is a history of that nperation, as described by people

More than 30,000 soviet

moved into Afghanistan, with plapes and tanks in the last week of planes ber 1979. On Jan. 1, 1980, the Soviet Government newspaper Investia charged that the Central Intelligence Agency was "directly involved in training Afghan rebels in camps in Pakistan." The State Department refused comment.

In mid-February of 1980. Egypt's Dereace Minister, Lieut. Gen. Kamal Has 3ill Ali, said his country was tratining Aighans in guerrilla wartare and mould send them back to their horneGornment At about the same time corernment. At about the same time, White House officials said ereadent Carter had approved a "covetcperation" to supply the guerrillas small arms of Soviet design. inFor five years, American officials provided the guerrillas with weapons designed and manulactured by the Soviet Union or other East Bloc coun. Iries so they could deny that the United Stales was supplying such assistance. They could maintain that the guerrillas had captured the weapons from the Af.
ghan Government or from Soviet ghan Government or from Soviel

But that strategy created immense problems for the guerrillas. "For mos of the first five years of the war. the mujahedeen lacked any effective an Alexander R Alexiev of the Rand CorAlexander R. Alexiev of the Rand Cor who has analyzed the war in affairs an under a Pentagon contract. "Despite the presence of vastly superior weapons in Western arsenals," he said. "the resistance was supplied craft machine guns that were hardly a

match for ine neavily armored and deadly Soviet gunship helicopters. On the ground, the rebels' main long-range weapon was the Soviet-model 82-millimeter mortar, not known for either sult, the Soviets enjoyed virtually unchallenged dominance in the air."

First Reagan Effort Falts Short

When Mr. Reagan took office January 1981, his appointees were told that support for the Afghan guerrillas was the most significant covert oper ion being conducted by the C.I.A

In the fall of 1982, the President de cided to increase the quality and quantity of arms supplied to the insurgents. In December, the agency was ordered to provide them with bazookas, mor tars, grenade launchers, mines and re coilless rifles. But guerrillas on the batprovement in the flow of arms.

Andrew L. Eiva, chairman of the Federation for American Afghan AC tion. a private group that lobbies for military aid to the insurgents, said that through 1984 they were still gettin weapons of relatively poot quality. like Soviet SAM-7 antiaircraft missile. Fven when they got good weapons, like the 12.7 -millimeter heavy Soviet ma the 12.7 -millimeter heavy Soviet ma
chine gun known as the Dashaka, they did nol get ncarly enough ammunition defend themselves against Sovie helicopters, according to Mr. Eiva, who was an Army infaniry officer in the Green Berets in the 1970's.

In the fall of 1983, Representative Charles Wilson. Democrat of Texas, started a campaign to supply the guer rillas with a more effective antiair craft weapon. "Opposition to the Stinger was so great that we had to se' he said, recalling that even William $j$. Casey, the Director of Centrai inteiiigence, would not push for Stingers. At the end of 1983, Mr. Wilson per-
suaded his colleagues to provide S40 suaded his colleagues to provide $\$ \mathbf{S 4}$
million for weapons, and much of it million for weapons, and much of it
went for a powerful 20 -millimeter aniaircraft gun made by a Swiss compay, Oerlikon. The guerrillas began to get the automatic cannon in late 1984. Mr. Wilson said in an interview.

In January 1985, Congress formed the Task Force on Afghanistan to investigate the guerrillas' needs and to put more pressure on the Administra-

A turning point came in April 1985 when $\mathrm{Mr}$. Reagan signed a classified order clarifying the goals of the covert operation. One goal was to get the
Soviet troops out of Afghanistan "by all means available," it said. That declameans available," it said. That decla-
ration eventually cleared the way for the C.I.A. to supply Western-made weapons to the guerrillas.

The budget for the covert operation more than doubled, to $\$ 280$ million in the fiscal year 1985 from $\$ 122$ million in 1984, according to members of Congress. In 1985, the guerrillas goe their first effective surface-to-surface weap ons, 107-millimeter multiple rocke launchers made in China. They have a range of about five miles, so the guerrillas could fire on Soviet and Afghan Government installations from a safe distance.

Nevertheless, according to Mr. Alexlev, 1985 was "the bloodiest and most difficult year of the war for the mujahedeen." After Mikhail S. Gorbachev became the Soviet leader in March 1985. Soviet forces dramatically increased the number and intensity of civilian population guerrillas and the sives continued into the spring of 1986 .

In February 1986, in his State of the Union Message, the President seemed to step up America's commitment to insurgent forces in the third world Paraphrasing a line from the Tsongas resolution passed by Congress in 1984. he said: "You are not alone, freedom lighters. America will suppori you with moral and material assistance your right not just to fight and die for fier

dom, hut to fight and win freedom

For several months, conservative groups supporting the guerrillas had harshly criticized John N. McMahon who was Deputy Director of Central in blocking efforts to send Sthat he was guerritlas. In early March Reagan approved deiivery ol such missiles. 
viet border.

Initially, 300 Stingers were allocated to the mujahedeen in 1986, with a further 600 in 1987. A number of these were captured in the first few months of their deployment. Some were turned over to the Afghan military by mujahedeen commanders who took advantage of the $\mathrm{K}$ bul governmnent's amnesty program, which includes generous cash payments for such weapons as Stingers and British supplied-Short Brothers Blowpipe surface-to-air missiles.

There have been continuing rumors in. both Pakistan and Afghanistan that approximately 16 Stingers were sold to Iran in 1987 by commanders of the Islamic fundamentalist faction Hezb-i-Islami for approximately $\mathbf{S I}$ million. This is denied by other mujahedeen leaders, who claim that the missiles, if they were obtained by the Iranians, were stolen from mujahedeen units. Batteries for use with the Stinger missiles were found on board a boat operated by the Iran Revolutionary Guards in the Persian Gulf on Sept. 21. 1987.

In addition to the Stingers, about 300 British-supplied Blowpipe missiles were provided to the mujahedeen through the same channels as the Stingers. These ar rived in Afghanistan in early 1986, before the first Stingers were received. Training was the responsibility of the U.S., and the muhajedeen apparently never gained confidence in the weapon, which uses a lineof-sight guidance system and is somewhat more complicated to operate than the Stinger.

The kill rate of the Blowpipe was low in comparison to the Stinger and its use has been terminated.

\section{Rebel Missiles Feared}

\section{By ROBERT C. TOTH and MICHAEL WINES, Times Staff Writers}

WASHINGTON-The U.S. weapons that many believe turned the tide against Soviet forces in Afghanistan-Stinger anti-aircraft missiles-are now causing "serious concern" that they will fall into the hands of Iranian or other terrorists when the Afghan war ends, senior U.S. officials said last week.

Many hundreds, perhaps more than 1,000 Stingers have been shipped to the region since mid. 1986 when the decision was made, under considerable congressional pressure, to provide the weapons to Afghan moujahedeen, the Musiim guerrillas fighting the Kabul government and Soviet occupation troops. Between 100 and 200 Sting ers are believed to be in guerrilla hands inside Afghanistan at pres ent, and one U.S. official has sug gested that there is the potential for $20 \%$ of them to be lost.

Even a few Stingers in terrorist hands could pose great danger to civilian airliners. Portable, shoulder-launched Stingers that home in on the exhaust heat of jet aircraft have been called "the perfect terrorist weapon."

Authoritative Administration of ficials Saturday denied published reports that Stinger shipments to the Afghan guerrillas have been cut off in anticipation of a peace ettlement being negotiated.

Other sources said the entire 1988 Stinger consignment has already been delivered. The rest of the military aid consignment, esti-

mated to be worth $\$ 300$ million, has also been filled. No cutoff in aid is contemplated until a settlement is chieved, sources emphasized.

"The Stingers not now in moujahedeen hands (those in the weapons pipeline or in storage in Pakistan| we can get back, but the rest we have no control over" said Richard L. Armitage, assistant defense sec retary for international security affairs. "It's been a concern steadily," he added.

In fact, according to a senior U.S. official, the danger that is now causing anxiety here was a major reason why the CIA initially objected to providing the weapons to the rebels. The Pentagon also shared this fear and suggested that the missiles might be too complicated for them to handle.

\section{Fantantle Suceese}

However, the rebels proved ex cedingly adept in using the weapons. "They've had a fantastic success rate, averaging maybe one aircraft a day for the past year." one senior official said. "Withou the Stinger, I doubt the Soviets would be leaving I think this weapon has turned the tide."

Use of the ground-to-air missile s easier in Afghanistan than other areas for several reasons, he explained. There are no friendly aircraft in the skies, so identifice tion of friend or foe is no problem. And the mountainous terrain favors those with Stingers, because the rebeis can get above the air craft attacking in the valleys and because there are limited landing places even for helicopters.
"It's good ambush territory," the official added, "but these moujahedeen actually go after the aircraft. They go to where the aircraft are based and taking off rather than wait for them to come to attack," he said admiringly.

U.S. officials hope that with the end to the Afghan conflict, the guerrillas will find little use for Stingers and may return them, or even trade them for more useful weapons such as light machine guns, in a "buy -back" scheme.

The moujahedeen are now divided among at least seven majo groups. "Once the various factions fall to squabbling among themselves - or once there's a coalition government, if that happens - machine guns are going to be much more important determinants of political power than Stingers," one source said.

But Armitage said the Afghan guerrillas' affection for the Stingers means they will keep the weapons at least "in the near term. In the long term, we don't know," he said.

Moreover, there are various models of the Stinger. The basic "plain vanilla" model, one source "paid needs two batteries to operate. Each battery has a one-year life expectancy, and the batteries are not readily available in the region. Only the Saudis and the Israelis could provide them, he said.

But terrorists have shown them selves excellent improvisers in such circumstances in the past, and U.S officials knowledgeable about the Stingers fear that the weapons that won the war against the Sovie invaders will "turn around and bite" the United States and the West in the future.

\section{Los Angeles Gimes}

March 27, 1988 Afghan Rebels

Abramowitz and Undersecretary of State for Political Affairs Michael Armacost be gan pressing the CIA to supply Stingers to the Afghans. At about the same time. a Pentagon group began recommending Sting ers. But the CIA remained skeptical. At a White House meeting late in 1985, Bert Dunn, then the chief of the CIA's Near Bas operations division, said the Pakistanis opposed equipping the mujahedeen with Stingers.

The stalemate over sending Stingers to Afghanistan finally broke in January 1986. when another congressional delegation me Mr. Zia in Islamabad. The Pakistani leader said he had asked for Stingers and was turned down by the CIA. "Zia couldn't have been more clear that this was the one weapon the mujahedeen needed or they would be butchered," Rep. James Courter. a Republican recalls.

\section{Limited Number}

The Planning Coordination Group met gain in Afghanistan in late February, and this time the ClA's Mr. Dunn. who earlier had claimed the Pakistanis opposed Sting ers for the Afghans, said the CIA had "no objection" to providing them. sources who were present say.

The Joint Chiefs recommended to President Ronald Reagan that the Afghans get limited number of Stingers. officials say, and in April Mr. Reagan directed the CIA to supply the missiles. The administration notified Congress of its decision.

But even the president's order wasn't enough to overcome the resistance from the CIA, which in May bought 50 Stingers from the Army but shipped them only as far as a secret warehouse in Virginia. Sixty days later, when White House officials asked where the missiles were, the CIA replied that they hadn't been shipped because they needed to be tested against a new defense that had appeared on a Soviet helicopter shot down in Angola.

The first Stingers finally arrived in the mujahedeen camps at the end of the sum. mer of 1986. For their own political reasons, the Pakistanis insisted the first of the prized weapons be delivered to a rabidly antiAmerican group commanded by a pro Iranian Islamic fundamentalist named Gulbuddin Hekmatyar. Pro-Western resistance oroups began to receive their allotments of Stingers a couple of months later.

The new weapons lived up to their adrance billing. On Sept. 26, rebel forces downed three Hind helicopter gunships near Jalamabad. Within six months, senior U.S. officials say, the Stingers had a major effect on the war, improving the morale of the rebel forces and neutralizing the Soviets' air power.

mong other things. U.S. officials say, the mujahedeen began using the Stinger as an offensive weapon, a tactic that hadn't occurred to the Army. On one occasion. intelligence sources say, a rebel band took its Stingers to the Soviet air base at Qandahar, set up shop not far from the end of the runway, blasted a few Soviet planes as they tried to take off laden with fuel and ammunition, then meited into the hills. Ineffective Tactics

The Soviets have tried to defeat the Stingers by dropping parachute flares and by flying at higher altitudes. Neither tactic has proved effective. Last February, a congressional delegation observed that Soviet aircraft were flying so high they sometimes bombed their own troops.

The weapon has been effective enough U.S. officials still worry about its falling into the wrong hands. The CIA demands that rebels account for every missile fired and compare these counts with its own intelligence before issuing new missiles. If the war ends, officials fear that the mujahedeen might sell the highly prized weapons to Iran.

$$
\text { AITSJ 2/22 }
$$




\section{Zia looks beyond Geneva}

by a correspondent in Islamabad

General Zia-ul Haque and his handpicked civilian government has recovered from the initial shock following Gorbachev's February announcement that he is prepared to withdraw Soviet forces from Afghanistan within 10 months (now reduced to 9), if the Pakistani and Kabu regimes sign the Geneva accord. guaranteed by the US and his government, by March 15 . In the bargain he has secured validity for his civilian government from the opposition and endorsement of his policies which is had consistently withheld. Nineteen opposition parties were called to two-day conference in Islamabad by prime minister Muhammad Khan Junejo on March $S$ for consultation about the Afghan issue.

The Soviet invasion of Afghanistan in December 1979 made Pakistan frontline State in the US strategy against the Soviet Union, and also brought a flood of refugees to Pakistan which over the years reached the 3.5 million mark. General Zia. capitalizing on these developments, agreed to play the US game of turning Afghanistan into a Soviet 'Vietnam'. As a result, massive US aid followed giving a new lease on life to the general who, until then was despised in the west. US aid to Islamabad opened avenues of even better life for the officers of the Pakistan army. In $\mathrm{Zia}$, they found the greatest defender of their interests, on whom the Soviet invasion was a godsend.

As refugees poured from Afghanistan, humanitarian aid flowed to Pakistan, enriching the bureaucrats as aid to refuges was channelled through the regime's machinery.

The Afghan jihad that began before the Soviet invasion also became reievant to the US's policy of letting the Russians bleed. The Saudis and Guif Shaikhdoms moved in with their millions to play their part in this crusade; and the number of mujahideen groups fighting the marxist regime in Kabul multiplied. With their eyes on the future each donor propped up its own group, but all used the cover of Islam to legitimize their divisive and subversive role in the struggie. The US aid for the 'jihad peaked to about a billion dollars a year; this and much of the other aid 100 passed through the Pakistani authorities before reaching the mujahideen.

Despite all the aid and interference the ordinary mujahid fought for his honour and for the glory of Islam. As the struggle raised the Soviet cost of occupation and it became apparent hat the continuation of direct occupation would eventually lead to the creation of a singie powerful Islamic movement and an Islamic State. the rules of the game changed. The US was no more interested in bleeding the Soviets 'to the last Afghan'. No one wanted another Islamic State in the worid to destabilize the bi-polar worid.

At the superpowers summit in Washington last December. Gurba. chev pointedly asked whether Wushington really wanted 10 sce the emergence of a government of mullahs Tehran-style in Kabul with all its repercussions on neighbouring Pakietan and eleawhere. The speed with which the US has moved to bail out the Soviets without having to suffer the humiliation of defeat, points to the convergence of superpower nterests. The aim is to deny the fruits of the struggle to the genuine mujahideen. Further rewards to the Zia regime depend on how neatly they play their act in the drama.

The Soviet occupation has devastated Afghanistan, made five of the 18 million people refugees, killed another 1.2 million and left four times as many injured and maimed. Today, no western government or media is raising the question of war reparations or putting the Soviet leaders on war trials for their crimes against humanity. Had the victims been Armenians or Jews. the siruation certainly would have been different.

There is no talk of dismantling Soviet hases either: no calls for the withJrawal of Sovict 'advisors' or their tockpiles of arms being left behind for the benefit of their allies in Kabul; or the return of tens of thousands of Afghan children taken to Moscow for indoctrination. In its zeal to bail the Soviets out, the UN Human Rights Commission has even discovered, early this month, that the human rights situation has improved under General Najibullah; only a few weeks ago he was supposed to be killing his opponents in cold blood.

The Zia-Junejo regime is concerned about the fate of US aid when Pakistan will no more be a frontline State. The $\$ 4.02$ billion US aid package, suspended last year for allegedly re-starting its muclear programme, was restored only just before the Washington summit last December to assure its host ${ }^{2}$ that the US means business. And only recently did the US assure Zia that it does not wish to end aid to the mujahideen until the final phases of the Soviet roop withdrawal.

No less is the concern about the future government in Kabul. The past regimes had laid claim to parts of Pakistan. Therefore, either a border demarcation between Pakistan and Afghanistan to be made part of the Geneva deal or the installation of a friendly regime in Kabul is what Islamabad is keen on. Further, it wants a settlement that would ensure the return of the 3.5 million refugees to Afghanistan.

An Islamic State in Kabul is not General Zia's priority. Indeed, he is reacting to US policy needs to preven such a development taking shape. If that happens, it will not only be a betrayal of the Afghan Muslims but also of the Muslims in Central Asia who have been inspired by the jihad in Afghanistan.

The major worry is how the mujahideen will react when the Geneva accord is signed. So far they have said that they will not accept any agreement which excludes their participat. on and curtails their ability to use Pakistan as an operational base.

Gulbadeen Hikmatyar, leader of
Hizb-e Islami, has gone as far as to say that his group will continue its struggle until the marxist regime is removed, and will move their headquarters either to Iran or inside Afghanistan if Pakistan gives in to Soviet pressure.

But General Zia does not think that this view is either generally shared or it is the last word from the mujahideen. (Ominously, the first rumbling of disagreement among the mujahideen alliance - which the west is keen to exploit - has come from Professor
Sibghatullah Mojaddadi who has made public his disapproval of the 'fundamentalist' tiit.) Pakistan is placing its faith in the US and the Soviet Union 10 impress upon the mujahideen that an interim government is the best inducement for refugees to return home. So far Washington and Moscow have refused to accept this argument totally. Both want to be sure that in the process 'fundamentalists' will be eliminated.
iRESCENT INT'L

$3 / 16-31 / 88$

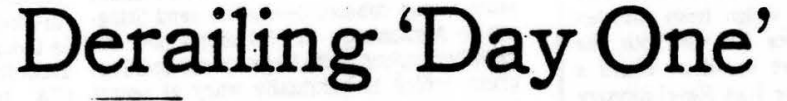

William Safire

4 ere is how our state Depart. ment's secret agreement to sell ment's secret agreement to sell ers was stopped by the light and heat of pitlless publicity.

Late in 1985, as the Rearan Administracion's foreign policy. makers were wading into the morass of supersecret mistakes, three State Department functionaries cooked up a pian to accoinmodate Soviet de mands about withdrawal from Afghanistan. The key concession: permit the Russians to continue arms shipments to its puppet Government while the U.S. cut off aid to the Mujahedeen (affectionately known in Washington as "the Moodge").

A letter to the U.N. mediator was prepared by Robert Peck, Amold

\section{Preventing: a secret sellout of Afghans.}

Raphel and Charles Dunbar for the signature of our U.N. delegate, Vernon Walters, to whom diplomacy is no fun unless it is covert

The secret letter assured Moscow that upon the day its troop withdrawal began, "foreign interference" would stop - meaning that the C.IA.-channeled aid to the Moodge, now more than a half-billion doliars in weaponry each year, would be terminated.

That Walters letter (with an escape hatch reading "if all the elements of the accord are satisfactory") commits the U.S. to be a guarantor of the agreement between the warring parties. It is known to insiders as "the Day One deal": American aid to the Aíghan resistance, but not Soviet aid to the puppet Kabul regime, would stop on Day One of the yeariong Soviet troop puilout. (Diplomats like o call such a lopsided agreement "asymmetrical.")

Who knew about this asymmetrical Day One deal? The U.N. knew, and the Russians along with their Kabul puppets. But the hard-fighting Moodge didn't know; the United States Congress was not informed of the secret deal; it may be that not even the White House knew.

State officials claim privately that Bud McFariane's deputy at the National Security Council, Don Fortier, had been filled in, but he's dead now.

" $m$ puzzled by that," Mr. McFarlane tells me. "The cutoff agreement was a fundamental change in policy,

but Don never raised it with me. I would have thought that George Shults, who I saw several times a week, would have brought it to my attention. That something of this impor. tance was proposed without the Chies Executive knowing is - well, puz. zling."

Doesn't puzzle me; 1985 was the year of one Reagan hand not knowing what the other was doing. But in early 1988, the Russians in Geneva started to hold us to the understanding in the Walters letter, and the odor from this Day One dead fish began to rise.

The conservative $4 \mathrm{H}$ club - Senators Humphrey, Heche, Hatch and Heims - began in February to denounce the "indecent" sellout scheme and to demand answers on what secret commitments had been given to Moscow on Afghanistan, the majority lead- 


\section{Canada's Best Article on Afghanistan, $19 \overline{8}$}

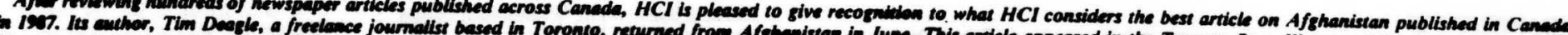
Hored, and (London, UK) Dailly Telozeraph.

Dy Tim Deagle

01987

YATTABAD, Afghanistan - By the time anyone hears the planes it is too late. Within seconds the bombs have almost completely destroyed the village, killing almost half the population and leaving many wounded.

Where the villagers sat just a few seconds before, there are now only grossly disfigured bodies among the scattered food and broken cups and plates. Some still cling to pieces of freshly cut bread. Injured goats and mules sprawl on their sides kicking, trying to stand.

As the two Soviet MiG jets scream low over the ruined buildings and fields, disappearing along the valley, the survivors of the small village of Yattabad in the Nangarhar province of Afghanistan are left with a choice: stay, without shelter or crops, or journey across the mountains to the refugee camps in Pakistan.

After the 34 bodies have been buried and the wounded tended, the men gather to discuss the situation.

The women and children sit outside in the snow waiting for their decision. I sit with them - as an "unbeliever," a non-Moslem, I am barred from the meeting.

The only outsider in the house is a man called Noor Ali Khan. Since he deserted the Afghan army in 1982, he has made 25 trips back into his homeland from Pakistan, not to fight, but to act as a guide to the constant stream of refugees fleeing the war.

In five years he has helped hundreds of men. women and children avoid the army patrois and cross the mountains into Pakistan.

When he was still in the army, Noor Ali Khan lost 11 members of his family, including his parents, his wife and his three children.

His reason for helping is simple: "I come here to help other families as I could not help my own. You see, these people here are my father, my mother, my brothers and my children. There are enough people fighting the Russians, but there are not enough helping our people."

After three hours of angry talks, the men come outside and tell us they have decided to leave for Pakistan. Noor Ali Khan will take them. It has obviously been a difficult de cision.

One village elder expresses the feelings of many. "Why did they do this to us?" he wonders. "We have never harmed them. My family has lived here for generations. We would stay, but look at our homes. There is nothing left, we must go."

The next morning before dawn, 41 survivors set out from the village. Thick snow already covers the ground and the air is frigid. The children and injured began to fall behind.

Most of the livestock have been killed in the air attack, and the group has only one mule. It carries the three most serious casualties, leaving the rest to walk.

By the end of the fourth day, six of the old and injured have died. They are buried hastily in the snow before the group moves slowly on, heads down, trudging forward hour after hour.

Meals are scarce and usually uncooked, and as the water runs out everyone begins to eat snow. May grow weak, and most of the children cough badly.

On the morning of the sixth day, as we approach the mountains, the snow gets deeper and the temperature falls further. During the night two of the children die, and now all the younger ones have to be carried.

I have 5-year-old Mohammed on my shoulders. He rests his chin on the top of 'my head and wraps his arms around my neck, keepin my ears warm. As we walk, he stares straight ahead at the mountains, repeating over and over again the word Inshallah" - "God willing."

Meeshka, 7, clings to my hand constantly. Her parents have been killed in the attack, and I am the only adult in the world she trusts. She keeps up a constant barrage of questions in a language I can't understand. I reply in a language she can't understand, but she seems happy with my answers.

The adults are not so easily reassured, and every night they sit around arguing about the decision to leave their homes.

I ask Noor Ali Khan if we will get them all to Pakistan. "Not all of them," he says. "Some will not make it over the passes where it gets even colder. But I worry about the smal ones; it is so cold. I do not know what will happen to them. We must pray to our God.'

Many refugees who make it this far ar caught and sent back, others are attacked by helicopter gunships.

The pass that Noor Ali Khan has chosen is a narrow valley about 10 kilometres long, with the mountain walls towering above it on either side. Once inside, there are few places to hide and fewer exits. It is the most dangerous terrain to be spotted in, and also the most likely. We travel at night, the darkness at least protecting us from the army patrols and helicopters

By the end of eight hours walking on the first night, we have covered only seven kilometres of the valley. We walk in single file, following the next person's back never more than six paces ahead, the only thing visible.

Sometimes, muffled conversation drifts back along the line, and although unintelligible, it is reassuring.

On the morning of the second day in the valley, two of the group are missing - an elder ly couple who have found the walking difficult from the start. We search for most of the day but never find them. re inside Pakistan.

Many of the group immediately fall to the ground and pray. Some cry and a few turn around and silently stare back at the mounains. Thinking one man has not understood the message, Noor Ali asks him if he knows where we are.

The man remains staring at the mountains and quietly says: "I know we are in Pakistan, but will we ever see Afghanistan again?"

The survivors from Yattabad now live in ramshackle formation of tents made from scraps of cloth. These offer little or no protection from the elements, and subsequently many of the children have died from pneumonia. Mohammed and Meeshka, my two char ges, both died three weeks after reachin

The camp is set on a dry river bed 30 kilometres outside Peshawar, on stones and rock where nothing will grow. The refugees fear that when the rains come later in the year, erything will be washed away.

They have no aid from the Pakistani government, although they have been registered, and as farmers they cannot find work. Some feel they would be better off in heir old village.

Of the 75 original inhabitants of Yattabad, only $\mathbf{2 0}$ are alive today. The conditions they live in are harsh and unyielding. Disease is rife and spirits are low. They have lost their home and their families, and now many have lost

But Noor Ali Khan has not lost hope, and has gone back across the mountains. I will keep going back to help these people leave their country," he says, "but une day, I do not know when, I will take them home.

HCI Netis

Pakistan's Zia

\section{Sees Turmoil For Afghanistan} By Fradercx Keaps

Staff Reporter of Twe WaLL STaret JounNAL ISLAMABAD, Pakistan-President Mohammed Zia-ul-Haq deflated some of the euphoria over yesterday's signing of the Afghanistan accord in Geneva. predicting "trouble and turmoil" ahead. He pledged to continue backing the Afghan resistance in its efforts to topple the Moscow-backed Kabul regime despite the likelihood of Soviet-inspired retaliation against Pakistan.

Sounding defiant and confident in three-hour lunch session with reporters. the Pakistani president for the first time blamed sabo teurs for an ammu. nitien-dump explo sich in Isiamaba Sunday that left at east 93 dead an 1.100 injured. Many of the weapons lost in the explosion had recently arrived on U.S. transport planes and were inended to give a shot $n$ the arm to the re

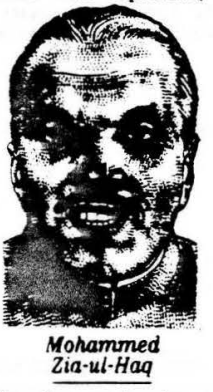
that although the first of 115.000 Sovie roops would start leaving Afghanistan on May 15. the test of wills over the future of Afghanistan would contunue.

His statement was the clearest signa yes that Pakistan. the critical conduit fo arms to the resistance. intends to remain major player despite a portion of the Ge neva accord that obliges it not to support directly or indirectly, rebeilious or seces sionist activities" in Afghanistan.

\section{Costradictory Agreements}

That portion contradicts a separate agreement between the U.S. and the Sovilet Union under which the two superpowers have the right to continue arming the war. ing Afghan parties. President Zia's statements are likely to heighten tensions between Moscow and Islamabad despite the signing of the accords.

Perhaps Pakistan will have to pay a little more price until the mujahedeen Moslem resistancel achieve their aims in Afghanistan." he said. "If worse comes to worse, then Pakistan will face the music and will pay the price," which he said woutd be "arm-twisting, border-bombing and other things."

Although President Zia didn't mention the Soviets or the Soviet-controlled Afghan government by name in connection with the Sunday explosion, be sajd it was " $m$ y own personal assessment that it couldn't be anything but a very effective act of sab otage." He declined to give details. pending a government inquiry, but said the sab oteurs wanted to embarrass the Pakistani
military and create tensions between it military and cree people.

dhe people.

President Zia was clearty buoyed by the Geneva signing, though he said it doesn' satisfy Pakistan's two remaining goals of repatriating three million Afghan refugees and bringing about a nonaligned, self-de ermining Afghanistan.

Terming the Soviet withdrawal from Af ghanistan a "miracle of the 20th century." he said. "I openily confess that I was one of those who said it was impossible." He said the fall of the Najibullah government in Kabul is inevitable and predicted the He shrugged off comments that Pakistan would need to volate the Geneva

agreement in order to back the resistance. "We are going by both what is in the ac. cords and what is not in the acconds." he said, smiling. He quoted U.S. Secretary of State George Shutz as saying it was up to the lawyers to find out how that could be done. In Geneva. Mr. Shultz pledged con tinued U.S. supplies to the Moslem guerrillas, but a U.S. statement added: "'Should the Soviet Union exercise restraint in providing military assistance to partles in Af ghanistan, the U.S. similarly will exercise restraint."

Mr. Zia made clear that Pakistan would allow the three million Afghan refugees to remain inside its borders until they decided of their own free will to go home.

"They [the resistancel haven't got much confidence in the accords and I can understand their point of view," he said. "I 


\section{To Avoid Losing the Peace, West Must Build Afghan Unity}

\section{By DANIEI, PIPES}

What are the Soviets up to in Afghanistan? Their willingness to withdraw forces can be interpreted two ways.

The optimists (which includes the Reagan Administration) believe that Mikhail S. Gorbachev must get out of the war in Afghanistan if he is to go forward with his ptans for perestroike. According to them the war is an inherited burden (a "bleeding wound") that must be cast off as quickly as possible.

The pessimists hold that Corbachev's tine words and fresh spirit must be seen in the light of a 70-year history of unrelenting Soviet military ambition and territoria expantion. They are wary. Not knowing Gorbachev's motives, they want the United Steitee to prepare for the worrs. They fear that the Soviets (oetendible moves to leare the country notwithstanding) still plan to coneolidale their control of Alghanintan Penimists suspect an application of that cinmic Rumian dialeetic-one atep beck. two stcps forwand.

The main reason, the pessimirts point out, to doubt that the Soviets really intend to withdraw in that they have too much to loee by leaving Afghanistan. Even though Sovies forces have not been able to pacify the entire country, they nevertheles enjoy significant benefits there. They control several principal cities and are feverishly exploiting Afghanistan's extensive mineral and gas reserves. In addition, they control forward airfielde that bring Soviet forces hundreds of miles cloeer to the Persian Guif and potential hegemony over the huge oil and gas reserves there. Control over these would give the Soviet Union major leverage over the world cconomy.

Abandoning Atghanistan would exact more than a material price; the psychological cost for the Soviet state would be immense. Moscow's place in the world, after all, depends on its being perceived as powerful-a defeat by rag-tag insurgents would badly erode its reputation. Also, there would be domestic consequences for Cbrbachev, as Soviet military leaders will surely not accept a defeat in war with srace.

For all these-reasons ${ }^{2}$ abandoning the country will cost the Spviets dearly. Why, then, do they agrce to withdraw their forces? Recent Soviet activities suggest that they are embarking on a new and more sophisticated strategy to achieve preciscly the same goals they have fought for since 1979. Withdrawal may provide the most realiscic and least costly means of doing this.

Moscow's problem lies in the worldwide agreement that the Red Army brutally and wrongly invaded Afghanistan. Afghans and Americans, as well as the Pakistani and Chinese leadership, all agree on this, as do many West Europeans and Muslims. There is no other issue in the world today that generates such wide anti-Soviet hostility. This consensus carries great weight: indeed, it is the single most important source of support for the Afghan moujahedeen, or resistance fighters. Without such massive backing, the moujahedeen would be a far weaker force.

From the Soviet point of view, the enemy's center of gravity lies in its far-reaching popularity. If Moscow can change public opinion, it can reduce the widespread opposition to Soviet troops in Afghanistan, undermine the pro-moujahedeen consensus and undercut the opponent. The battle for Afghanistan would effectively be over if Moecow could only mire the moujahedeen in the kind of controversy that faces the other forces fighting the Sovict bloc. In short, Moecow neads to turn the moxjahedern into Conres.

How to do this? An answer can be found in the steps actually taken by the Soviets in recent months. Very cleveriy, they have offered to undo what everyone objects 10-the presence of Soviet forces in Afghanistan-while preparing the way for a more nuanced role. They have created the conditiona for a scenario that will go something like this:

Moscow very rapidly withdraws its troops from Afghanistan, so that a majority of them are out by this summer (though. of course, military "advisers" and KGB agents will remain). This has two main consequences for the Soviets. First, they win good will internationally, erasing the years of obloquy that rhey have suffered. Indeed, there will undoubtedly be many observers who will seek to reward the Soviet authorities for taking this step. This will render future assistance to the moujahedeen very problematic.

Second, the withdrawal creates a power vacuum in Afghanistan that the pro-Sovict government in Kabul and the anti-Sovie moujahedeen scramblc to fill. Worse, the long-tensc relations among the seven resistance groups crupt into open discord and possibly into civil war. Anarchy follows, with murder and atrocities becoming common. Afghanistan comes to resemble Lebanon, lacking a central authority and torn by groups competing along ideologi cal, religious, geographical and tribal lines.

Anarchy would irreparably sully the high reputation that the moujahedeen have sustained through eight years of valor in war. Their true toughness, even barbarisin. will suddenty become apparent, leading to a quick dissolution of their wide backing.

Anarchy would also create an opening for Soviet forces to return. At the minimum. Moscow could fall back on "the protection of Soviet personnel" line to justify renewed military action in Afghanistan. At best, it could get a legitimate Afghan group to request its aid. Alternutely, the Soviets also seem to have prepared the way to split off the northern portion of Afghanistan and bring it under their direct control.

In any casc, the Soviets would return to a brutalized country where the locals had shown themselves incapable of self-government. Thesc conditions - so completely different from 1979-would win grudging acceptance internationally. If the choice is the Sovicts or carnage, most observern would choose a Soviet pax. This is, after all, what permits the Syrians to operate in Lebanon or the Vietnamese in Cambodia without serious international opposition. In thesc conditions, it would be only a matter of time before Afghanistan fell wholly under Soviet control.

The Soviets would then have achieved politically what they had failed to win militarily.

The United States has a tradition of winning the war and losing the peace. After both world wars, Americans washer their hands of conflict to get back to more pleasurable pursuits. In both cases, this quick loss of interest created terrible problems in subsequent decades. It is important to keep a close cye on Afghanistan to make sure that eight years of war are not in vain.

What can Washington do to preven losing the peace? Much hinges on mouja hedeen disunity. As long as therc was a joint enemy, disunity was manageable. But it could have a lethal effect once most of the Red Army evacuates and Afghans are left to govern their own country. If Afghanistan is to regain its independence, the moujahedeen must unify to form a single authority that can govern the country. Until that happens, the Sovict forces will continue to threaten

Therefore, the West should concentrate on helping to build Afghan unity. The composition and orientation of the government matters less than its ability to control Afghan territory. (The same applies to Iran: Bad as it is, the Khomeini government is far preferable to a breakdown of autherity and the threat of a Sovict invasion.)
Keeping this in mind, Washington should with others to eatabliah a porem ment in Kabul. Bftorts devoted to getting the seven monjatedeen groups to coopernte have so far bad little succes. And with the taste of power in their mouths, the Peaha. war leaders are lese likely than ever to work together.

New thinking is needéd here. One idea is to pick juat one moujaredeen build up its power and authority. This group alone would then receive all the outside world's finaneial aid and diplomatic backing. If arms continue to be supplied, it alone gets them. With luck and dexterity, concentrating resources in this fashion would lead to the emcrgence of a single authority capable of maintaining order in Afghanistan.

We have now entered the critical months of the war. The Geneva accord is important but it must not blind us to the complexities that follow. If the U.S. government does not act with care and imagination, 1 million deaths and the sufferings of 5 million refugees will have

Daniel Pipes is director of the Foreign Policy Research Institute in Philadelphia. He recently returned from Geneva, where ho covered Afghan affairs as a U.S. delegate ta the United Nations Commission on Human Rights.

\section{4/4 Ios Angeles Bimes}

\section{ON MY MIND Saigon and Kabul}

a the 1970 's, when the United States was tacing military disaster in Vletnam, the Soviet Union stepped in to help the Americans save (ace and salvage as much political capital as possible.

Firsh, Moscow worked out an international agreement permitting American troops to withdraw over as many months as Washington thought necesthe Kremlin agreed that the South Vietnamese Government, the battered American ally, could remain in power in a strongly fortified Saigon, with full intermational recognition.

In its desire to help Washingtion. Moscow also agreed that the AmerMoscow also agreed that the Amernamese regime continued economrc aid. Thousands of American-traine C.I.A. agents remained in the country after the troop withdrawal.

And the Soviet Union informed the Vietcong that no more Soviet military aid woutd be sem, uniess the Americans added someday to the huge stockpile the U.S. was leaving Saigon.

Naturally, the Vietcong did not like all this and feit it deserved to take over power in Salgon, as the reward for de leating the United States and the South viecnamese. Bul Moscow, eager with Washington on ocher matters, overrode the Vietcong entirely. The only comfort it

gave its allies was to assure them that one day the Vletcong wouid indeed in-

A fantasy, bue someching like it is being played out in Alghanistan, very real life. The Russians, faced with military defeat, have wisely agreed to pull out. They are doing it preity much on their own terms, designed to keep the Afghan Communists in Kabul in been for naught. sary, without any verification. Then umph, so go to it and good luck.

The Kaber Governmen will probably be deteated one day. Bur before that day a be more Afehan blood will have to be spilled to ave the resist 政 ermment.

Americans do not seem to care great deal the major reason probably is that the withdrawal of Soviet forces 
Hunger may greet Afghans on return to shattered land

\section{An S Kent \\ if FAiNWAR - International nll- oncials are warning that t eurnat wrangle over a Soviet -ithdrawal from Aghanistan couid see the welfare of the people at the heart of the crisis - 5 mil- lion refugees in Pakistan and Iran - lost in the shufning of diplo-} matic paper.

If and when peace is achieved. diposessed families will return a devastated countryside incapable of feeding them.

But, even while one branch of the United Nations presses for a peedy exit of Soviet troops at pasce talks in Switzerland, anothgioner For Refugees has been in the words of one respected aid worker, "asieep at the wheel."

"Only now is the LNHCR wak. ing up to the fact that this will be the largest single repatriation of refugees in its history," says Anders Fange, chief of the Swedish Committee for Afghan Refu. grees.

\section{Destroyed lands}

"They're caught totally unpre pared - there's absolutely no pian in place to prevent chaos"

The Swredes are one of the many mivate voluntary agencies at ready operating small health. ducation and emergency aid prorams inside Afghanistan from offices on Pakistan's northwest frontier.

But the U.N. commission's strict mandate has prevented their own relief effort from reachins acrose the border into the war zose It's a handicap, say spokes. mea for the voluntary agencies which will cripple the commis sion's effort to cope with the Af ghans' return.

"They know the refugee camps, that's all," says Fange. "But inside Afghanistan, there's a crisis of de stroyed lands, of depleted live stock, of political disputes that will threaten everything you do to try to rebuild the country. What they're beginning to realize is that the toughest. most dangerous work has just begun."

The refusal of U.N. officials on the northwest frontier to comment in any way on the matter an indication of the procedura straitjacket in which they find themselves. While insisting that initial planning is under way, one commission worker - who re quested that be remain anony mous - admits: "Any UNHCR program to assist civilians inside the country would be subject to prior arrangement between the organization and the governmen of Afghanistan

Your guess as to what that government will be and when it' be in place is as good as mine."

What everyone connected to the current relief effort fears is mass migration into famine, tragedy that could well exceed the estimated 1 million civilian war dead. Although some discount warnings of a disaster on a par with Ethiopia, many observer feel there's a real risk of an even greater catastrophe.
By 1 ses durte the word of the aerial bombias that he been th cy instrupen of the Sovist side of guerrilla sancturies, 12 . 000 of Afghanistan's 22,000 farm villages had been destroyed of abandoned, with anothes 5,000 left critically damaged.

The Agricultural Survey of Afghanistan, which sent monitor across the country to document the damage, says in a recent re port that Soviet restrictions of commodities vital for food production - seed, fertilizer, fue and tools - has caused a spiral of agricultural decline that has left fields barren. They will need

But as they wrangle on in splen dor by the shores of Switzerland' Lake Geneva, it is doubtful that the legion of negotiators at the U.N.-sponsored Afghanistan peace talks are much interested in the reproductive idiosyncracies of oxen, in the breaking of soil left untended under a scorching Asian sun, or in the rebuilding of underground irrigation channels blown apart by bombs.

Yet, mundane as they might seem during a charged debate bout peace accords, weapons shipments and armies on the march, these are the factors that will decide the fate of what has become the world's single largest clutch of refugees.

"The animals needed to pull the plowshares, the oxen, have been depleted by 50 per cent in the war," says Dr. Azam Gul, prominent Afghan agriculturalist and himself a refugee of the December, 1979 Soviet interven tion.

\section{Poitical outlook}

"Under normal conditions, it would take five to six years to regenerate that population remember the calves can't repro duce for three full years."

Compounding this drag on culivation will be the more immediate challenge of irrigation, partic larly in the many harsh dryland arming areas of the country. It was the destruction of their intricate, centuries-ald kerias, or underground waterworks, that was the final blow to many $A f$ ghan farm families reluctant to embark on the long trail of tears leading to the camps.

Add to these adversities the ex pected eight to nine years needed o regenerate the herds of sheep goats and cattle - the livestoc essential to supporting a nation 85 per cent dependent on subsistenc agriculture - and the Afghans passage home looks like a poten ial ticket to oblivion.

Consider the political outlook and the picture looks even worse.

"Just how many of these over. grown boys with their guns, these mujahideen. . . will be willing to trade in their precious Kalashnikovs (rifles) for a plowshare?" asks one experienced field work

Much more serious, say spokesmen for Afghanaid, a British re lief unit based in Peshawar, is the threat posed by .loscow's insistence upon maintaining upport of the Communist regime in Kabul years of back-breaking wor

ter a Soviet withdrawal - a arms and ammunition to both sides in the warring countryside.

"Even if all-out civil war can be avoided, how can civilian farm families be expected to pick up what's left of their lives in what amounts,

For their part, the private aid agencies have launched an urgen study which will likely advocate an entirely new relief systen guided by their own veterans of the wartime countryside. Th reveal its plans, but word on the frontier is that the agency's officials are doing much the sam things these days as the refugees in the camps.

They are praying for deliver. ance.

Arthur Kent is a freelance jurnalist based in Asia.

TORONTO
THE SUNDAY STAR, MARCH $2 \mathrm{R} 1998$

\section{End Game:}

Soviet bombs are also reported to litter ine countryside.

\section{Dy HENRY KAMM}

But even if the return to Afghanistan ia a carefuily staged, phased movement, officiats and reiugee workers say they will nave \& probicm providing for a sival mass of uptooted people coming rome to a devastated country. Underdeveloped as Afghanistan was before the Soviet troops arrived, it stil provicieu a minimal infiastructure to pourish, house and transpor a populaBut current'intelligence reports, wnicn officials say are corroburated by the accounts of travelers frum Aignanistan, describe a country of scorched

Among the problems associated witn the refugees' return are these:

qhow to make the return coincide with the food-growing season. Wheat Afghanistan's principal food grain. vesting in May. provide the escentials to consider shouldering the huge cost of raise such a crop. This begins with the emoval of the mines that the opposing Jrces have sown in generous quanti-
9How to prepare for replantins fiejds that have lain fallow for years. Drant animals and tools have been destroyed. The soil has become hardened by lack

OHow to insure a sufficient suppty of seed, fertilizer and pesticides and dis. tribute it over a heavily damaged network of roads speckled with mines.

IHow to provide food $t 0$ tide the retur zees over until they can provide for

qHow to repair an ancient system of rigation canals that has been largely uescroyed or made unusable by lack of naintenance.

Thow to provide minimal housine. Many villages have been razed to deny been destroyed in battle, and still thers have collapsed from diquse. While mud huts will not be too difficult o rebuild wood for root beams is carce.

The United States, Japan and West consider shouldering the huge cost of noving and resettling the refugees and restoring the infrastructure necessary

THE NEW YORK TIMES

MARCH 29, 1988 of use, requiring metal plows and

\section{Afghans living in hope that talks} will end the exile

PESHAWAR: "If the Russians leave I'U go home."

The speaker was Imam Jan, one of three million Afghan refugees in Pakistan keenly following United $\mathrm{Na}$ tions talks on ending the nine-year war that drove him out of his country.

Most of us feel that way," he said and a line of grey beards behind him nodded in agreement.

The men, gathered in one of the scores of mud-buil 
Isolated Afghan Refugee Camp Life
Turns Women Into 'Birds in a Cage'

DY HENRY KAMM

ISLAMABAD. Pakts. an, March 25 "WLAMABAD. Pakts. An, March $25-$
"We never ask ... wo women," Sultan Mo hammad said indignantly. ghan farmer and a refugee in the Tha was restrained from showing greater anger only by the tradition of hospitality under the roof of his hut. He had been asked whether the men woukd consult their wives before taking the vital decision

Sadia Ansari, a young teacher, was asked what had changed in the lives of women since they went into exile. "This," she said, pointing to the veil she wore over her head. "Purdah." She was referring to the custom of Mosiem traditionalists of cloistering women from the view of outsiders by making them stay indoors and wear a veil in company.

Fundameatalists Dominate

The customs of Mr. Mohammad, the farmer, have been imposed on the educated women of Kabul like Miss Ansar in their exile in Peshawar and the refugee camps. Moreover, the dominance of Islamic fundamentalists in the war against the Soviet-backed Alghan Gov. ernment and among the three million relugees in Pakistan has made the life of the village women even more restricted than it was at home.

"The women are the main victims od the war," a refugee official said.

Even belore the extablichmeat of a cia Even the men who impose the re deprived lives of women as refugees. "The womea are like birda in a cage," - guerrilla commander who gave his name only as Mohammad in the Lalthd have only their houseworts and noth

"The women are confined," said an anchropologist worting for an interna. tional organization. "They used to do most of the routine agricultural labor. They got out of their houses because village life was much more homogen. village life was much more homogenous. Now they have no work and no reason to leave the house, while there is a hich likelinood of being.

\section{Beredoen and Melanebolla}

Refugee men, as well as Pakiatad and foreign refugee workers, conclice boredom and meiancholie the woman's lot in all of the mud hut campe that line the border. For the two Afghan women interviewed, it was the gravest problem of refugee life.

"Camp life is so sad," Miss Ansar said. "They cry from morning to night. In A/ghanistan, the wives' life was ver happy. They worked; they brough

(eacher spoke of the sadness of the Alghan women, the
Mr. Mohammad, a 43-year-old AIcamp south of Peshawar for five years. cial captal of the Afghans in exile. strictions speak with sympathy of the Banda camp south of Peshawar. "They else to do. They are not happy. more agitated she became and the less she cared that the black veil that she wore over her head without covering her face slipped off completely. An edur cated middle-class woman from the capital, she finds even limited purdah a new experience.

"At home, sometimes I wore a little scarf," Miss Ansari said, scoffing at the bigger shawl of black cotton that is her concession to the prevalent traditionalism.

\section{Afghan Holy War}

ISLAMABAD: Several hun- their country," a reliable source dred nationals of Arab states said in Peshawar. have joined the Mosiem Mujahedeen in their Jihad or Holy War against Soviet troops defending the Kabul regime, number of sources have said.

Most of these Mosiem fighters. who have come from Egypt, Saudi Arabia, the Sudan. Kuwait. Jordan, Syria. Tunisia, Moroceo and $\mathrm{Palestine,} \mathrm{are} \mathrm{aged}$ between 20 and 30 , and more than half of them have links with extremist Islamic organisations. diplomats and specialists on Arab affairs said.

The embassies of moderate Arab countries are keeping an eye on their nationals, especially those suspected of beionging to extremist movements.

An Arab diplomat said that an eventual resolution of the Afghan conflict would likely see these hardened fighters return to their countries of origin.

They usually stay with Mujahedeen groups in Afghanistan or Peshawar in northwestern Pakistan for an average of two years, undergoing intensive military training in guerilla warfare at Afghan resistance camps.

Almost all the Jihad candidates join radical parties such 23 the Islamic fundamentalist Hezb-i-Islami led by Gulbodin Hekmatyar or the Ittehad-eIslami headed by Abdulrab Rasul Sayyaf or factions of the Wahabi sect - radical Saudibacted Mosiem - in nurtherm Afghanistan, sources said.

Some ideatiats leave one fine ay to wage Jihad against the comanist Kafirs (non. wevers) for personal reasons bore than half are sent by expmist Mosiem groups in vidually want to do something for Islam in pursuit of their Koranic studies," the source added.

Today Mosiems are fighting oly wars against the Israelis and the Soviet and Afghan troops in Afghanistan, a young Algerian said in Peshawar recently.

The Arab Jihad is fought discreetly, wathout coverage in the Pakistani press or through rebel leaders.

Meanwhile, Pakistan's Deputy Foreign Minister Zain Noorani flew to China yesterday for further consultations with allies before thenext round of indirect talks with Afghanistan.

Mr Noorani returned on Saturday trom talks in Washington and London on Afghan peace prospects with US Secretary of State' George Shultz and Britain's Foreign Minister Sir Geoffrey Howe.

Foreign Ministry Secretary Abdul Sattar is currently holding taiks in Iran, another major backer of the anti-communist Afghan guerillas.

Pakistan is due to resume indirect calks with the Kabul governmeat in Geneva on March 2 on a withdrawal of Soviet troop and a hait to aid for Afghan re. bels based in Patistan.

Mr Noorani's travels follow the offer two weeks ago by Soviet leader Mikhail Gorbachev to pull out troops by March 1989 if Pakistan signs an accord by March this year. Pakistan says a new broad-based government must take over in Kabul before it signe an apre ment.
"Often those who arrive indi-

The Rearan Administration urged the United Nations to organ ize a multinational drive to help about 5 million Afghan refugees return home after Soviet troops withdraw from Afghanistan. The United States is prepared to heip. but the United Nations and its agencies "are the logical organizations to coordinate the job." State $O$ Department spokesman Charles Redman said. Adding to the difficulty of repatriating the refugees is the likelihood of continued fighting between warring Afghan factions after the departure of Sovie: troops, scheduled to begin May 15.

"At home, when men came to visit, I sayed in the room," she said. "Here have lo go away.

"We had more liberty in Afchanistan," said Mrs. Kakar, the priacipal, who comes from Konduz, near the wamed, even at night."

Desplte the men's realization of the special difficulties of women's lives, tradtion is so strons that it exchudes the possiblility of lifting the isolation that makes their exile life more miver able than that of men.

"We won't permit the women 10 es curalde, even if we bae our lives," said Mr. Mohammad in the Thal cana "The only people they can meet are tre women of our tribe. It's out religion."

Scholars believe that the tribal cus coms of the Pachans, who live on both sides of the Pakistani-Afghan border. impose much greater isobation on women that Isiam requires.

"Most of the women want psychotherapy for depression," said Dr. She hide Qazi, a Pakietani and Pathan who works at a woman's clinic run by the French International Action Aeainst
Hunger for the United Nations high commissioner for refugees. "They are sad and worried. I tell them the Afghan problem will be settled and they can 80 home. I just comfort them. In bed

As in health, in education as well ine international aid organizations come up against the resistance of Afohan men. The camp schools run by relief agencies under the auspices of the United Nations High Commissioner are in the great majority for boys. There are 486 primary schools for boys and 76 for giris, 161 middle schools for boys and 2 for girls, and 4 secondary Tchois, all for boys.

Total enroliment in the United $\mathrm{Na}$ ions schools stands at 104,600 boys and 7,800 girls.

Boys go 10 school for as lons as poed ble, said Mohammad Muthit, a 34-yea Surincipal of a primary schoed school at age 10 or 11 .

"Then they 80 to weave carpets Mr. Mukhi said.

What if a girl is particularly intel gent? "Whatever her intelligence, at f or 11 she has to go to weave carpets he replied. "All the men think sa."

become doctors," Mr. Mukhi said, "by

\section{per Vechernyaya Mookva
reported Thuraday.}

\section{Soviets Will See Afghan War Movie \\ Prom Reuters}

MOSCOW-The first So viet feature film about Afghaniatan will be shown in Soviet cinemas shortly, the Moscow evening newspa

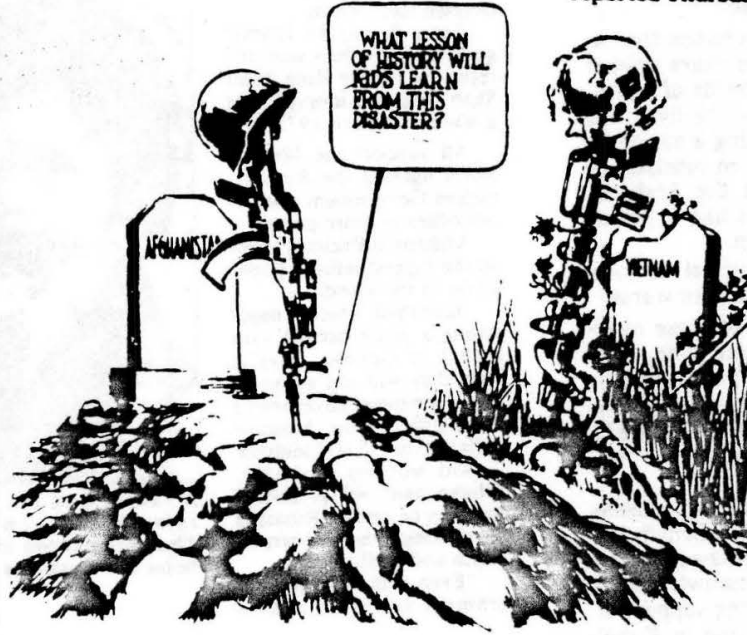

\section{.} to hisor, remaining true to his soldier's oath to his
mocherland," is eaid. $v i$ "- the nickname given to Soviet troops in Afghanistan-is about a young Soviet soldier who was cap- 
Many readers are familiar with the problems of educating Afghan refugee children in Pakistan; fewer know about the situation in Iran. Until quite recently there were no educational opportunities offered to Afghan children in the Islamic Republic nor for the first several years after the Soviet invasion were Afghans accorded refugee status. In February 1980, this writer was rebuffed by the then Deputy Minister of Defense \& the Director of the Pasdaran Inqilab, Hojatolislam Ali Khamenei (the current President of the Islamic Republic) when I suggested that Afghans be recognized as refugees by the Iranian authorities and that schools be created for Afghan children. In the absence of "refugee" recognition in Iran, the Afghans were deprived of any international help and were barred from any sort of formal education. As "illegal aliens" Afghans in Iran also fell outside the programs of the regular Iranian charitable organizations, such as the Red Crescent. As illegal aliens, the Afghans could not establish any educational - or other - organizations. Afghans could not buy houses. Even now, properties have to be registered in the name of an Iranian citizen for the Afghans. Afghans could not carry on regular trading, such as hawking wares in the bazaars, without harassment by the police. often, Afghan goods were taken by the police and never returned.

According to Hojatolislam Khamenei; there were more than 30,000 Afghans in Iran in 1979. Most settled in the provinces of Khurasan and Zabul. A few even moved to the western part of Iran but were turned back by the Kurdish communists. Many eventually settled in Shiraz, Isfahan and Tehran as well as places in between. None of these places had schools of any kind for the Afghan refugees. Immediately after the Soviet invasion, tens of thousands of refugees poured into Iran from places as far as Parwan and Maimana. Afghan and Iranian educators (mostly retired teachers and Khurasani relatives of the Herati refugees) opened several "schools" for the Afghan children. However, the educational problems were overwhelming.

In a Letter to the Educators dated 5/6/80, I wrote the following:

In a recent visit (February 1980) to Afghan refugee camps in Iran, I and several Afghan \& Iranian teachers established schools (essentially a room in a house) for the children of refugees. After establishing several of these schools we discovered that the children, after testing, did not retain as much of the material as the same age cohort did two years ago in Afghanistan (where I was on sabbatical doing field work). The refugees scored $20-30 \%$ lower that their counterparts. They also scored far below similar Iranian students. We discussed the reasons for this and identified the following as possible factors:

1) Children of the refugees are not the same as those with whom they are located \&, therefore, feel like strangers in a not-too-friendly environment.

2) Most of the children do not have parents; they either have been killed or are still fighting in Afghanistan.

3) They do not see much of a connection between their curricular materials (as meager as they were) \& their environment \& for cultural \& political reasons resist re-socialization \& acculturation to the Iranian way of life. 4) Teachers(both Iranian \& Afghan) do not know how to go about socializing these young Afghans who do not expect to settle permanently in Iran. Since no one is able to guarantee that they will eventually go home, something analogous to a total anomie seems to be taking place in the Afghan refugee community, especially among the school-age population. Students \& teachers exhibit behavior that would seem pathological under normal circumstances, but has become routine in the camp environment. This behavior ranges from naked aggression on the part of some students \& teachers to almost complete withdrawal and regression on the part of others. 
5) The refugees interpret moves by the Iranian authorities, ostensibly to ameliorate their pitiful lot, as devices to scatter them or "Iranicize" them. Therefore, they resist any form of overtures toward them by the host country. To the refugees, these moves by the Iranian Gov't mean the abandonment of their own culture \& tradition to some degree.

6) Many of these children are traumatized \& "shell shocked" as a result of seeing many of their relatives killed \& their villages destroyed by the Russian armed forces.

7) Some seem to be in need of psychiatric treatment \& all are in need of the basic necessities of life such as food \& shelter.

The"schools" were soon closed by the Iranian authorities. Some of the Shii Afghans were able to utilize Iranian charitable organizations like the Red Crescent. The children of these Afghans were also able to enroll in the regular Iranian schools. And, to my knowledge, there was no overt prohibition of the children of Sunni Afghans enrolling in the schools of the Islamic Republic. The Sunnis simply refused to enroll their kids in the Iranian schools. Some Iranians privately were able to help a handful of the Afghans who were sick \& wounded and some Afghans were able to create schools in secret for their children. I think the Iranian authorities ignored these schools rather than being unaware of their existence.

But the regular Iranian schools did not teach the elementary matters of the Sunni version of Islamic history, let alone anything about Afghanistan. This latter problem is similar to the one Afghan children confront in regular Pakistani schools. In these schools the Afghans apparently learn the Sunni version of Islamic events in Urdu (as the medium of instruction) \& learn nothing about Afghan tradition \& culture. The Islamic Republic, however, has been quite willing to send Iranian textbooks for distribution within Afghanistan. But these books, because of their Shii view on figh \& history have not received the seal of approval of most Afghan mujahideen.

It was not until 1986-87 that a few schools were opened in Iran for the Afghan children. Private communications \& meetings with Iranian Education Ministry officials have assured this writer that Iranian authorities are helping Afghan educators. Recent issues (Oct.-Nov. 1987) of the Inqilabi Islami Afghanistan (a Jamiat Islami Afghanistan publication from Tehran) herald the opening \& functioning of several schools (elementary \& secondary) for both Afghan boys \& girls in the Mashhad area. Let us hope that this trend continues \& the schools are permitted to receive some very vital financial \& educational help from the Islamic Republic, international organizations \& interested individuals.

M. Mobin Shorish

Univ. of Illinois - Champaign

\section{... and, on the other hand, Afghans}

$A^{S I F}$ the Guif war were nor headache A enuugh. Iran has crouble on irs eastern border tio. The reteilion in tighanistan has made it the retuctant host of up to ?: :m Atghans, who tirm the world's secund-largest horde of retugees atter the $31: m$ in Pakistan. The uffice of the $L=$ High Cummissioner for Retugees reckons that lran has done a remarkable wo with the Atghans, tew of whom have been put into camps. Voluntary agencies, and refugees who have lived in both countries, are less enthusiastic.

Only $5+.000$-efugees recerve what is called "care and maincenance" handaiut metions in reception and transit centres. kcording to the Commisstuner suffice. A report published in lanuars ty a group of British-based and anencies avs that the rest have to fend tor themselves, and that chev are reserncted in the surt of jobs ther can do and where ther can live. Most refugees stay in the border provinces of Sistan-Baluchistan and Khorasan, but Af- ghans can be tound all vier the counerv working in the cunstruction industry or picking truit in the orchards. In some Iranian cities whole netghbourhoods are Afghan.

The refugees gee to beciause most of them speak Farsi or dialects of ic. The Iranians give them ration cards like the local fopulation, so thev have access to heaviliv subsidised basic rood. Those who have not bothered to register are helped alung bo triends but have difficulitr getring work since labour inspection is tarly stringent. Iran has begun accepting officual heip for its retugees but does not allow internacional voluntary agencits to work there. The toughest conditions are in the new Arghan villages near the burder. peopled almost entreiv by women and thildren while the men look for work in the ciries. or tight at home.

Iran has given unstinting moral sup fort to the Atghan resistance. It insists on the Atghans right to chouse their own guvernment. and it bovcutts the Liv-sponsured peace talks because they include the Russian-backed Kabul regime (this does not stop Iran from keeping a large mission in Kabui). The Iranian government likes to hint that its long border with. Afghani stan and its influence with a lor of Atghans would enable it to saborage a deal it disapproved of.

The Russians cleariv rake these threars seriouslv. A Soviet official visited Iran just betore the Afghan peace negotiations resumed in March. The United Vations takes care to tell lran how the negotiations are doing. But Iran mav nor have the leverage it claims. It has given the Atghan guerrillas litrle material support, and not manv weapons get across its border. Fewer than 20\% of Atghans are Shia Muslims. and the rest do noe necessarilv admire Shia Iran. Nor do the Shias live in che miitarilv interesting bits of Atghanistan: near the capital. or the Salang highwav to the Sovier border. The "Atghan card" that Iran so orten hints at in the Gulf-war

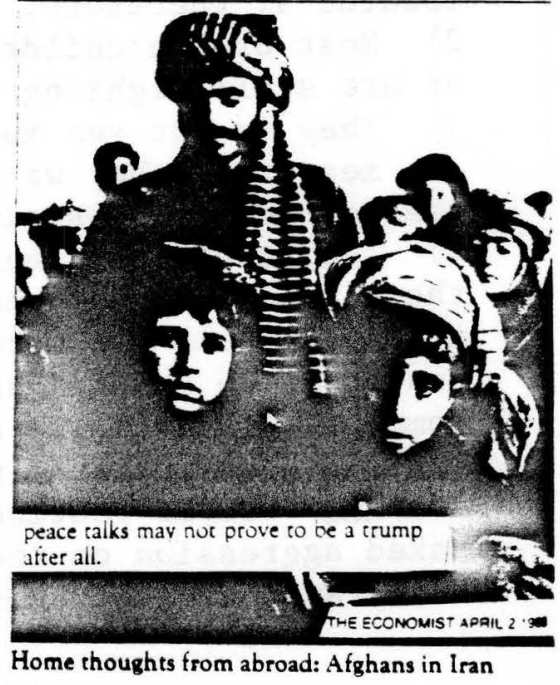




\section{REEENT PUBLJEATIONS}

"An End in Sight?" by E.W. Desmond in TIME, April 18. Pp. 34-37.

"Stingers Used by Afghan Rebels Stymie Soviet Air Force Tactics" by John Gunston in AVIATION WEEK \& SPACE TECHNOLOGY April 4. Pp. 46-48. (See p. 20)

The April 1988 issue of SOLDIER OF FORTUNE carries the following articles on Afghanistan: "Assignment Afghanistan" by Harry Bateson (how the US news media aid the KGB in spreading disinformation on the Afghan conflict); "Four Battles in Afghanistan" by David Isby (Operation Avalanche \& battles at Arghandab, Jadji \& Kalafghan show how the mujahideen are destroying the myth of Soviet invincibility); "Endgame in Afghanistan" by Louis Dupree \& David Isby (when \& if the Soviets leave, will the rival parties honor a negotiated settlement?); $\&$ an editorial on "Russian Retreat" by SOF editor Robert Brown. Upcoming issues of SOF will carry articles in Afghanistan by Peter Douglas, Jake Border $\&$ Mike Winchester.

"A Reporter at Large (Afghanistan)" by Eqbal Ahmad \& Richard J. Barnet in THE NEW YORKER, April 11, 1988 . Pp. 44-86.

GORBACHEV'S NEW STRATEGY IN AFGHANISTAN by Marin Strmecki, originally published in STRATEGIC REVIEW*, has been translated into Dari \& published by the Afghan Jehad Works Translation Center in Peshawar, January 1988. * Summer 1987.

The JOURNAL OF THE MIDDLE EAST STUDIES SOCIETY at Columbia University lists the following Persian language publications on Afghanistan: THE HISTORY OF THE EVENTS \& INCIDENTS OF AFGHANISTAN by E'teżād al-Salțaneh, 'Alī Qolī, Tehran, 1986; THE HISTORY OF AFGHANISTAN AFTER ISLAM by 'Abd al-Hayy HabibI, Tehran: Donyā-ye Ketab, 1984. Subscriptions to the Journal are $\$ 10 /$ year ( 2 issues) and can be ordered from the Middle East Studies Society, Columbia University, 1111 IAB, $420 \mathrm{~W}$. 188th St., New York, NY 10027. Institutional subscriptions are $\$ 20$.

"In Peshawar, Everybody Comes to Green's" by George Foy in ROLLING STONE, 2/11/88. "Spies, mercenaries, drug smugglers \& journalists all converge on a seedy hotel to conduct the business of the brutal Afghan war." Pp 75-86.
AFGÁNSKÝ ZÁPISNf́k (Afghan Notebook) is a new publication published by the Association Solidarnošc Afghanistan \& Wydawnictwo KONTAKT in Paris. This "International Magazine for the Support of the Fighting in Afghanistan" began publication early in 1988 and is edited by Jan Tesar̆ \& Bohumil Krčil. It is an offspring of the Polish quarterly "Biuletyn Afganski" and carries translations of various int' 1 reports \& interviews as well as original information from Czech \& Slovak sources pertaining to Afghanistan. The 120-page lst issue contains articles by Rabbani, Bennigsen \& Majrooh, reports on human rights violations, proclamations, maps, addresses of organizations, etc. For more information write KONTAKT - AFGÁNSKÝ ZÁPISNÍK, 42, rue Raymond Marcheron, F-92170 VANVES, France.

BY ALL PARTIES TO THE CONFLICT: VIOLATIONS OF THE LAWS OF WAR IN AFGHANISTAN, a Helsinki Watch/Asia Watch Report, NY/Washington, D.C., March 1988. 90 pp. \$8 from HumanRights Watch, 36 West 44th St., New York, NY 10036.

"Afghan War Horses: People aren't the only ones fighting \& dying in Afghanistan" by Hunter Penn, WESTERN HORSEMAN, January 1988. Pp. 32-39.

AFGHANISTAN: TAKING THE PATH OF RECONCILIATION is a collection of Najibullah's speeches published by the Gov't Committee of Press \& Publication, Kabul 1988. 173 pp.

"The Persian Literature of Afghanistan, 191178 , in the Conteyt of Its Political \& Intellectual History" by Ashraf Ghani appears in PERSIAN LITERATURE, Columbia Lectures on Iranian Studies, edited by Ehsan Yarshatar, published by the State University of NY Press, State Univ. Plaza, Albany, NY 12246. 562 pp. $\$ 19.50$. paper $(\$ 49.50$ cloth $)$.

IL TESORO NASCOSTO DEGLI AFGHANI

Lucia Serena Loi, il cavaliere azzurro, Bologne, 1987. 178 pp. \#16 in the series Quaderni del Seminario di Iranistica, Uraloaltaistica e Caucasologia dell 'Universita degli Studi di Venezia.

"Southeast Afghanistan \& the Borderlands in the Early Historical Period: Some Further Observations \& Suggestions" by Willem Vogelsang appeared in the NEWSLETTER OF BALUCHISTAN STUDIES, \#4, Summer 1987, ISMEO, Rome.

Continued on p. 32 


\section{BODK REOLEUS}

THREE WOMEN OF HERAT, Veronica Doubleday, Jonathan Cape, London, 1988. 222 pp. text + 19 color photos +30 pencil drawings by the author. $\gamma^{r} 12.95$.

Three Women of Herat is a delightful read. At the same time it is an important contribution to the field of Afghan studies. In it Ms. Doubleday relates how she developed close friendships with three Afghan women and their extended families. The narrative flows easily, yet every day chores, rituals, attitudes and emotions are described in minute, colorful detail.

The three women and their families were quite different, Miriam was a self-contained woman from an hereditary musician family that allowed her to visit freely the homes of her extended family and worship at shrines on the outskirts of Herat.

Mother of Nebi was reclusive and isolated because she had lost her rural support network and her husband kept her close to home in the city. She was popular for her improvised renditions of songs learned during her rural childhood, however, and was consulted for her powers as a diviner through voluntary spirit possession and as a preparer of amulets for curses and protection against the evil eye. These were unusual services for a woman to perform.

Shirin was the most outgoing and independent; a professional musician with her own women's band. She taught the author to sing in the difficult Herati mode and to master the intricacies of the daira, the Afghan tambourine. Ms. Doubleday was an apt pupil and ultimately became a bona fide-member of Shirin's band.

Veronica Doubleday did not go to Herat with the intention of exploring the world of Herati women. In 1973-74 she accompanied her husband, ethnomusicologist John Baily, while he conducted formal research. On returning in 1976-77, she decided she was tired of being an "honorary male" and chose to study music so as to participate more fully in the life of Herat. Needing no interpreter, she established rapport quickly and was accepted as a member of the families of each of her friends.. Her account, therefore, is intimate and personal and catches the infectious liveliness of the women, as well as their moments of pain and despair.

Most importantly, this work illustrates the importance of women's communities in Afghan society. Women's support networks such as those described in the book have broken down among the refugee populations. Those who are concerned with the reconstruction of Afghanistan would do well to pay close attention to Three Wome日 of Herat. The future stability of Afghan culture will depend, in large part, on reestablishing such strong women's communities.

Nancy Hatch Dupree

Durham, North Carolina

THE AFGHANS IN AUSTRALIA, Michael Cigler, AE [Australasian Educa] Press, Melbourne [74 Railway Road, Blackburn 3130], 1986. 163 pp. text +5 maps +41 photographs. $A \$ 14.95$ (US\$10.72).

Michael Cigler's The Afghans in Australia is part of the Australian Ethnic Heritage Series; the research was undertaken under a grant from the Commonwealth Schools Commission; its purpose is to illuminate Australia's diverse cultural heritage. The textbook style, therefore, is predictable, but a plethora of vintage drawings, lithographs and photographs are great fun.

The book is filled with more precise data concerning the attributes and feats of camels than most Forum readers will probably care to know. On the other hand, those 
with a penchant for trivia will find all manner of fascinating bits. Where else would one learn that Afghans helped build a $1,620 \mathrm{~km}$ fence to keep rabbits away from the settled districts of Western Australia? (p. 110)

More seriously, this work does succeed in documenting the very real contributions Afghans made in opening up the central part of the Australian continent, $70 \%$ of which is arid or semi-arid. The author speculates that without the Afghans and their camels development would have been delayed by at least 50 years.

Afghans participated in the initial exploratory expeditions and, as settlers moved in, provided nearly all the transport, supplying homesteads and mines with provisions and carting ores, wool and other products out to the coastal cities. All the important national projects begun in the late 19 th-early 20 th centuries depended on Afghan expertise in hauling supplies and equipment. These included the famous 'Ghan' the train to Alice Springs, a large 'Ghan Town' and center-point of camel hauling during the heyday of camel transport from 1860 fnto the 1920s. The author estimates that about 3,000 Afghans were involved over a 60myear period.

Those who have read May Schinasi's meticulously researched The Afghans in Australia (The Asia Society Afghanistan Council Occasional Paper $\#_{22}$, October, 1980) will know that all the "Afghans" were not from Afghanistan. The Australians were not precise observers of ethnic diversity. Any turbaned male wearing "floating costumes," as Schinasi quotes, with a camel in tow, was automatically dubbed an Afghan.

Probably most were from Afghan tribes living on "the floating north-west limit of the British Empire of India" (Schinasi, p.5). The first Afghans arrived in Australia in 1860 and large-scale introductions took place in 1865, but the Durand Line demarcating Afghanistan's eastern border was drawn only in 1893. Two reports listing the ethnic and tribal affiliations of contributors to the Perth mosque in 1905 and 1906, the peak of the camel era, indicate that a very high proportion were from Afghanistan, the North-West Frontier and Baluchistan (Schinasi, p. 5). But in addition to these Afghans there were large numbers of cameleers from such areas as the Middle East, Egypt, Iran, Sind, the Punjab, and even one from Malaysia.

Cigler emphasizes that the most important, lasting cultural contribution of the Afghans was the introduction of Islam. Some interesting excerpts from newspapers describe religious festivities, but for a meaningful discussion of Islam in Australia during this period one is better off staying with May Schinasi.

Quotes from newspapers do serve to illustrate the depth and viciousness of racial intolerance directed toward some Afghans. Although many applied for naturalization, none were awarded British citizenship in spite of their recognized contributions.

Motor trucks were introduced in the early 1920 s and profits from cameleering rapidly dwindled. Unable to pay the grazing fees, the Afghans sadly forced their animals into the wilderness to fend for themselves. Within about a decade there were an estimated 50,000 wild camels which were so scorned as vermin that the government actively encouraged their destruction; in 1935 a local police party shot 153 animals in a single day. Today, happily, these "Skyscrappers of the Givvers," the uniquely Australian version of 'ships of the desert,' are enjoying a come back in the tourist business and as profitable exports to North Africa and the Middle East where they are prized for racing. They even make prestigious gifts. The Australian government sent four wild camels to King Khaled of Saudi Arabia in 1975, accompanied by Sallay Mahomet, son of a Kandahari camel driver who had arrived in 1897 and married a French woman.

The original cameleers had come alone; their contracts specifically forbade them to bring women. Some married local European or Aboriginal girls and their families gradually assimilated, moving into cattle and sheep breeding after the passing of 
camel transport; only a few maintain even scant interest in their backgrounds. The lone men took up droving, fencing, odd jobs with the railways, or tur ned to hawking and merchandizing. Many were lost in the crowds of the cities.

From the 1950s onwards, numbers of Afghans studied in Australia under the Colombo Plan, forging links that would stand them well during the tragic 1980s. Apparently some 2,000 Afghans have resettled in Australia (Refugees, \#46, October 1987: 43). A statement by a member of the Dept. of Foreign Affairs \& Trade, Canberra, reported that in $1986 / 87,450$ places were allocated for the resettlement of Afghan nationals, and "it is expected that a similar number will be resettled in 1987/88" (Afghan Mujahideen Medical Journal, Canberra, vol.2, \#1, January 1988: 3).

The sequel to The Afghans in Australia is in the making.

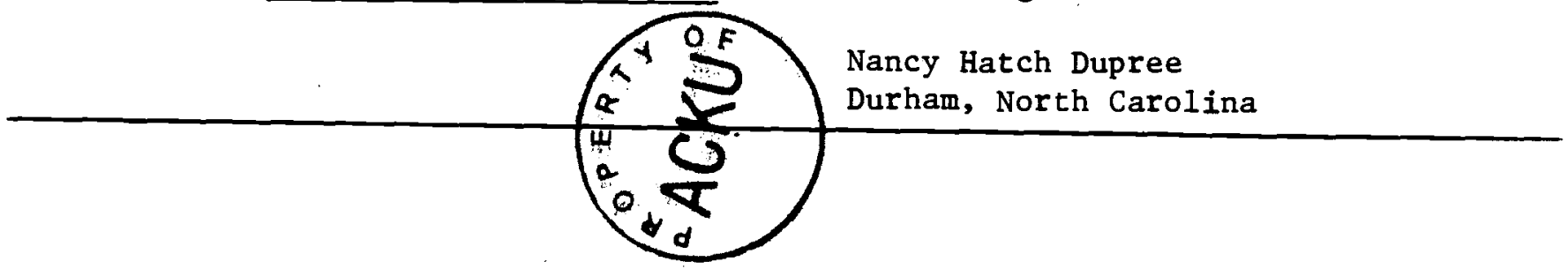

Recent Publications - Cont. from p. 29

"Afghan Refugees in Pakistan" by Louis \& Nancy Dupree in WORLD REFUGEE SURVEY 1987 IN REVIEW, published by the American Council for Nationalities Service, 815 15 th St.,NW, Suite 610, Washington DC 20005. 84 pp. \$8. The volume also has a directory of refugee organizations \& a bibliography.

TÉMOIN IN AFGHANISTAN, published in France by Stock, is a collection of photographs taken by Alain Guillo, the French photographer currently serving a 10-year sentence in a Kabul prison for "illegal entry \& spying." The texts accompanying the color photos are dedicated to Guillo \& are written by J. Abouchar, H. Amouroux, Ph. Augoyard, P. Bruckner, G. Chaliand, A. Glucksmann, M. Halter, Y. Jouffa, B. Kouchner, J. Lacoutre, B.-H. Lévy \& G. Perrault. March 1988. Ff 150. ISBN 2.234-02115-4.

THE TRAGEDY OF AFGHANISTAN, edited by Bo Huldt \& Erland Jansson, London, Croom Helm, 1988, is divided into 5 parts: The Country $\&$ Its People. articles by Louis Dupree, Nancy \& Richard Tapper, Roger Christensen, Richard Frye \& Eden Naby; Afghan Learning \& Education articles by S.B. Majrooh (to whom the book is dedicated), Bo Utas, 01ivier Roy \& Batinshah Safi; The War, articles by Jan Ovesen, Jan-Heeren Grevemeyer, Reider Gronhaug, Moh'd Eshaq \& Sabahuddin Kushkaki; Ecology, articles by Terje Skogland \& Moh'd Qasim Yusufi; The Exile, articles by Inger Boesen, Bernt Glatzer \& Nancy Dupree.
THE IMPAIRED MIND is published by the Psychiatry Center for Afghan Refugees, G.P.0. Box 641, Peshawar. Pakistan. Contents include case histories, statistics, descriptions of various mental disorders afflicting refugees, etc. Illustrations, graphs.

HUMAN CONCERN NEWS, published by Human Concern Int'1, Box 3984, Station C, Ottawa, Ontario, Canada KIY 4P2, appeared in January. The 4-page tabloid-size publication describes the organization's work in Afghanistan \& other areas. The organization has also published an 8-page "Afghanistan Crises Overview."

Dye transfer color prints of scenes of Afghanistan are available from Luke Powe11, 230 Battell Block, Middlebury, VT 05753. Cards with envelopes are $\$ 6$ per dozen, $\$ 35 / 100$.

Eng. Sayd Naim Majrooh has taken over the running of the Afghan Information Center in Peshawar. The son of Syed B. Majrooh, Naim was born in Kabul \& graduated from the Kabul Polytechnic Institute. He joined the Kunar resistance in 1979. For the past 7 years he worked as a liaison officer with the ICRC in Peshawar. The AIC Monthly Bulletin is available from the AIC, G.P.O. Box 228, Peshawar, Pakistan. Subscriptions are $\$ 50 /$ year.

"Afghan Aid: The Role of Private Voluntary Organizations" by John Lorentz in the JOURNAL OF S. ASIAN \& ME STUDIES, VoI XI, No. I\&2, Fall/Winter 1987. 

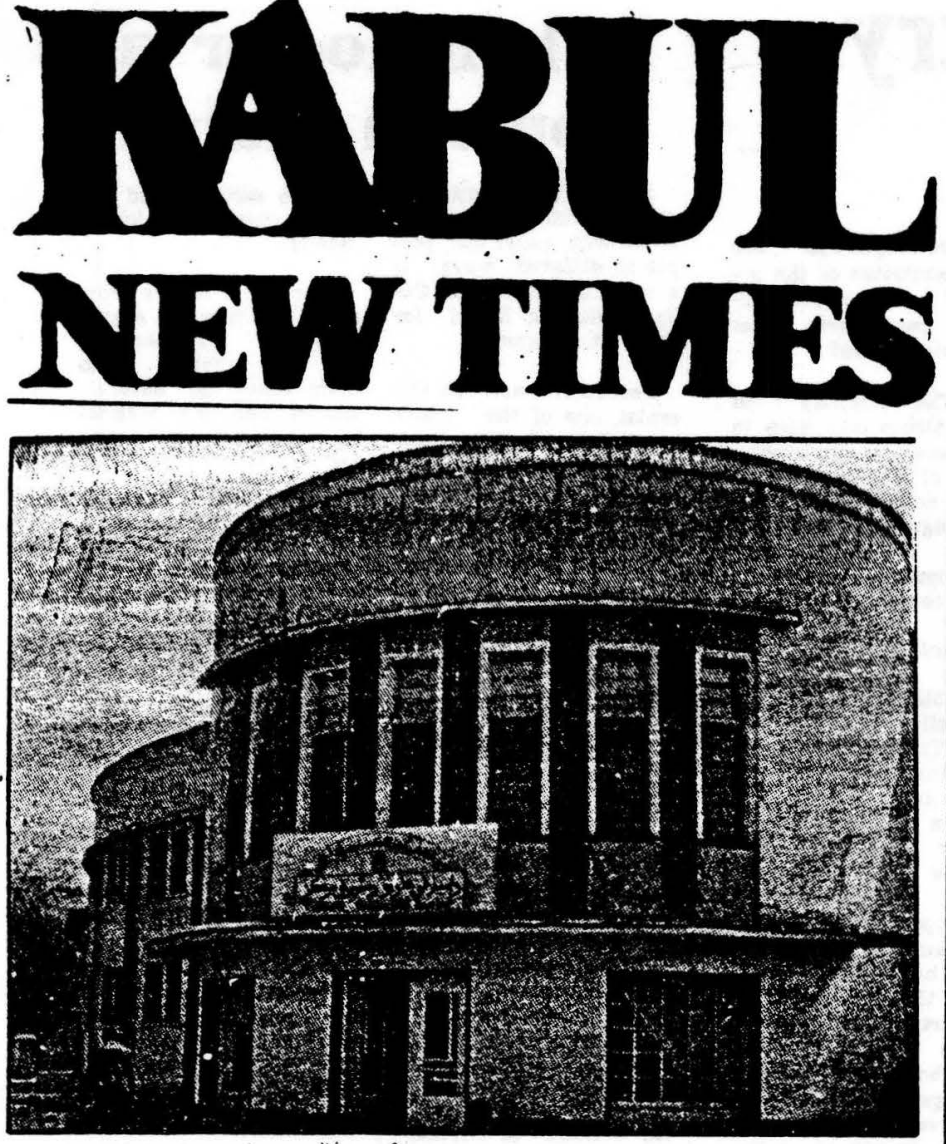

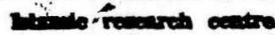

(Phote by Resa)

\section{Activities of Islamic Studies Centre} religion of Islam by the
"We hive witnesied th- Stidies Centres of other at during years of the ro volution keea attention bas been paid to sacred party and state. Beadde other effective measures for the establishment of Islamic Studies Centre have been taken in the year 1365 (1986)," said Islamic Studies Centre.

"For the firat time in the history of our coun try the Centre was set up with the all-round as sistance of the revolutionsty state. Among its ary state. Among providing facilities to researchers and atablishment of rel ations with the Islamte
Islamie countries" be added.

"At the Islamic Stud. ies Centre seven titles he flelds of Islamic philoso phy, history, eivilization, and interpretation of Islam: Also, research is continuing on 20

"The Islamic Studie Centre has established contacts with the Socialist People's Libyan Ar. a Jamahiriya and Iraq. These organisations are being assisted by the Alghanistan Islamic Studies Centre through sending of publications and Islamic books. ve been published in the

"Islamie Studies Cem tres glves all asdistance for the comprehenative research in this sphere to scholarz. In this connection department of law and philosophy, in terpetation of Prophet's Sayinga, belief, philosophy and Islamie bistory have been set up, and number of researchers to ained for the year1367 (1988)," he concluded.

As a result of attent lon of the party and to. vernment of the Republie of Aghanistan hope this centre will be transformed in the near quture as a bis remeareh Centre among the Iala. mic countries.

$2 / 14$

\section{TENDER NOTICE}

Mohammad Ehsan president of Farl Ehsen company Lid. bids to supply three items, as per specifications, at a total cost of Afa 92000000 .

- 2,500 thread, Indian colour, 200,000 bobbins, each Afs 790 .

- Horny button Indian overcoat colour. one million, each Afs 4.

- Horny button for trousers and coat ter million, each As 3 .

Individuals, institutions and the agents of the foreign companies willing to bid should attend the bidding at the procurement department of the Ministry of Defence, located at the Darul-Aman at $10 \mathrm{~cm}$ on February 22, 1988, which is the last date for bidding Terms and condittons plus sample can be obtained, bidbond in cash. Commeredel licence, bill and invoice are required. (176) $2-1$
Tel: e184t

Daltorid Dour

Tol: o1es

Ciruelatten: enes

Adares:

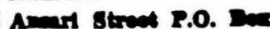
ress rabal

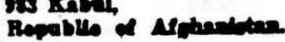

\section{KU doctoral programme}

INDUL, MARCA L. Pastos Language and SU, weach eandidate wid (BIA) Literiture, Physica Ge have an seadenis advis

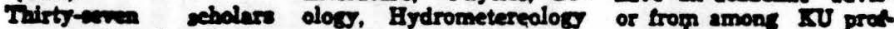
have apolind for doctors A ronomy. National Do 1. Tobel Univeraty this reas. The univerity acters doctoral decrees in Phi Josophy. Modern Michen Hitary, Wedt Binters.

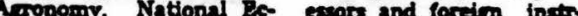
onomic Planning. Pay- uetors. Also, each ean chology, Public Low, didate will be provided Dari Language and : with an oppoctunity Literature, Journalism continue his or be rese and Politieal Beonomy. areh propremen sto pecording to a wurce of ad."

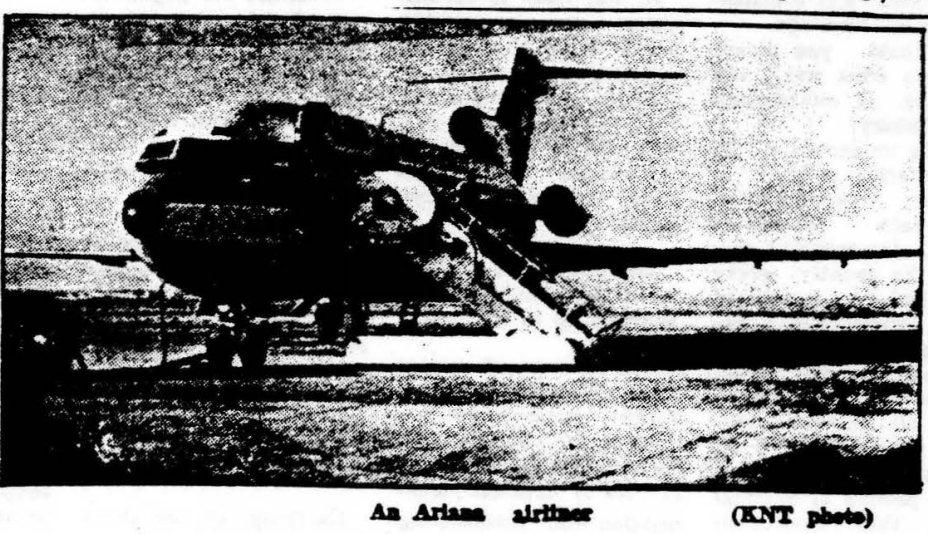

\section{Ariana Airlines exceeds plan target}

Ariana Afghan Airlinea carried 217,000 passengers and 6801 tons of cargo on its domestic and interna tional flights

A spokesman of the $\mathrm{Cl}$. vil Aviation Ministry st id that the Airlines had carried 6825 passengers year.
Thirteen experts of the ghts and gers on the domestic atghts, which is 18 per cent more than the plan and shows a 28 per cent inc rease in cargo transport and 18 per cent increase in passenger transport ow year. triendly country Sovie Union and 250 Afghan ex. perts are working in the moders workshop of the Rabul airport

The Civil Aviation Mi nistry bas 12 planes in its $\sim$ fleet for domestic and international flights (BCA)

\section{How art critics function}

\section{Autho}

Trector: Nasir-Al-Kash The short film 'Qab' (a picture trame), seree aed last Sunday was a pr. oduct of intelleet. In short time of just five minutes, the $1 \mathrm{~lm}$ deseribes the basle problem fac ed by litterateures and art eritice which forms its theme.

A brief review the film will elucidate thls point. A young woman painter bolds an exhibition of her works and Fditorin. Chief of a dally assigns the head of the cultural section of the daily to wr. ite a critlque on the wo rks. After returning ha me from office, the head of the eultural section looks at all the magazines in a bid to find an article bout the art and personality of the artist but be is not successful. He feels helpless. He has Keard bout the beauty of the painter that makes her paintings look more beautiful.

The painter is distres sed at the attitude of the eritic. The exhibition opens and art lans crowd the gallery. When ill sp ectators walk out of the hall, only the crittic remains. Instead of paying attention to the paint ings, he stands there wth his eyes rivetted on the painter.

Glances are exchanged between the critle and the artist who pretencis to be interested in him. They walk out from the ex. hibition hall for an interv. lew, go to a place for re creation and become close. The film ends with an exhibition of two pictures of the girl and the critic hanging - beside other tableaux in the ball. The end of the fllm, in lact. is its essence. The short film shows the state of art and art critics in our country. The cone lusion drawn from. this film. Is that the crities in our country base their writing on personal rela. Hans mether than on scieIntifle, artistic and litera. ry norms and prineiples. It is a lact that some eritles are greatly influenced by groupism and personal affillations In such cireumstances one can imagine the signific ance of eritics in correct. ly guiding the art and $1 \%$. erature in the country

(Famid Mehrnas)

\section{Rare relies housed in}

\section{ethnographic museum}

Over $\mathbf{8 0 0}$ historical and cultural relics which de pict the old times and etvilisation of the people of Afghanistan are on display in the ethnographic museum located in Koti Baghcha in the capital. Historieal relies inclu- ding costumes, jewellery, old fumiture, arms hunting equipment and cultural artifacts are arranged in eleven booths.

The relics which belong to Pashtoon, Hazara, Tajik, Uzbek, Nooristani and Turkman nationalities and

the Hindu community are separately arranced ace rding to the general dir. ector of the mureum.

He added that though all museum object we re valuable the oldest and ratest relies were Noor. istani wood carvings. 


\section{Key role of ministry Cuban doctor at of nationalities home in Kabul}

\begin{abstract}
the activity of his minit try which was constitur ted some time apo.

Q: Would you pleane elvediece what was the the Minimiter?
\end{abstract}

Following is an interv- documeats of Loja Jirs. tew with Mohammad an and the constitation Akber Shormach, Mini- of the Bepablie of As: ster of Nationalities on hanleten?

A: To implement the humanitarian policy of national reconciliation and reach nationwide $c *$ In the country grave takks had been assigned to the Miniatry of Natio nalities and Tribal Alfairs that, necesaitated extensive work and attract ion of all fraternal tribes and nationalities for their active payticipation in the process of national accord, their mobilizatjon around the revolutionary government. The $\mathrm{Ce}$ ntral Committee of the PDPA and the Council of Ministers therefore approved the extablishment of Ministry of Nationalitiea.

Q: Could jea explets the back discetion of aletery to the botut of the
A: The tasks of the Ministry are inseparably linked with the implementation of the policy of national reconciliation. with active participation of fraternal nationalities under the peace progr: amme.

The duties and activitles of the ministry ar summed up as follows:

- Expansion of various mass activities among diIferent nationalities regiding in the country for further accelerating the ciliation and maintaining nationwide peace. unahakable unity and solonalities;

- Study of national, hitotorical and cultural characteriatics of dilfere nt antionalittes.

- Identifying the neeprocess of national recon-

- Struggle for ensuring ds and demands and for- trs wis reenen to the mulating proposals of implementatice of the po various nationalities in lley of aatlonal. reconell-
different fields.

- Elfort lor pypularie ing. developing and enriching the culture. language and literature and other values and traditjons of nationalities.

Consistent and iruitful political work amo ng nationalities.

- Struggle against the attempts of enemies who want to intensify hostilities, and ethnic and tribal discrimination. Efforts for creation of objective conditions for guaranteeing the rights and equality nationalities.

Carrying out the above tasks would create objeetive conditions for equality of rights of nationalities. consolidation of unity and coherion among the fraternal peoples of Afghanistan and finally solution of national isaue.

Q: Fow do you ovalus. the role of the Minis. Its secend phanes?

A: The Ministry Nationalities was born in the course of implement ation of the peace programme and certain task are asaigned to it for $n$ alizing the objectives of the programme. For inst ance; convenine of triba jirgahs, meeting elders and infuential social tigures and explaining the noble aims of the pe ace polley are our prime tasks. To date the jirgahs of Nooristani, Pashaie. Uzbek and Turkmen have been held in which ne cessary decisions were adopted for attracting broad mases towards the people's power. pesce and tranquility. To ore alities the proposals of the participants of the jirgahs were collected and submitted to concern. ed organs Also speetfic measures are taken for further growth of culto re, language and litere ture of nationalitice anize better work in loe

\section{PB decides to}

YABULL MARCH. (BIA)

the periodic sescion of PDPA CC was held on Thursday.

The Politburo reviewed the realisation of the policy of national reco sellintion and considered reneralization of the party's policy of respect to, observance and preservation of the sacred re ther development of education and rese education in the prineples and tenets of Islam. training of scientlfic, professional cadres with hicher education in the telds Islamic education ciences, law and justice, teaching of Arabic and establishment of an Islamic omotion of studies and researches in Islamic sccences in the country. The Politburo directed that the Inlamic der the Ministry of $\mathrm{Hig}$ ber and Professional rdueation based on ibe faculty of theolo and the center for Islamic tudies.

The Politburo recommended to the Council of Ministers to promote the Islamic University and also entrusted tasks to other responsible uthorities for starting the university.

The Politburo also conudered the military patrlotic training of youth.in the conditions of realisat. ion of national reconcillatton, and noted that there otill exist serious de cects and ahorteomings in this field and that military commissariats do not take active part in it.

The Politburo, assessed as poor the contribution of the DYOA committee and organisations to the military-patriotic traini$\mathrm{ng}$ of youth and criticized the activity of party com mittees of the Ministrie of Education and Figher and Professional 5d. ucation and mass media in this work

The Politburo passed - resolution on improvin matters in the above. adopted necessary decis ions on the recruitment to military service and reserve forces of activis ts and propessional cadr es of the PDPA, social organisations, publication organs of the PDPA and party members in state organs who are eligible for service.

The Politburo discuseed the strengthening of the political and party
It also discussed and

Among the internationaliat triends of Atchas. gtan who asaist our peo ple in different way is medical team trom Cu. ba servis: in Kabul 10 the past six manths.

Peodro Alfonso, an int emist one of the mem bers of the Cuban team wes all enthusiastir ab out his work in Arghan istan when your correspondent met him.

"Our group of edght members arrived in. At ghanistan six months ago and would sta here for two years to serve

"Though Afghanistan and Cuba are far apart geographically, our hear. ts are close", he added.

"The Cuban people follow the events in Aighanistan with great interest and rejoice in your vioto ries. When we were asked who would go to Alghan-

\section{appointments}

Nafibuilish Masir. ciles representative of tor the nother ces with the rank of De puts Prime Mindeter.

Feda Mohnmmed Do

\section{set up Islamic univ.}

leadership of youth and ng the youth. Many PDthe elevation of the role of party and DYOA committees and organisatio ns in this connection. It pointed ant that still all the youth cannot find employment according to their profession and liking. Enough attention is not paid to the protection and sound upbringing of children; a large numb ex of young peasants stunaware of the new agrarian policy, and thus have not benefitted from its advantages.

The Ministries of Edu cation, Higher and Professional Education, and 


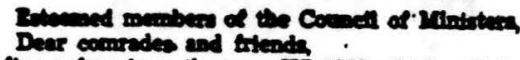
Are 2 low days, the year BS 1306 wheh will be

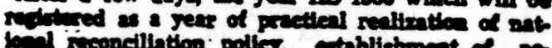

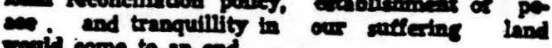

It should be kept in view that the current year shows a rise in the level of activity of our political and state leadershis in the inter national arens, particulariy conativictive initis. tives have been set forth for the political

The itatements of Najibullah. President of Alghenistan and Mikhail Gorbachev, CPSU CC General Seeretary on Afghanistan enjoy great importance for restoration of pecee in our country. All obstacles created by Pakistan with regard to the peaceful settlement of the problem of Afgr anistan and signing of Geneva agreements have been practically removed with these statements During this year, enormous measures were taken to promote the living standards of the people of Alghanistan. The salaries of the personned of armed forces have been increased. The salaries of soldiers have been raised from 5 to 10 timea. The military stores where the personnel of the armed forces and their tamilies can buy foodstuffs and indistrial products at low price bave started functioning practically.

State assistance to food allowance of governm ent employees has been increased one and a half times. The tree distribution of llour, wheat and edible oil to state workers and employeen. disabled veterans of revolution and wort as well as the families of martys against cous sand coupon holders receive $56 \mathrm{~kg}$ of nour of wheat and six $\mathrm{kg}$ of edible oil.

Extra salaries are paid according to elimatie and regiona conditions to state workers and employees. Taken these as a whole, around four $\mathrm{mi}$ llion citizens of the countsy have enjoyed these fa cilities." This is considered one of our greatest $2 \mathrm{ab}$

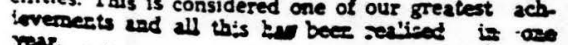

Some of the dath and ftroures concerning the realization of socio-economic growth of the country during 1987 are put as follows:

The assessments show that the groes rocial product increased during 1978 by Afs 3.7 billion
or 2.4 per cent and national tacome by Afs 2.4 or 2.4 per cent and national income
billion or 2.3 per cent respectively.

Definite positive achievements have been made in various apheres. Gross agricultural produetion during 1987 ahowed a growt th of 0.7 per cent compared to 1986. To raise the effleiency of agriculture, the govermment has distributed 155 thousand tons of chemical fertilisers and Afs 105 million worth of pestiddes to farmers. Peasents have also recelved Improved wheat. cottion and sugarbeet seeds. Mechanized agricultural imple
ments are greatly utilised.

As you know, this year we devoted much attention to wheat proeurement. The purchase of wheat reached 170 thousand tons This level of purchase has been recorded for the firit time in ieved in the products of coal, cement, bricks and gravel. The production of power, wood, light indu. stry and foodstuffs have been stepped up. ...

One should say that besides fall in the produce tion of cotton goods tit quality has also not impa oved. The idle time of gin and press factories and non-utilisation of their capacities due to lack of cotton are greatly increasing. In the firgah of cotton growers which was held recently, we announced some measures for increasing the intereat of peasants in raising production of this $1 \mathrm{mp}$ ortant industrial crop, that is cotton. But to realise all the predicted measures aimed at incree. should utilise all the posibilities.

The Ministry of Delence has not executed it plan in dress production, the Interior Ministry in furniture production the Ministry of Commerce in processing walnuta raisin and product veretable preserves would probably be not realved.

Apart from their material value, the fall in their production means not ensuring the supply of essential gonds to the production in industrial private sector is assessed at 94.4 per cent during the current year. The main factors for such a state of affairs are lack of acoess of private enterprises to material resources, particularly raw material. to make use of their production capacities...
The ministries and departments must tabo ceninite mensures to overeome' the defects in the pdustarial field. The plan of HS 1307 places new and cerfous tasks before un. The overall growth of

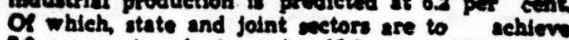
if per ont, prtvale sector 12.5 per cent and dierafts 2.4 per cent

In this way, production of power will tnesenen by 5 per cent, of construetion material by 7.2 by cent, machine products and iron emelting by 23.2 per cent, ilght indurtery by 25.8 per cent and

Taking into eceount the limitation of eurrincy emde in HS 1307 foretim exhanee for the develo ment projects has been predicted at two times ountrin in 1987. The assistance of friendly ountries and international organisatons is used as for the development projects.

The total volume of foreign assiatance for is 1367 figures out to 223.3 million dollars which 1 14.5 per eent more' than in the previous year.

As in the past, a major part of this assistance that is, its 97 per cent comes from the Soviet Union Fnd CMEA countries. The share of Soviet Union decouts for 81 per cent of the whole assistance. It as necessary that a number of defects and hardso wation of 1988 plan should be pointed out. Some wation of of great importance have been entered - the plan without the comblete technical doeuante or without protecols with the concerned surees.

\section{THE STATE BUDGET:}

The report presented by Mohammad rabir, Minister of Finance on implementation of the state budget in the HS 1365 and the review for HS 1360 as well as the dratt of the budzet for the new year 1367 together indicate that special work has been carried out by the Ministry of Finance, other ministriea, ofrices and muniespalitles in attracting ineome to the state budget for financing various socio-conomic projects aimed at promoting the living condition of the people. Special allocation is made in the budget of the current year for realization of the poliey of national reeoneiliation.

During this year special concessions were made in tax payments by repatriates and residents of remote area of the country. The salarles of some categories

Similarly, some other necessary measures we re adopted during this year. All these needed additional financial resources in the eurrent year. A thorough review of the implementation of athis yasr's besiget iadicates that despite the effort made for its realization there existed dirzeulties and problems caused by objective factors Part of these shortcomings resulted from the defects in the work of some ministries and offices, which did not discharge their budget tasks on time. Similarly they did not observe economy measures in spending In order to realize the tasks pertaining to increase in budget revenue and reduction of expenses on low priority sehemes the Couneil of Ministers adopted its special resolution No. 277, dated Jaddi 9, 1366. It was envisaged in the resolu. tion that necessary measures should be adopted for realization of the budget plans and reduction of expenses in various state institutions.

It should be pointed out that some of these problems will be carried over to the next year. problems will be carried over to the next year. in the supply of gratis aid which is carried thro ugh military stores. The ministries of commerce, defence, interior and state security need to impr. ove their work in this connection considerably. They shall delive

The Minister of Finance, Mohammad Rabir, shall intensify the work of tax collection and to enterprises, institutions and individuala.

Another reserve exista for increasing the state budget in the new year.

I would like to point out that due to difte ultles, the state income decreased by 6 billion Als because of the fall in the extraction and supply of natural gas. Nevertheless it is envisa. ged that the income in the state budget for next year will increase 12 per cent from domestic sources and 8 per cent trom foreign sources as
compared to the current year.

In the draft of the HS 1307 budget, for the Airat time some income is anticipated from volum tary loans in order to rehabilitate those branches of national economy which have been damaged during the war. The state has attached great hope to atato loans in order to reactivate the national ceonomy. It is necenaer that this nennomic meas ure becomes a rood example for mobillation of all trata of the people of Mighaniatan ineluding Torkers atate emnloyece Densants. Craftsmen. intelligentede, private exterpreneurs and traders - 0 that they revive our ceonomy which has been damaged by the wax. This will contribut to restoration of mompues sebools and bealth to trea The organisation and execution of this voluntary and important meavers outs important talks before the Manistry of Yinance, the De Afehanistan Bank as well as other ministro

The exvenditure in the state budget for the year HS 1307 despite ecosomization will increase by 18.25 per cent as compared to 1368 .

In the next rear's budset additional expendtture bas been envisared for finaneing the mintatres, otfices and new

similarly additional. exponditure ts envisaged In the budget of the new year to tinane ans lites of martitss and the bandicapped. Plepayment If the credits given by other countries bas also been taken into conaideration. Similariy, expe diture reimbursment of the coot of coupon items has been Inereased conidderably. For the first time in the history of the country. apectal expenditure is allocated to those families twose plen of 1337 to distribute tree uniforms and atal lonery to school studenta The monthly allowan ce of the university students will be supplied free breakfast. In order to fulin these tasks a total of 3 billion Afs has been earmariked. It is reouired that the ministers. preoldents tees should supervise the economisation measures which are to be adopted in the state institution

Durting the laat two years as an experimental measure loeal budgets have been olamned for wait to see their rexults. In our vifw this experiment was successful. $A$ toral of 4 billion Ass hes been allocated for 29 prownere. Kabul eity and the Khost division of Paktia province in HS 1367.

Out of 24 state indtitutions 24 per cent of them belons to six ministries: 12 to ministry of stuffs 5 to ministry of agricultur and land roocm one to miniatry of power energy, one to ministry of construction affairs and one to ministry of mines and industries. All of them function below self. cufficient level.

The leaderahio of the mint thy of trensport justifles lack of celf-nurneleney in the transport institutions due to lom tariffs for dellvery of goods Howerer the covernment tating ino ceeount the objective factor raleed the tarilf by two times, but still the vehicles are kept for long periods loaded, they are parked for nspotted only from one side and finally the improper utilization of parkdng lote altogether have contributed to lack of selfoufficiency in the transport sector.

As a result, it could be stated that it is not the low rate of tarriffs on dellivery of goods which be sought in the organieational work of these enterprises. Another reason for the low level of self-sulficiency in the state enterproises is that many. of them have become used to receivin state subsidy to compensate their detletts. Thus they never work at imptowing the state of affairs in their enterprises. Every fourth one
of the state enterprises fumetions below selfsufficiency. Such a state of affairs cannot be permitted any more. Reocolute measures should oufficlent and are able to finnce themselve.

Ol course it is not an eary matter, it requires or course ilsion by the related. miniatry, ofsceer, state planning committee, the ministry of finance and the Da Afghanistan Bank. They should simolify and improve the system of mutual reaponsibility towards state budget and resularly repay their loans from thelr proflta. They abof surplus profits in the enterprises and should add to the revenue of the collectives This will improve the economic accounting will strenrill improve the economic acco the economy in seneral. 

ceatre and the local organs. and to promole the prestige of the council of people's deputien the counel of ministers adopted the resolut lons No. 169, dated Aqrab 27, 1365 and No. 134 Q Saratan 20, 1383 endorsine the organisattonal strectures of the executt ve committees of netls of poople's deputies in the provinces. The new organiagtional structurs is based on demoratte centraliem. It has a dual character. That mean the state offices in the provinces are aubordinate to the executive committees as far as theis budget plan, employment and relief of cadres, budget plan, employment and relief of cadres, neerned. At the same fime these offices are and institutions in the provinces are subordinate to the concermed ministry or central administration in Kabul from where they receive practical assis tance, and their general policy. Nlso the cen tral administration trains their professional cadres.

Similarly, in order to create a unifled system for appointment and relief of cadres the Council of Ministers adopted resolution No. 95, dated Jawza 19. 1366 entrusting special powers to the executive committees of the provinces. Accordingly the provineial executive committees have the authority to appoint or relieve state cadres upto rank three. Likewise, the provincial executive committees have the authority now to appoint or releive the governors of districts and subdistricts

The duel system has been ensured in most of the provinces. The assessments made of the implementation of new organisation based on democratic centralism and the dual subordinate $5 y-$ stem Indicate that certain order has come into being in provinees, the relations of the eapital with local organs have improved in localities and chaos in this regard have been prevented. The centraliam of administration has shaped in the executive committees and caused the elevation of the role' and authority of executive committes of provinces.

The executive committees of provinces have not yet realized the division of power with the opposition forces as if is necessary, and paid less attention to the creation of the nuclel of sub-districts and districts.

Establishment of contacts with the opposition groups for their joining with the state power and or conclusion of protocols are poorly conducted. Necessary use is not made of the possibilities and the role of individuale in stopping armed activities of the opposition groups. Adequate use is not made also of the possibility of drawing opposition group n localities in activising the administrative units and villages that are not under state control. It is necessary to act with courage,

One of the main issues in the process of the policy of national reconciliation is the retum of emigrants. Specific work has been aceomplished. and there are good gains in this regard too. To manage and organise the affairs of repatriates and to give them befitting welcome 22 Prontier reception centres. 22 peace guest houses and 10 peace townships have been set up. The total number of repatriates exceeds 120,000 . So far - larre number of revatriates have been employed. and their children admitted to schools.

Direct ties have been established between 29 provinces. Rhost division and Kabul eity with the republies and cities of the Soviet Uniom, and cooperation protocols involving over 70 million rouble assistance, have so far been concluded.

The planning commissions of provinces abo uld make effective and all round use of all theee possibilities and arsistance rendered to the $A P$. Rhan provinces acending to the protocols direct coopmention signed with the republies and provinces of the Solvet Union, for complete ful. fument of plans of soclo-economite development

Dear comrades,

The plan of socin-connmic develooment and the state budget for HS 1367 (beginning March 21, 1988), have placed before us great tasks. But alone sufficient if all ectives and tasks are not atone sufficient if all existing possibilities are not Utilized. and accurate and practical work organized. Our main task begins just today, that 1, to soecity the tasks envisaged in the plan and budget for the concerned organs and to search weys leading to their realization.

Confidence can be expressed that the gover nment members would exert all their efforts plan and bing the tanks envisaped in the state is a conerete contribution to the rhich in itselp the policy of national reconelliation in then of try.

3/10 (RTA)

\section{Valuable service done by Ulema's}

"Over 35,000 ulema, cle rigmen and imams of the country are organised in the high counell of ulema and clergymen. The counell renders valuable service for the improve ment of thetr lile" asid Mawlaw . Ghulam Sar War Mansour, chatrman ema nit cletein of us the Republic of Asthanitan.

"The counell to a relis: Lous and reetal organit. atton. It was extablished in 1980. Eighty one permanert members 23 me mbers of the executive ca mmittee and five members of supervisory committee were elected in the thind conference of the counell which i of held in 1980.

"225 reeldential apart. ments have so far been disterbuted by this cotsneil to elergymen and ulems of the country in the Mierotayon. The sa. laries of viema and clen crmen have been ineresand and these figures are now enjoying the coupon putvieges.

About 400 to 900 ule min and clesgymen trom different provinces of the country are sent ab road every reas for ex hanging : views with ule im and clersymen of It

lamie coustined.

The coundirihas eatab-

\section{high council}

milar institutions in the Islamic countries. By sending letters and messe es on different oceasions and religious days it consolidates its relations with similar counetls in these countries

"Tortyseven ulema and clersmen are mobllised in the commiation for natlonal resoneilfation of this council. They have

gone 97 times to 27 provinces of the country to explain the holy religion of Islam and the programmes of national recone illation Over 31,000 pue blieity leaflets have so fas been distributed by this commisaion in the rubd commission in the rubd. provinces of the country. 215 letter

\section{Thentre:}

\section{Rashid Latifi led the way max is}

Abdul Rashld Iatta who lounded the theatro in Afghaniatan had trai ned a large number. of talented youth and oryan ired. for them courwes in acting. Such well know Mashal Fonaryar, Ham Id Jalla, the lat Uatud Raflq Sadiq, Naim Far han were amons hls dis ciplei.

Besides being the fath er of Aghan theatre, Re shid Latifl was also writer, who wrote for his people.

The tirst play staged in Afghanistan was writt en by Abdul Rashid Lat ift. Later his other play iike 'Sllver chandeller? 'Miserable life' and ' $\mathrm{H}$ is not my father wer also staged. In 1943 ho was appointed director. to the theatre brought about drastic changes in theatre.

Rashid Paya, head of the theatre section of the Union of Artists said. "Latifl ised to write. de cornte the stage, direct plays and tried to keep the toreh burning bright during the time he was responsible for theatre in golden age of theatre and this art developed deep bands with the people."

Wall Iattl, actor and director of clacme and - nepter of Rashid Lat IfI any: "My uncle Latif hed links with boch thestro and etreme. Ho alw ays displayed innovithons and initlatives Ho also cerved

The magasione 'Green leaf,' a publication of the then bouse of destitutes and Selya, a magaxine in Arable which Latift pubHised in Cairo when be was the press attache of Alghaniatan in Egypt are examples.

The firat Afghan $\mathrm{nm}$ called Tove and friends. hip' was made by him in India with the collaboration of some other direct-

or. Wall Latin added: the first work wittes by the late Rashid Latift was called 'Exoert of the hall' and his last bier was 'He is not my father.' Latifl used to translate plavs from Russian. Arable and French. direct and stage them. Dying of

lung cancer in the last slated Gogol's 'Gown'" Abdul Rashid Latill died on Juae 11, 1965 when be was only 52. Wall Latifi recalling the past, said: "I was stlll a minor when my uncle Initiated me into acting. I played my fir st silent sole on the stage Later tragic, comic and romantic roles were also dven to me. I scted in plays from my seventh standard upto the gradu ation from Kabul Univer sity, that is, 13 years. was also included in the sent to the Soviet Union for study in cinematorsapiny at the initiative Rashid Latifl. I studied cinematography in the years. I became film director, above all. due to the encouragement. received from my great tied.

'Difficult davs' was the 